\title{
A Coasian boundary inquiry on zoning and property rights: lot and zone boundaries and transaction costs ${ }^{1}$
}

\author{
Lawrence W.C. Lai*+ \& Stephen N.G. Davies* \\ +Ronald Coase Centre for Property Rights Research \\ Correspondence: wclai@hku.hk, daiwaisi@hku.hk \\ *Department of Real Estate and Construction
}

Faculty of Architecture

University of Hong Kong

30 May 2016

\begin{abstract}
Coase's (1960) famous story of land use conflicts between two farms, as generalized in the Coase Theorem, injects into neo-institutional economics a potential to overcome the a-spatial limitations of neoclassical economics and contribute to theorization in planning as a science for delineating places for specific purposes, or zoning. In the light of the historical evolution in spatial division of labour and a review of the literature on the definitions and meaning of zoning, this exploratory interdisciplinary inquiry informed by neo-institutional economics, history of surveying and planning, attempts to use the corollary of the Coase Theorem, which highlights the significance of property boundaries, to explore several boundary scenarios in planned zoning that are of policy significance. They are conflicts of
\end{abstract}

\footnotetext{
${ }^{1}$ This paper is in memory of the late Professor Derek Robin Diamond.
} 
Progress in Planning

zoning, borderline non-zoning, incomplete zoning, forgotten zones, zoning for non-planning, rights-conferring zoning and codevelopment zoning. The transaction cost implications of these scenarios are spelled out. Examples from Europe, China, Australia and Americas are cited and elaborated where suitable to illustrate specific arguments.

Key words: Ronald Coase, zoning, boundary delineation, property rights, planning, surveying

Privatization involves the partitioning of this resource among separate users with a specific delineation of boundaries (Buchanan 1993: p.1, italics authors').

Boundary crossings must be expected to occur, even when property is clearly defined, because some persons will seek to obtain differential advantage by crossing borders... (Buchanan 1993: p.11, italics authors').

\section{Preamble}

Zoning as an ordinary expression and "non-zoning" as a technical term mean different things to different readers. In the United States, zoning is an institution that has great social and economic significance (Perin 1975). It is a system enabled by legislation and affirmed as constitutional by the Supreme Court in Euclid ${ }^{2}$ with respect to regulating land use and development beyond common law restrictions, and in modifying common law rights. "Non-zoning," which prevailed in Houston, Texas and as profiled by Siegen (1970), went against this norm as a radically unique, but feasible, "private city" and "private planning" alternative: a looming paradigm with a

\footnotetext{
${ }^{2}$ Village of Euclid v. Ambler Realty Company 1926. See for instance Epstein (1996).
} 
Progress in Planning

Coasian transaction cost connection (Glasze et al 2004; Andersson and Moroni 2014) in current planning inquiry.

On the other hand, "Non-zoning" in England does not refer to "private planning," but is professional planning law terminology describing local government development controls, which require permission for almost any "change in use" or development. Upon closer analysis, this English "non-zoning" system does not differ much from what is formally understood as a zoning system elsewhere. For example, it is little different from the system in New South Wales, Australia, except that there the Local Environmental Plans provide for columns of always permitted and permissible uses, as in a typical U.S. zoning regime.

This monograph seeks to focus attention on the point that the spatial delineation of land is fundamental to any spatial division of labour in social and economic activities. This is real zoning in its broadest generic sense, underlying both private property and state planning whether expressly called zoning or otherwise. In this light, "non-zoning" in Houston can be better described as "private zoning" rather than "private planning" by restrictive covenants. For the latter makes sense only because it is based on a hidden framework of state zoning in the pattern of subdivision of the original private property lots, and by other regulations that serve planning purposes. Also, "non-zoning" in England is, in fact, a bona fide zoning regime, as the whole local government area, which clearly delineates jurisdictional boundaries, can be regarded as a zone within which the provisions of the town planning legislation of the time applies.

\section{Part 1: Introduction}


Progress in Planning

From a historical perspective, the delineation of land with planimetrically accurate boundaries for private land ownership, whether through a haphazard or gradual process for properties possessed from "time immemorial" or according to a state subdivision plan for a newly-annexed territory, is an essential prelude to the unitization and commodification of properties by lowering the transaction costs of valuating the property. In the latter case, planning or zoning by contract can occur $a b$ initio, as in the case of many British colonies, where the land was granted subject to state planning controls. Treated as 'natural' zones for planning by proprietors, these privately-owned land lots were "rezoned" when subsequent modern zoning was imposed on them by the state for whatever reason.

This wide understanding of zoning helps evaluate the transaction cost implications of several real world scenarios of zoning in relation to such recent specific planning phenomena in China as "villages in cities" and wider practical concepts such as "takings," "land adjustment," and the "transfer of development rights", etc. Transaction costs, in the Coasian tradition, refer to costs that cannot be captured by a neo-classical production function. In this monograph, the focus is on the notion of "clearly defined property rights" in the Coase Theorem applied to land in the sense of clearly delineated property boundaries (Lai 2007). The Coase theorem, to be elaborated in Part 3, was derived from Coase's 1960 work (Coase 1960) and its farming story of two adjoining pieces of land with clearly delineated boundaries ${ }^{3}$. With respect to resource allocation of land to cattle ranching relative to wheat farming as between these domains, as demarcated by the location of the mutually agreed adjustable de

\footnotetext{
3 This "clearly defined legal boundaries" exhausts the meaning of "clearly defined property rights" under the Coase Theorem. For the reason behind this, see Lai (2007: p 350).
} 
Progress in Planning

facto common boundary, depends purely on relative prices of farm produce and is invariant to the de jure border. In this hypothetical world, institutional designs including laws and policies are redundant and in any case would not affect resource allocation. This theorem assumes that transaction costs are zero. The practical application of the theorem lies where such costs are exactly positive, a scenario covered by the "corollary of the Coase Theorem," when institutional designs - and precision or otherwise of boundary delineation - are significant in resource allocation.

Zoning is meaningless in the absence of a spatial division of labour in production and consumption: a nexus of physical exchange manifested in transportation and innovatory and other social exchange. These in turn imply mutual dependence and cooperation as well as competition and rivalry. Zoning is therefore to be understood as a matter of expediency that facilities such exchange. This accordingly calls attention not only to private property owners, but also to "stakeholders," who do not hold land under the law, yet who are nonetheless significant in social transactions. Ignoring this results in a narrow view of private property that stresses exclusivity, whether as economic "defendability" (Fleischman et al 2014; Acheson 2015) or "might makes right" (Umbeck 1981), and forsakes the social function of private rights; rights contingent on and thus also serving the common good.

A difficult question raised in this monograph, for those who equate legislative or statutory zoning to town planning, is how pre-legislated urban or rural development was actually ordered in the United States between Lord Shaftesbury's Board of Plantations' Grand Modell, as followed in the laying out of Philadelphia, and Euclid. Equally, how were things ordered in Hong Kong between 1842, when the first sale 
Progress in Planning

of leasehold interests was held, and 1939 when a Town Planning Ordinance was enacted, with its preamble modelled on Euclid. As instruments of planning for these two far apart cities, the town layouts were products of the visible hand. This puts into proper perspective the insightful work of Li (2014) which argues that the techniques of surveying and zoning are modern means ("inscription devices and modes of calculation") to picture land's "resourcefulness" to make it "investible" in the common mind. ${ }^{4}$

To shed light on this question, the rest of this monograph is organized into 5 parts. Part 2, "the prevalence of zoning", explains that boundary delineation is a characteristic of land as private (or more generally exclusive) property. The tension between penumbrality and exactitude of zone boundaries, which can be denominated in terms of transaction costs, is explained. Part 3 offers a Coasian stance on zoning as boundary delineation treated as an essential institutional arrangement for land property. Part 4 is a literature review, which shows with reference to textual materials that boundary delineation is fundamental in academic and professional understanding of zoning; that two fundamental and erroneous assumptions about zoning are that it is seen only as a state planning method and is always imposed unilaterally by the state; and that zone boundaries are treated as decision variables without reference to lot boundaries. Part 5 examines 7 scenarios of zoning, namely conflicts of zoning; borderline non-zoning; incomplete zoning; officially forgotten zones; zoning for non-planning and codevelopment zones. Part 6 concludes the monograph and Part 7 is the bibliography.

\footnotetext{
${ }^{4}$ The drive to planimetrically correct cadastral maps in USA began as early as the 17 Century. See Stilgoe (1976).
} 
Progress in Planning

\section{Part 2: The prevalence of zoning}

As new lands were acquired, a first priority was to survey them. The mapped cadastral survey was one of the most powerful instruments available in the colonies for allocating the prime resource - land. ... He [the land surveyor] was the instrument for imposing a whole new economic and spatial order on the territory.... In the process he usually extinguished pre-colonial land rights.....The land surveyor was an explorer, resource appraiser, town planner, delineator of routeways, and the shaper of landscapes both urban and rural." (Home 1997: p.37)

The spatial partition of land, whether by governments or private bodies, whether as a result of deliberate planning or other more spontaneous arrangements based on ingrained assumptions, intuition or experience, is a basic land use planning activity that entails decisions on boundary delineation, on their clarity and on their maintenance. As private property, the resultant parcels or "places" as often technically referred to as "lots", which is the term we shall use primarily hereafter - are natural and truly (though seldom so called) "zones" or units of planning 5 for both their owners and the state. Such units have definite, though as we shall note not necessarily conceptually precise boundaries often initially traditional, although with time - and in the case of the colonization of "new continents" - fixed by the state and protected by the law adjudicated by the courts.

At this point it is necessary to pursue a Lockean exercise in 'clearing the ground a little' (Locke (1959), vol.1, 14) to clarify the terms of this discussion. What we may style the 'unit' with which discussion of the economics of property rights and planning is normally concerned is the, 'place', 'plot' or more technically (in the parlance of practitioners in law, real estate, surveying and planning) 'parcel' or 'lot'.

\footnotetext{
5 These are proprietary units and are not the same as "planning units" in UK planning enforcement law. In Rawlings v. Secretary of State for the Environment and Tandridge DC (1980): The determination of a "planning unit" was a matter of fact and degree for the decision-taker and the occupation and ownership were not conclusive.
} 
Progress in Planning

Conceptually this is a geographically delimited, legally defined territorial whole exclusively owned by a single juridical entity, the owner or title holder. The delimitation is both legally and geographically defined by a 'boundary': conceptually a continuous Euclidean 'line' joining Euclidean 'points', each of which is 'located' in a geodetically defined geographical space by precise survey methods though, as we shall see, in practice often something very much less abstract: a matter of significance in planning. ${ }^{6}$

Whether traditionally respected or formally legally established, property boundaries of privately occupied lots can therefore be physically represented as lines on maps and by structures ("metes and bounds") on the ground. These boundaries are generally honoured de facto, even if the property in question does not have de jure status as, for example, with entirely traditional land-holding systems. Respect for these de facto boundaries would, in time, gain them quasi de jure status if transactions are well-witnessed and recorded by a credible organisation.

It is probable, though no final determination is possible without the historical inquiry that is sadly generally lacking, that this core conceptual unit of a 'lot' is empirically a derivative, rather than a fundamental unit. The evidence is not decisive, but anthropological research and subsequent descriptions would suggest that, whilst the concept of individual 'ownership' - perhaps better 'accepted more or less exclusive use' - of objects may be in some sense and probably in the majority of early societies prior ("this spear is mine", Veblen 189899), in the case of land, group or communal ownership emerges from rather different sources (Demsetz 1967: pp. 350-353, Renger 1995: pp. 271-272, Acheson 2015). That is, the core 'land' unit the group

\footnotetext{
${ }^{6}$ A Euclidean 'point' is defined as 'that which has no part' (i.e. dimensionless location) and a 'line' as 'breadthless length/extension', Fitzpatrick, R. (ed) (2009), 6, Definitions 1 \& 2.
} 
Progress in Planning

'owns' - or 'uses by acceptance' - is in some sense (to be elaborated below) less conceptually unitary because in practice less geographically precisely specified. In other words, communal property rights preceded private property rights, which latter fit better an economy of greater spatial division of labour. It is a 'territory', or perhaps less tendentiously an 'area' with or to which a group or community feels it has what we may identify, in anachronistically modern terms, as rights of belonging and rights of use, but which in those early times often did not have a sharply defined boundary either in space or through time. At this junction, it should be noted that though common property with a spatial dimension as recognised de jure (as a "regime") necessarily has boundaries (set by communal or private property for itself), no partitioning into zones is socially accepted.

In the passage of time emerged what has become, though never exclusively or universally, the modern private property regime that stresses exclusivity. The pivot of change has conventionally been pinned to the emergence of the Neolithic Revolution (Bellwood 2004, though for a counter-view see Hole 1984). This 'moment' has generally been taken to represent a historically relatively brief period of at most a few millennia during which human society underwent radical economic, social and political transformation at the end of which a nebulous idea of "our territory" had become conceptually "sub-divided" or "partitioned" in the sense of Buchanan (1993) and changed into conceptualizations of land holding and ownership that are recognizably ancestral to today's.

We introduce this matter to distinguish in terms of property between the concept of a 'lot' and, via the idea of a 'territory,' that of a 'zone'. We may say, perhaps somewhat stipulatively, that in 
Progress in Planning

common usage 'lots' may be found in or grouped into 'zones' that are themselves significant subdivisions of 'territory'. Within the 'territory' 'zones' may have included in them or be used to define or otherwise order 'lots'. But whatever may there be the case, the logical grammar we have speculatively outlined does suggest a point of interest to the discussion that follows. This is that the concept of a 'territory' or 'area' would appear to include, if somewhat loosely, internal spatial differentiations in terms of function that, if we are correct in the ontogeny of the idea of the private ownership of land, has subsequently carried over via 'zones' into the narrower sphere of private 'lots'.

Following this line of thought, we may postulate a world in which we understand 'our territory/area' as one divided into 'spaces', or 'zones' appropriate to certain sub-groups, functions, etc., as a matter of spatial division of labour, later to be further enabled by and promoting development of communications links and, derivatively, transportation. For example there may be areas where visitors stay, another where animals are corralled, other areas where animals are butchered, others where food is stored, yet others where it is processed.

Implicit here, and another point to which we shall revert, are the necessary pathways for intercommunication that such zones entail. That is, if 'butchery' happens here, 'storage' here and 'cooking' here, pathways will spring up that enable us to move the products of butchery to store and from store to kitchen. These pathways, precisely because we are differentiating space by function, are not themselves included in any specific functional space. Rather, they are outside the various spaces (or zones) and, by derivation, either do or may come to form the divisions that separate zone from zone: in short, 
Progress in Planning

they are boundaries. Note, however, that on that analysis a boundary formed by a route is markedly different from the sort of Euclidean boundary that demarcates a zone.

At a different conceptual level, 'our' space may also be divided into 'zones' for males and others for females; for the dead and for the living; for the sacred and for the profane and so on. With a subsequent development of concepts of private property carved out of 'our territory/area' as identifiable 'lots', we can now see how they may in some sense be subordinate to possibly existing 'zones' in which some activities or category of person may be de jure or de facto allowed and others not.

Equally, however, that manner of sub-dividing space through which a society's practices come to define and conceptualize spaces by 'zoning' would seem also to have been carried into the sphere of private property - the world of the 'lot'. Thus within a given private space, a 'lot', 'zoning' also occurs. In time a private space perhaps initially crudely divided or not divided at all, comes to reflect the more complex conceptualization of space familiar in the public domain. Perhaps initially no more complex than 'outside' and 'inside', later comes greater and greater refinement. Where we wash. Where we defecate. Where we bury/burn the dead. Where the animals live. Where we sleep. Where we eat and so on. James Metzenbaum (1956), who was counsel for the Euclid Village, traced the origin of modern zoning to "fire zones" imposed by ordinance to restrict storage of gunpowder to outside a town. In a lay person's language, he characterised zoning as such:

"Housekeeping for municipalities is, under zoning, finding an orderliness. Zoning is merely keeping the kitchen stove out of the parlor, the bookcase out of the pantry and the dinner 
Progress in Planning

table out of the bedroom. It provides that houses shall be built among houses, apartments in apartment zones, stores in store zones, and industry in zones set aside for industry." ${ }^{7}$ (Metzenbaum 1956: p.41)

A final important point that needs to be elucidated, emerging from the brief discussion above on pathways, rests on what we perceive to be the complex logical grammar of the concept of "zone". We have noted how in the context of modern planning and planning theory "zone" is logically dependent on the concept of a boundary and, specifically, on the strongly Euclidean understanding of a boundary that has emerged from the cadastral surveying on which the whole edifice of private property legally rests. However, what is not often either noticed or commented on is a quite separate sense of "zone" a usage perhaps most elegantly expressed in the title of the popular 1950s American TV series "The Twilight Zone" that enjoyed two revivals in the 1980s and 2000s.

This separate sense we identify in terms of 'penumbrally bounded'. That is, a zone that is not reducible to Euclidean coordinates and the lines that join them, but one that ineluctably carries with it a sense of imprecision and incompleteness: a sense that its limits are not only loosely defined and definable, but therefore in principle both elastic and moveable. A zone is somewhere that, at its limits, is by definition disputable, though that does not assert that it is therefore necessarily disputed.

\footnotetext{
${ }^{7}$ Eloquent and reasonable as this sounds, problems immediately arise when one wonders if a bank office or a sandwich bar should be allowed in housing and industrial zones or if flats must be zoned separately from houses. The author was calling for a very conservative use of zoning. He concluded, "It is the duty of the lawyer to fight for the preservation of such rights and not to permit overly zealous zoning experts who draft ordinances nor obliging Councils who pass them, to promulgate legislation which is unreasonable or which unlawfully tends toward the divestment of the property owners' constitutional rights." (p.42) He did not expect that planning lawyers would "seek rent" from a highly complicated zoning legislation.
} 
The concept of "zone" in modern planning policy is in principle and overwhelmingly that of a precisely delineated area within which use, style, function or social stratum of the inhabitants may be exactly prescribed. However, if this analysis is correct, then any planning zone must also always, though less visibly or even invisibly, inhere this sense of inexactness and hence disputability. Given that we are necessarily always dealing with public policy, then evidently this larger if looser concept of "zone" has significant policy and planning implications. Any use of the term "zone" and its variants also carries with it the more penumbral meaning. Despite this, as far as property and planning law go, all lot and zone boundaries drawn at any map scale are deemed to be certain and exact, with the court as the final arbiter in case of disputes among property owners/claimants or between the state and these owners. (Lai et al 2015)

This tension in practice between a core 'penumbrality' and a legal exactness works both spatially and through time, as we shall see both in the lacunae in discussions of zoning in the literature reviewed in Part 4 below and when discussing some of the scenarios in Part 5 . In short, any zoning, whilst aiming for what we might style precise, deliberated outcomes ("This here, precise boundary, that there."), also necessarily thereby creates an imprecise, disputable penumbra ("This here, imprecise penumbra, that there.") that has significant policy effects.

\section{Figure 1A and Figure 1B about here}

Caption for Figure 1A: Natural, Terrain Following Boundaries with Spatially Inexact Markers and with Eastern Boundary Indeterminate 
Progress in Planning

Caption for Figure 1B: The Same Bounded Territory with Superimposed, Surveyed Boundaries Rationalizing the Customary Boundaries and Removing the Indeterminacy of the Previous "Fuzzy" Eastern Boundary

Figure 1A and Figure 1B shows this world of tension and penumbrality with a customary boundary that, once surveyed and brought into the world of private property, encircles two 'lots' themselves divided by a typically rectilinear modern surveyed boundary. The intention is to show the original fractal 'wiggliness' of the customary boundary as it follows the rumpled actuality of the landscape and how boundary markers, whether natural like trees, boulders and streams, or artificial like drainage channels, road/track or hedge corners, are superimposed on this potentially implicitly Euclidean line. Figure 1A also shows, in its indeterminate eastern boundary, how customary conceptions of space can inhere indeterminacy; an uncertainty as where 'our space' stops and 'their space' begins. We shall revisit this thought in Part 5: Scenarios of Zoning. Equally therefore, the two diagrams serve to show the lesser, but non-negligible implicit penumbrality of the modern, surveyed boundary between the two lots precisely because it is that: a boundary.

Where the outer, customary boundary is concerned, the diagram also shows how, from the perspective of surveying and mapping such a customary boundary, a cost-efficient chaining (or these days laser sighting) 'straightens' minor irregularities, such that the concatenation of surveyed straight line bounds overlies the fractal and chaotically curvilinear actuality. This also indicates a usefulness to the scalar mismatch inevitable in any mapping that is not to a scale of 1:1, in that the 'width' of a mapped boundary serves at least in many cases to embrace wiggly actuality by recognizing that the surface of the Earth is non-Euclidean. 
Progress in Planning

By contrast the surveyed 'modern' boundary is depicted as suffering from only one aspect of penumbrality, namely the fuzziness resulting from scalar mismatch, where the resulting mapped boundary is not a Euclidean widthless and hence indisputable line, but a disputable 'zone' that, depending on the scale of the survey, more or less fuzzily distinguishes lot A from lot B.

\section{Figures $2 \mathrm{~A}$ and $2 \mathrm{~B}$ about here}

\section{Caption for Figure 2A: The Coase Theorem}

Caption for Figure 2B: The Corollary of the Coase Theorem

Taking those general points and applying Coase's idea about property boundaries, Figure $\mathbf{2 A}$ and Figure $\mathbf{2 B}$ demonstrate the question of zone boundary in terms respectively of the Coase Theorem (without any penumbra) and the corollary of the Coase Theorem (with penumbra) with vague boundaries due to competing interpretations of boundary stones/landmarks. Figure 2A shows a scenario without transaction costs in de jure boundary delineation for land Lots $A$ and $B$ granted by the state. Figure 2B shows certain domains of $A$ and $B$ with 7 penumbrae over which de jure property rights can be uncertain and contested by the state. We may observe here an historical trajectory, generated by improvements in the technology of survey accuracy, to move from a block boundary marker (a stone, a tree...) with its inevitable penumbral indeterminacies as depicted in Figure 2B to the modern, zero-point marked cadaster that has the specific product of narrowing the penumbra towards, though never achieving, Euclidean evanescence, as conceptualized in Figure 2A.

Another way of putting that, referring back to the brief discussion of zone divisions formed by pathways above, is to ponder the 


\section{Progress in Planning}

uncertainty of any such pathway. Is it a pathway within a zone? Or is it a pathway between zones? We can mentally map this uncertainty by imagining a large space subdivided into zones and within zones into lots. Paths join lots within zones. And paths link zones. In both cases what matters about the path is that it gives access from any lot/zone $\mathrm{P}$ to any other lot/zone $\mathrm{Q}$ without, as it goes from any $\mathrm{P}$ to any $Q$, encroaching on $P, Q$ or any other lot/zone. Evidently such a pathway is not itself strictly 'in' $P$ or $Q$ but always, in some sense, spatially and hence zonally neutral (Jarzombek 2010). It is often classified as a zone on its own as on large-scale plans.

This may partly explain why there is an observable tendency for zonal planning to be done on small scale maps. By definition any line on a small scale map covers a swathe of territory, not a precise bound, thus creating an undefined spatial void (in effect hidden borderline areas or zones) running along the border lines, which are intended to segregate uses on either sides of them: "Somewhere between here and there we stop permitting this and start permitting that", or more generally, allowing for non-planned planning, "This gradually turns into that over this intervening tract of territory." With the implicit rider, "Once we've firmed up the plan we'll start turning gradual into exact." That this is not an outlandish approach to zoning can be readily appreciated if we consider the unacceptable (but sadly common) ideas of zoning by ethnicity, caste, occupation or social class and the inevitable human tragedies that ensue, especially at the extreme in crimes against humanity like ethnic cleansing.

The costs arising from the tension between the penumbrality and exactitude of zone boundaries are not costs of production and therefore Coasian transaction costs. This provides a map scale explanation, as a matter of transaction costs, which adds to the usual 
Progress in Planning

information cost constraint problem (the state's information ignorance about the operation of private enterprises as land users) advanced against top-down interventionist government state planning. Namely the conflict between government plans and private property rights. The fact is that the government planner seldom proceeds, as the development market works, bottom up from individual property lots where the result is the production of a plan that has its foundation ("base map") resting on a composite of large scale ${ }^{8}$ plans each designed for an individual lot.

The digital revolution has reduced the transaction costs that once prohibited a bottom up planning approach respectful of property boundaries. It also avoids the scenarios of "conflict of zoning" and "borderline non-zoning" to be mentioned later. Transaction costs, in neo-institutional economics, refer to costs that cannot be captured by the neo-classical production function. In other words, they cover costs of information, time, contracting and political bargaining, and dishonesty, etc. Douglass North estimated that more than $70 \%$ of the GNP of the USA is made up of such costs. Neo-institutional economists, following the teaching of the late Ronald Coase (19102013), 1991 Nobel laureate in economic science, consider that institutional arrangements affect these costs. As elaborated in Part 3, zoning is just such an important institutional arrangement.

We would argue that a thoughtful look at pre-rationally planned urban and rural areas would more often than not show exactly the sort of "this use, mixed use that use" pattern we should expect supposedly "unplanned" societies and economies to exhibit. In short, the very concept of a "zone" is one that marches uncomfortably with

${ }^{8}$ Say $1: 600$ to $1: 1000$. 
Progress in Planning

the concept of a "lot" or "parcel". Lots or parcels are precisely delineated. They are ownable and tradable, however that trade may be effected. On this analysis, because of their penumbrality ${ }^{9}$, "zones" are in an important sense beyond the market, despite their significant effects on private property rights, especially the more ineluctable effects occasioned by penumbrality on market activity. As we shall see in the scenario we have labeled "forgotten zones", it is precisely this quality of a "zone" that is too often and too easily neglected.

It follows from this highly general and conceptual discussion that the tightly defined 'physical space', in which the creation of property and the activity of planning locate, must always also be read in terms of other conceptualizations of space (Thrift 2003). These, like Thrift's 'unblocking, 'image' and 'place' spaces are less easily confined by the exigencies of cadastral controls.

\section{Part 3. A Coasian stance on zoning as a matter of boundary delineation}

One of the neglected contributions to the spatial dimension of planning by Coase is the idea that subsequent adjustments in the boundaries of these spatial units by the state or a private entity are best conducted by mutual consent. The rationale is that this incurs much lower transaction costs in dispute resolution and less political resistance than achieving the same end by order. For example interventionist state planning, which often ignores, denies, or overrides private property ("lot") boundaries without compensation, is frequently not only resented but actively resisted. We may say that

\footnotetext{
${ }^{9}$ The argument here does not contradict the position of Walker and Peters (2001) that many so-
} called "blurred boundaries" are in fact disputes over "clear and distinct" meanings of boundaries. 
Progress in Planning

dispute resolution between private lot holders is penubrality/uncertainty sensitive in a way that more formal regulatory systems are not, given that the penumbrality/uncertainty is generated by micro-level information, time, bargaining, honesty, etc.: costs of which the rights holders are aware in a way that the more 'one size fits all' approach of state regulation is not.

Coase's idea is encapsulated in a farming parable involving a conflict between two land uses by two adjoining farms. This was resolved by private agreement to adjust the ratio of land devoted to the two uses by altering the de facto boundary and so areas for the two uses. That is, there was an adjustment to the common land boundary by the mutual consent of both parties to the conflict. The late George Stigler (1911-1991), Coase's colleague and fellow Nobel laureate (1982), generalised this hypothetical example of resolving conflicts of interests between two producers to reach win-win solutions that maximises joint value output through the private exchange of rights under different market conditions for the products into the so-called Coase Theorem. The exchange of rights solution is often described as a free market or contractual solution (i.e., one devoid of express spatial referents).

Stigler formulated two versions of the Theorem. The first is called the invariant theorem. It may be stated as: "given zero transaction costs and clearly delineated property rights, institutional arrangements do not affect resource allocation." The other is the optimality theorem: "given zero transaction costs and clearly delineated property rights, resource allocation is Paretian efficient." The land boundary dimension of the parable or of the theorem itself has been missed by many friends and foes of the Coase Theorem, including Stigler, because they focused on the validity of the assumptions of "zero transaction costs" and "clearly defined property rights," with the latter treated a-spatially, forgetting that the parable 
Progress in Planning

involves a necessary initial delineation of the farms' de jure boundaries and subsequent adjustment in the de facto boundaries of land devoted to the two specialized land uses.

Probably due to Coase's background as an economist and this important work's appearance in the Journal of Law and Economics, the Coase Theorem has become best known in the economic and legal fields. However, by virtue of the fact that the conflict of interest in Coase's imaginary story was actually a land use conflict - one between wheat cultivation and cattle grazing - the Coase Theorem is, more rightfully speaking, a land use planning theorem with a modern land surveying and Grand Modell (see below) lot delineation (visible hand) foundation. The heart of Coase's parable is the partitioning (zoning) of ranching and wheat planting and the key fact is that the conflict resolution involved an essential spatial element that contrasted with government planning, More precisely, the Coase theorem is a land use zoning theorem because the spatial delineation of land is an essential element of land use planning, as we have considered that issue in our introductory discussion above. This would appear always at some level to have been the case as this monograph will now further explain.

At this juncture, it must be pointed out that economic theorization of urban development ${ }^{10}$ has ignored the spatial boundary dimension of land, treating it as a factor input (especially fertility), a quantum of area or points along a time line or ruler. This a-spatial treatment of land becomes more problematic, when land is dealt with as a matter of property rights, when land boundary delineation is treated as a given parameter rather than a decision variable. In the story of Coase as encapsulated in the aforesaid Invariant Theorem, the initial and subsequent locations of boundaries

\footnotetext{
10 The importance of boundaries is better recognized in environmental economics research. See for instance Fleischman et al (2014); Acheson (2015); and Yin et al (2013).
} 
Progress in Planning

are decision variables. Good exceptions are the work of Allen (1991) on American homesteading based on grids; the comparative study by Libecap and Leuck (2011a) on metes and bounds vis-a-vis grids in Ohio; and the study by Libecap et al (2011b) on the choice of private lot boundary types in several common law jurisdictions. The papers of Libecap and his collaborators, written from a choice-theoretical perspective typical of neo-institutional economics, were informed by the detailed historical and map analysis of Price (1995), which is indispensable for any planning student serious about modern zoning by legislation or contract.

Price (1995) presented various patterns of land as that was first sub-divided into lots for the first settlers in the thirteen British and the French colonies in America. The origin of these patterns, which vary between ribbon shaped "longlots" (also known as "ribbon lots" or "elongated lots"); grid type parcels; polygonal lots that averaged 8 sides; and irregular metes and bounds allocations can be traced to earlier European home-country experiences. Given that, it would not be an exaggeration to argue (from a choice theoretic stance of the neo-institutional economist) that the adoption or "choice" of each of these patterns was the first significant planning act of the colonial administration. And it was so by virtue of the fact that from the outset the land over which generations of indigenous tribes had roamed and had defended as communal property was treated as common property.

Subsequent development, in the jargon of economists, has been "path-dependent." The landmark work of Home (1997), which does not cross reference Price (1995), traces the origin of British town and country "master" planning for colonies to the Board of Plantations, which became the Colonial Office, and more specifically to the so-called "Grand Modell" of Lord Shaftsbury, and a series of 
Progress in Planning

legal enactments for colonies notably the 'Act of Building a Towne' of 1662.

The Modell had its origins in "the bastide towns of medieval Europe, (in) Renaissance and Baroque revival of ancient Roman planning, to the Spanish Laws of the Indies and even to a seventeenth century plan of Peking." (Home 1997:p. 8) Home concluded that this model, as applied with modifications, is one with a number of characteristics. Deliberate urbanization to avoid dispersed settlement. Differentiation among town, suburban and country (farm) lots. "The town planned and laid out in advance of settlement." Wide streets laid out in geometric, usually grid-iron form, usually an area of "one square mile." "Standard-size rectangular plots." Public squares. Lots reserved for public purposes. And "buffering town and country by a greenbelt or common land." (Home 1997: p.9, Underlining authors') The Modell, was applied in modified manner to suit local conditions.

In layman's terms, as Price summarized the matter, "Whatever their form, landownership (cadastral) patterns are among the most persistent features of the human landscape." (Price 1995: p.6) The rigidities of these patterns in shaping landscape, easily discerned in any aerial photograph and demonstrated in Figure 3, which shows the correspondence between modern roads and the boundaries of Lot 2 in the Lot Plan for Perth (Welshpool area) laid down by Surveyor General John Septimus Roe, puts into proper context London architect Cedric Price's witty three-egg-recipe account of urban transition. It moves from boiled eggs with solid and smooth outlines with a definitive yolk, via a fried egg the outer edge of which breaks up into fractal chaos but still with a distinctly bounded yolk, to scrambled eggs without any clear prime centroid or tidy fringes. Town planners in both public service and private practice certainly are 
Progress in Planning

accustomed to impose an order, invariably hierarchical, onto the urban mosaic presented to them as the "base (map) scenario".

\section{Figure 3 about here}

Caption for Figure 3: The Road Map of Lot 2 of Perth

Of course the 'shape' of even the most coherent fortified Roman or medieval city was never the neat 'boiled egg' it was mapped as being. Lean-tos and 'illegal structures' within the urban area that invaded the yolk's space did not appear. Shacks abutting the outer walls were ignored. Shanties straggling out along approach roads were at least conceptually cleared. It was a happy joke in an atlas design office in which one of the authors once worked that atlas designers had the power to make rivers straighter or wigglier, roads more direct, coastlines less chaotic, borders more exact and straighter. That is the inevitable consequence of the scalar mismatch between a conventional sign (built up area, road, railway, river, boundary) and the map of which it is a part. Were the road or pier to be to-scale, save on maps of the largest scale (1:600 in the past before metrication and 1:1000 now for example), they would be invisible.

For the leased New Territories in Hong Kong, from 1899 to 1903 the colonial government carried out a cadastral survey of settled land divided into 477 Demarcation Districts (DD) of about 200 acres each, with the help of surveyors seconded from British India. For each DD, one to-scale "Demarcation District Sheet" ("DD sheet"), combining cadastral and topographical details drawn to a scale of 1:1980 with numbered lot holdings, was prepared and a Block Crown Lease (BCL) issued in 1905. The inked boundary line itself, when scaled to on-theground size, measured about 1 metre in width. In 2015, the average property price for a residential unit in Hong Kong was more than HKS100,000 per square foot. It follows that a metre of boundary, 
Progress in Planning

approximately ten square feet, was HK\$1 million's worth of disputable terrain!

Purely theoretically, therefore, it is obvious that a boundary, that Euclidean object, should never be visible at any scale. It is the perfect and complete line of division between two exclusive spheres of private ownership over which disputation is in principle impossible. Sadly, as a moment's thought suggests, such absolute precision must stumble into Mandelbrot's fractal world and the assiduous mapmaker and planner, resolved on cadastral clarity, could only settle, with Borgesian resolve, for a scale of 1:1 (Mandelbrot 1982, Borges 1975).

“... In that Empire, the Art of Cartography attained such Perfection that the map of a single Province occupied the entirety of a City, and the map of the Empire, the entirety of a Province. In time, those Unconscionable Maps no longer satisfied, and the Cartographers Guilds struck a Map of the Empire whose size was that of the Empire, and which coincided point for point with it."11

To set the scene Figure 4A is basically the same as Figure 2A but the privately negotiable area between the owner of Lots $A$ and $B$ is depicted. This area is neatly delineated by the de jure perimeter of the two pieces of land. There is no need for any court or bureaucratic assistance or direction in delimiting the de jure boundary to facilitate an exchange of rights (how much land is leased to/from the other party). Figure 4B is identical to Figure 2B showing areas over which owners of Lots $A$ and $B$ can negotiate with certitude in the absence of any court or bureaucratic (state) assistance or direction in delimiting the de facto boundary upon exchange of rights. Figure $4 \mathrm{C}$ is what follows from that shown in Figure 4B upon court or state determination of the common de jure boundary. The joint area of Lots

11 In Borgesian fashion this is offered as a quotation from the seemingly actual but in fact entirely fictional Suarez Miranda, Viejas de varones prudentes, Libro IV, Cap. XLV, Lerida, 1658. 
Progress in Planning

$A$ and $B$ that can be privately negotiated is smaller than that in Figure 4A due to six penumbrae.

\section{Figures $4 \mathrm{~A}, 4 \mathrm{~B}$ and $4 \mathrm{C}$ about here}

Caption for Figure 4A: The Coase Theorem in Action

Caption for Figure 4B: The Corollary of the Coase Theorem in Action (without determination of common boundary)

Caption for Figure 4C: The Corollary of the Coase Theorem in Action (with state/court determination of common boundary)

The interesting question is therefore one about the role of maps in the planning process and the extent to which planners are conscious of any map's inherent and indelible limitations as a depiction of reality. Is the planner in charge of the map or the map in charge of the planner?

There is a cognate slippage between walking and measuring the bounds of a property. On the one hand is the property owner's inescapable awareness of the unevenness of the land surface, the kinks and jumps made around boulders, over ditches, etc. On the other is the surveyor's apprehension of the importance of distilling that natural fractal ${ }^{12}$ eccentricity into the scaled clarity of a twodimensional rendering for the purposes of legal title and planning. For the property owner and the local cadastral surveyor, perhaps there is always a healthy sense of the mismatches between map and reality. The gap expresses the transaction costs of information. But at more and more removes - land registrar, district planner, regional planner, national planner - the two dimensional depiction more and more

\footnotetext{
12 The key point about fractals is that they are dimensionally inexact - typically fractal dimensions would number something like 1.3785439, never exactly two or exactly three. This has obvious reference to the whole business of planning and its supposition of the exactness of dimensionality.
} 
Progress in Planning

becomes the reality to which, willy-nilly, the rumpled fractal surface of the Earth is obliged to conform.

Probably influenced by Chicago School rationalist-empiricism, geographer Price (1995: p.345), having discussed whether American experience was one of adaptation of European traits or a novelty, concluded that the "diversity of land division behaviour among the colonies enhanced the experimental nature of the land parceling in each colony." The economist certainly favours this "choice" approach. Assuming that approach applies, the question that then arises is whether we are considering 'informed choice', 'arbitrary choice', or 'prejudiced choice' (i.e. choice informed by unquestioned assumptions, patronage, etc.) or truly instrumentalist working assumptions?

The history of the opening up of the Swan River Settlement by the enterprising British naval officer James Stirling is illustrative of a conscious design story, no less impressive than the better known story of the planning of Adelaide by Colonel Light ${ }^{13}$. In the planning of this new colony claimed as British, Stirling chose to locate the capital town not in Fremantle, the port at the mouth of River Swan, but 10 miles upstream near Point Frazer, i.e. today's Perth City. (Statham-Drew 2004) This choice was based on the military security interest in locating the capital out of reach of bombardment by enemy war ships of the era. This concern was due to Stirling's naval experience in America during the War of 1812. Surveyor General John Septimus Roe, recruited by Stirling, devised a pattern of farm lots each with one end fronting onto a river for ease of transportation. As riparian access was scarce due to the number of grantees, these lots were all narrow "ribbon lots" or "elongated lots" (Stratham-Drew 2004: p.32), like those in French colonies which adopted the "arpent system" (Johnson 1974, Price 1995, Manning and Bekkering 2015).

${ }^{13}$ See Home (1997: pp. 26-29). 
Progress in Planning

Perth as a town itself was laid out by Roe according to a grid pattern, said by some commentators to follow prevailing Western style as with Williamsburg in the USA (Statham 1990) or Edinburgh new town (Proudfoot 1990). It is interesting that no commentator chose the early ${ }^{14}$ British colonial military cantonment (Edwards, 1992) as the possible model, since this is by far the most probable source. In any event, surveyors were prominent in the planning and/or mapping of land grants. Before Roe, a good example would be Surveyor General Thomas Holme, who mapped land allocations in Pennsylvania.

Indeed this congeries of colonial experiences is an area of planning history that has been too little explored. For implicit in it are two or possibly three imperatives entailed in what would have been a contemporary idea of planning: imperatives we would argue that in turn entail clear ideas of zoning. There would be two 'metazones'.

This would roughly differentiate the "occupied centre" metazone (the defended/defensible colonial township) from the "occupiable periphery" metazone (the colonizable land) - in modern planning terminology "buffer zone" - perhaps, depending on the nature of the specific colonization, accommodating some or all of any existing occupation/land use by indigenous inhabitants.

In the case of the growth in size of colonial Hong Kong, Hong Kong Island and Kowloon Peninsula, ceded by China in 1843 and 1860 respectively, constituted the "occupied centre" (with some tensions generated by inhabited villages at the time of occupation) while the New Territories, leased from China in 1898, was the "occupiable periphery" metazone. The differentiation, respecting topographical features, manifested itself militarily in the construction of the Anderson Line (Weir 2012) and Gin Drinker's Line (Lai et al 2009) across the Kowloon Range that forms the contact belt between the

${ }^{14}$ Home (1997: pp. 31) shows an example of the plan for Khartoum City but that was an early $20^{\text {th }}$ century product. 
Progress in Planning

two zones in anticipation of an enemy from the north: the enemy that arrived in December 1941. It is here, we might interject at this point, that one of our scenarios later to be discussed, the scenario of "forgotten zones" begins one of its most characteristic interventions in planning.

With the metazones established, focus shifts to zoning WITHIN the metazones. It is here that British colonial practice seems to have turned to some highly variable patterns, much hinging on how much the exercise was predicated on established British customary land use - one thinks here of the earliest settlement patterns in New England and the Virginia/Maryland areas (Price 1995) or, alternatively, on a more 'rational', post Age of Reason set of understandings of the sort one finds in such early to mid-19th century examples as Western Australia and, though in this case much affected by the exigencies of topography, Hong Kong.

Within the metazones, and most particularly within the occupied centre a different set of imperatives could be argued to have come into play. They can be theorized as having three "planning" dimensions that can be abbreviated as "segregation" of the rulers from the ruled; "control" by the rulers of the ruled and less obviously of the ruled by themselves; and "security" from the potential range of enemies both natural and social - i.e. disease and weather on the one hand and riot, mutiny or attack on the other.

Out of those considerations emerged the actual pattern of private property boundaries we can observe in any British colonial society, and from that initial set of actual boundaries would subsequently emerge, as discussed below, the patterns we can observe today and, perhaps, therefore the core inputs to modern, zone based planning of the ex-colonies. 
How private property boundaries have shaped and/or have been affected by subsequent modern zoning imposed on/across them is therefore a fertile area for Coasian empirical research. For example the old subdivision plans, especially for laying out agricultural lots, probably strike the modern planning student by their absence of delineation of any public road. There are two reasons for this. The first, where we are dealing with the layout of lots in newly colonized territory, is the absence of any long-established traditional tracks and paths that, in the established metropolitan societies, provided at least some 'natural' boundary lines. In short, the development of pathways noted above has not begun because there are none of the necessary relationships between lot holders. The second reason, directly related to the seemingly 'undeveloped' nature of the land as far as the movement of people and goods were concerned, was the dependence, in an era before the steam engine or internal combustion engine, on mainly maritime and riverine transport links.

The reach of the invisible hand of the market was shortened and the hand of the state suddenly stretched further and deeper in light of two pertinent questions that resulted from changes to these initial scenarios. First, how were railways and highways, as in themselves planned 'zones' for use by the general public, eventually to cut across side by side private lots if such routes were beyond what restrictive covenants among individual private lot owners could afford? Second, how were elongated lots (such as those along Swan River in Western Australia) to become widened to adapt to new modes of land use and transport? The answers likely involved voluntary surrender and regrant of private lots as well as exercise of the prerogative of the state to take land. Subdivision plans for town lots and modern suburban subdivision plans always provide for roads and community places, which, like the tracks and paths of yesteryear, often delimit the 
Progress in Planning

boundaries of private lots or serve as convenient mental boundaries for ethnic zones that naturally emerge. ${ }^{15}$

This monograph holds that the real world situation of positive (actually rampant) transaction costs actually renders the delineation of the boundaries of private property ('lots' contained in private zones) and those of any declared planning zones (public zones in government or public space, with its indelible penumbrality) extremely important in affecting the efficiency, if not also the equity, of land resource use. This assertion is demonstrated by several scenarios of what we shall collectively style 'zoning boundaries'. There are seven that we have identified. These are scenarios of conflicts of zoning; borderline non-zoning; incomplete zoning; forgotten zones; zoning for non-planning; rights-conferring zoning and co-development zoning within the context of the Common Law that prevails in the English-speaking world. We shall elaborate on the details of these seven scenarios in Part 5 below.

That set of demonstrations, supported by real world examples, does not offer a mere typology. Rather, by considering zoning as a spatial activity informed by neo-institutional economics, it suggests starting points for further research with policy significance. The zoning scenarios discussed below, as problems of boundary delineation by the state, pertain to the libertarian challenge to interventionist zoning, the primeval need for state involvement in private property matters, issues in universal human values, and conflict resolution.

To appreciate this proposition, there is a need to examine how zoning is understood and defined by scholars and practitioners who may or may not have any knowledge or interest in Coasian economics

\footnotetext{
${ }^{15}$ Hassan (2009) held that ethnic zoning in George Town, delineated by roads, was a policy rather than a spontaneous phenomenon.
} 
Progress in Planning

or the complex conceptual relationships entailed in our spatial language.

\section{Part 4: Impossibility of land use planning without zoning: a literature review}

The meaning of planning has been much debated, but the meaning of zoning has not. It is well accepted that zoning is a known and established means of land use planning. However, that urban planning always involves zoning needs some elaboration. Most studies on zoning do not define the term and simply proceed to discuss its social or economic implications. Consider, for instance, the works of Matjiya (2009) and Crowell (1931):

In its historical form, zoning was about exclusion. The protection of residential land uses from industrial and commercial uses, the imposition of density and bulk limits on buildings to prevent overcrowding, congestion, lack of light and air...It is clear that under the zoning concept the protection of single family residential use was of utmost importance (Matjiya 2009: p.24).

Zoning is the application of common sense and fairness to the public regulations governing the use of private real estate (Crowell 1931: p.326).

While these examples, given their specific objectives, did not need to dwell on the precise meaning of zoning, ${ }^{16}$ any endeavour to reinterpret planning as a concept for theoretical articulation should attract careful scrutiny.

To make the subsequent discussion clearer, and building on the general discussion in Parts 1, 2 and 3 above, we need here arbitrarily to distinguish two senses in which the term 'zone' and its grammatical variants appear to be used. On the one hand 'zone' is used to describe a non-formal, ad hoc achievement of some shared quality

${ }^{16}$ Unlike the work by Bassett (1924), which, despite its title, did not address the meaning of zoning at all. 
Progress in Planning

characterized by every built feature within a land area. That is, a 'zone' of farms, private residential houses, leatherworkers' shops, or whatever, that has emerged as a simple function of time and shared practices. On the other hand there is the sense of 'zone' as a goal of prescriptive or deliberate planning in which common attributes of buildings within a 'zone' are products of formal, declared and explicit requirements.

In both senses land use planning without zoning is inconceivable. Indeed, following our introductory remarks, we would argue that the first sense of zoning is logically prior. To the best of the authors' knowledge, there is no work suggesting that urban planning exists without zoning in this former sense. 'Zones' of private property (parcels or lots) with shared attributes, for example, were a common feature of places before ideas of formal urban planning were developed.

The mistaken belief that there may be urban planning without zoning is therefore likely due to the fact that there exists an officially "non-zoning" development control system in Britain and also perhaps to the famous paper on "Non-zoning in Houston" by Professor Bernard Siegan (1970). Upon our closer analysis of the meaning of zoning, neither English planning nor the Houston system is really unzoned. This is also revealed by the review of the literature on planning and zoning that follows. Some of the works specifically try to explain the nature of zoning or zoning provisions. Others only provide passing references to the concept. But zoning in one or other sense is everywhere apparent.

The human mind understands reality by abstractions and dichotomies are important forms of abstraction. Some dichotomies are real, but many are not. In land planning in the abstract two dichotomies that are commonly, if as we shall see mistakenly noted are of utmost significance, as they shape theorization and policy 
Progress in Planning

decisions, matters that are both practical and important. The dichotomies are between planning and the market and between zoning and non-zoning. It is highly tempting to assume these are two ways of making the same distinction by drawing parallels between planning and zoning on the one hand and non-zoning and the market on the other. Suffice it to say that the first dichotomy is not one because 'market' and 'plan' occupy logically distinct category spaces, which is not to say there are no difficulties in reconciling the market and any plan. The second however is a genuine dichotomy: the opposite of zoning is the absence of it (i.e., non-zoning). However, this may prove to be where logic (the world of abstract categories) parts company with actuality (the real material world), for following our two senses of the word 'zone' above, what we may think to be a case of non-zoning may actually be a zoning case in disguise.

One certainly cannot assert that a place is un-zoned simply because there is no official document called a zoning plan or map; the expression, "zoning," is not mentioned; ${ }^{17}$ or, more subtly, because there is no legislation that expressly describes "zoning". Even if legislation does not expressly call its control of land use and/or built form (as in the case of subdivisions and building codes) 'zoning', zoning is unquestionably the result. Similarly, without the word ever having appeared anywhere, agreement between property owners can result in a state of affairs that is indisputably 'zoning'. Above all, zoning of some sort is always inherent in any land tenure that is not de jure common and de facto open access ${ }^{18}$ by virtue of the

\footnotetext{
${ }^{17}$ A good illustration is the UK Town and Country Planning Act of 1947. As Burke and Taylor (1990) pointed out, "Although the term 'zoning' was not mentioned in the legislation...the principle (of zoning) gained acceptance and the allocation of uses and densities became the recognised means of control of land use in planning under the 1947 Act system" (Burke and Taylor 1990: p.43, brackets authors').

18 Many economists confuse common property with open access property. The former is a de jure status, the later de facto access control. (Lai and Ho 2014) Private property, notably that of the state, is often open access due to either the high transaction costs of enforcing exclusion or to deliberate social concerns. One may say that even de jure common property is 'zoned' in two
} 
Progress in Planning

delimitation of property rights along the spatial dimension. This last point is of paramount importance, as it has resource allocation, conservation, and transformation implications because it elevates the entire discussion beyond a taxonomic exercise in the understanding and evaluation of alternative modes of zoning in terms of property rights.

\section{Definitions of zoning in the literature}

What, precisely, is zoning? A good starting point for structuring a review is Professor Patrick Abercrombie's famous textbook, Town and Country Planning, which gave a succinct definition of it:

Zoning is the dedication of a certain area to a certain use (Abercrombie 1933: p.139).

Abercrombie's definition had two basic elements: (a) dedication of a specified area of land to a use and (b) the certain use to which it is to be dedicated. Element (a) entails the apportionment, delineation, demarcation, carving out, dedication, or encircling of land to create a "zone" or "district". A 'use' is generally functional (farming, light industry, residential) but often related to, if not identified as, a certain form of building (barns, factories, houses). In the UK, this was the advice of the Ministry of Town and Country Planning handbook, The Redevelopment of Central Areas.

This advocated, inter alia, that buildings with similar siting requirements should be grouped together while those with conflicting requirements should not be grouped together. The plan for development or redevelopment of a town should therefore provide for its division into a number of "use zones" each of which would be designed and equipped to provide sites suitable for the particular category of buildings" (Burke and Taylor 1990: p.43).

senses. First, in the obvious sense that the open access common property (say the public ocean) is itself 'zoned' by private property (coastal water zone boundaries). That is, this is a zone where anything and anyone goes without let or hindrance. Second, within an open access common property domain, zoning MAY occur precisely on the arguments advanced by non-zoning adherents to rebut any planning. Accordingly that zoning may be either temporal (it is autumn, the beech mast is on the ground, now is the time for pigs) or spatial/functional (sheep here, cows there (where sheep graze cattle can't, the grass is too short). 
Progress in Planning

Fischel's (1985) classic text, The Economics of Zoning Law, defined zoning more or less in the same way as Abercrombie:

Zoning is the division of a community into districts or zones in which certain activities are prohibited and others are permitted (Fischel 1985: p.21).

Professor Gordon Cherry (1996) had a similar definition:

The actual practice of town and country planning was securing a more technical base (during the period 1909 to 1930) as the principle of "zoning" was taken up, whereby "areas in which certain types of developments would be allowed were delineated as land use parcels in scheme layouts. (Cherry 1996: p.70; italics authors'.)

The same is true of Heikklia (2000), who described zoning maps as follows:

Zoning maps apportion the city into distinct zones, each of which has its own sets of permitted uses (Heikklia 2000: p.25).

In research papers and professional publications, there are basically three types of definitions, one of which does not expressly mention element (a) of Abercrombie's aforesaid definition, another that expressly mentions both (a) and (b), and a third that mentions neither (a) nor (b). The best example of the first group is the work by Lai (1997) and the review by Hirt (2012) on zoning. Although Lai's work treated zoning as a means to constrain rent dissipation and handle externalities, it defined zoning broadly and pinned it down as "boundary delineation" (Lai 1997: p.199). Hirt elaborated on it in the same vein:

...far from being universal, zoning (at least the type of land-use zoning routinely applied in the United States) is not practiced in Europe... (Hirt 2012: p.376).

A dictionary definition of the word "zone" is of little help. To zone is to merely carve an area, region, or district out of a larger whole. Zoning, therefore, is simply delimiting a territory or dividing it into smaller components (Hirt 2012: p.376, italics authors'). 
Progress in Planning

Carving out an area was the emphasis of Hirt's definition. Specifying land uses or activities was not essential. An earlier example in the same vein was provided by Skorburg (2008):

"What is zoning?" Zoning uses government power to create boundaries between land uses. It is illegal to zone via income, but not illegal to create minimum size lots - to lead to the same ultimate end. MLS (minimum lot size) encourages higher value houses and reduces the value of unimproved land where town stratification by income can result. Zoning increases land rents for the restricted sector and lowers rents for the poorer areas and can lead to area segregation (Skorburg 2008, italics authors').

Although Skorburg mentioned land uses, he gave no express requirement that such uses were prescribed or controlled, though he indicated the idea of restriction.

The second type of definition forms a much larger group and is typically generated by formal legal research, planning, public and professional bodies, and planning theorists. One example of legal research that offered a definition of zoning is the work of Borgan (1956-57):

"What is zoning? In general, zoning is the division of a designated area into districts for the purpose of regulating the present and future use, construction, and location of buildings and the use of land" per Rathkopf, I. (1956), The Law of Zoning and Planning 2 (Borgan 1956-57: p.507, italics authors').

Another example is Polsky (1975):

Zoning has been defined as:

(1) the division of a city by legislative regulation into districts and the prescription and application in each district of regulations having to do with structural and architectural designs of buildings and of regulations prescribing use to which buildings within designated districts may be put Miller v. Board of Public Works, 195 Cal. 477, 234 P. 381, 384 (1925) (p.995).

(2) The essence of zoning in a city is territorial division according to the character of the lands and structures and their peculiar suitability for particular uses, among other considerations, and uniformity of use within the division. Per Collins v. Board of Adjustment, 3 N.J. 200,20506, 69 A.2d 708, 710 (1949) (Polsky 1975: p.995, italics authors'). 
Progress in Planning

A third example was offered by Cappel (1991):

Zoning is the most pervasive and familiar form of local government control over land use. In a zoned legal regime, land is divided into geographical districts or zones pursuant to local ordinance; municipal regulations then specify the types of land use permitted within each zone. Zoning ordinances typically regulate matters such as maximum building mass and height, location of a building on its site, maximum density of residential construction, and whether land can be used for residential, commercial, or industrial purposes (Cappel 1991: p.617, italics authors').

Some examples offered by planning and public bodies, in chronological order, are the Great Barrier Reef Marine Park Authority (1982); Jones (1990); Macintosh, Phillips, and Clough (2002); Stark County (2005); Hall County Board of Commissioners (2009); and the Planning Institute of Australia (2014), formerly the Royal Australian Planning Institute.

The Australian Great Barrier Reef Marine Park Authority defined a zone clearly in terms of an area and its uses. The word "delineation" was not used, but implied.

Q17: What is a "Zone"? A Zone is a named area of reef, sea floor, air space and water within which certain activities, uses and access are regulated (Great Barrier Reef Marine Park Authority 1982: p.7, italics authors').

The specification of areas and specific regulations are elements of a definition by another maritime study:

Zoning is a form of land use control that has long had application in the field of town planning, where it has served traditionally to regulate certain activities, essentially construction and other works within a specific area (de Klemm and Shine 1993). Zoning is usually achieved by means of a plan drawn up for an entire administrative unit of territory, usually a municipality. Per de Klemm, C. and C. Shine, 1993. Biological Diversity Conservation and the Law. IUCN, Gland, Switzerland and Cambridge, U.K 292p.) (Macintosh, Phillips, and Clough 2002: p.19, italics authors').

An American Planning Association publication by Jones described zoning:

In most cities of any size, each and every parcel of land has been designated by the local government with a certain zoning category, which identified what uses are permitted (and, 


\section{Progress in Planning}

in effect, what uses are not permitted) on that piece of land (Jones 1990: p.50, italics authors').

A parcel of land is land demarcated.

The Hall County Board's definition spelled out the concept of mapping and the separation of uses.

Zoning is the practice of specifying different uses for land based on zones, which are mapped out separating one set of land uses from another. The rules for the zones are placed on the property by the County Commissioners. They may include a wide range of regulations that detail the allowable uses for the property, commercial versus residential use, access, building height, hours of operation, lot coverage, materials for construction or buffers against adjacent uses and many other conditions that deal with the type of uses and buildings that people want or expect to see being built next door to them (Hall County Board of Commissioners 2009: p.1, italics authors').

Likewise, the "Stark County Rezoning Application Directions, A Zoning - Update, 2005" gave a definition that included mapping and land use designation:

Zoning is a system of land use regulation that controls the physical development of land. It is a legal mechanism by which local government is able to regulate an owner's right to use privately owned land for the sake of protecting the public health, safety, and/or general welfare. Land is mapped into different zones with the primary purpose of promoting compatible land uses and to separate incompatible uses (Stark County 2005, italics authors').

The current official definition of zoning on the website of the Planning Institute of Australia contains elements of partitioning land into smaller areas and the land uses prescribed for these areas.

Each Council area is divided into a number of smaller areas in the Development Plan, which are called "zones". Zones are used as a way of grouping areas with similar characteristics such as land use together and setting outcomes for the area through policy. Zones are typically based on land uses such as residential, industrial and commercial. The policy that is included within each zone in the Development Plan then reinforces the type of zone. The way zones differentiate from one another includes defining the types of uses that are not envisaged or encouraged in the area, e.g. in a residential zone housing will be encouraged but industrial developments will not and vice versa (Planning Institute of Australia 2014, italics authors'). 
Progress in Planning

Some definitions of zoning adopted in academic studies that fall within the second type of definition include those by Wheeler, Fittipaldi, Forrest, and Marlatt (1988); Stoddard (1987); Ko (2009); and Micelli and Faggiani (2001).

The definition of zoning by Wheeler, Fittipaldi, Forrest, and Marlatt (1988) is typical of the second type of definition:

Zoning: First, what is "zoning"? In the most basic terms, zoning is the separation of land uses into categories of similar uses and the regulation of those uses within each category. In the United States, local government zoning ordinances are based on the state enabling legislation which authorizes those governments to zone. Almost without exception, those state enabling acts are based on the 1926 (rev. ed.) Standard State Zoning Enabling Act (SZEA). As its authors stated, that act was intended to: "lessen congestion in the streets; to secure safety from fire, panic, and other dangers; to promote health and general welfare; to provide adequate light and air; to prevent the overcrowding of land; to avoid undue concentration of population..." The fundamental premise of zoning is that uses which are incompatible with each other, for whatever reason, should be separated to avoid damages to each use from that incompatibility. The best example of conventional zoning is an official zoning map which covers the entire...Page 9 (Wheeler, Fittipaldi, Forrest, and Marlatt 1988: p.1988, italics authors').

Relying on Ervin et al. (1977), Ko's (2009) definition was also a form of the Abercrombie expression: partition of land into areas and specification of uses/activities:

Zoning is a universal form of development control. It may be defined as the practice of dividing a land area into districts within which only specified activities may take place (Ervin et. al. 1977). Zoning may also be considered as the main legal instrument for the control and ordering of the production and of the appropriation of the built environment (Luciana Corrêa do Lago 2006) (Ko 2009: p.6, italics authors').

The same is true of Micelli and Faggiani's (2001) definition, which, like that of Wheeler, Fittipaldi, Forrest, and Marlatt (1988); Lai (1999); and Stark County (2005) mentioned above, also specified the internalization of externalities as an intention:

The planning technique of the zoning can be defined as a device for regulating land use within a spatial area and it represents a tool through which a community can deal with the 
Progress in Planning

externalities raised by the physical and spatial interaction typical of the city or region contexts (Micelli and Faggiani 2001: p.3, italics authors').

Foy's (2012) definition is a recent example of this type. Abercrombie's concept of dedication was expressed as designation.

Zoning is the method by which governments designate which uses can be permitted in a given area... (Foy 2012: p.30).

The work of Stoddard, inspired by Wickersham (1981), is an example of the third type of question, focusing on the categorization of uses into classes or groups:

Zoning...group different land uses into a few broad categories...per Wickersham (1981) (Stoddard 1987: p.17, italics authors').

Wills' (1980) earlier and useful textbook on the economics of planning mentioned in passing the nature of zoning in terms of its purposes:

...to eliminate those external diseconomies that the construction of 'undesirable' property features may impose upon other properties in any given zoning district. Zoning seeks to minimise total external effects by separating land uses (Wills 1980: p.80, italics authors').

Alexander's (1992) definition in his process approach to planning pinpoints the functional separation and restriction of uses in urban areas:

Zoning, that is the regulation of urban development by separating and restricting urban areas by function, spread from New York throughout the land (Alexander 1992: p.29, italics authors').

Although separation and restriction in the description may involve lines marking limits, the delineation of boundaries is not explicit.

Stoddard's, Wills' and Alexander's definitions can be a first or second type of question that pinpoints the concept and practice of grouping several land uses into an element of zoning.

\section{Lessons learnt}


Progress in Planning

At least three important lessons can be learned or inferred from the survey of mainstream planning literature above.

(a) Boundary delineation as the essence of zoning

First, the most important feature of zoning should be boundary delineation. The purposes, characteristics, and consequences of zoning may differ from place to place, change from time to time, and vary due to different institutional arrangements. The variations are in a logical sense accidental. However in a modern context, without a clearly defined boundary no zone is tenable, as that is definitional, if not ontological.

Inspired by Lafferty and Frech III's (1978) idea that "the entire town is a zone" and drawing attention to the neglect of the spatial dimension in research on property rights at the time, Lai $(1994,1997$ : p.234) advanced the argument that boundary delineation is an essential element of zoning at various levels from the politicaleconomy level of state border demarcation down to district level matters like town planning and traffic management. Although zoning can be done without much planning, spatial planning - good or bad, private or public, deliberate or incidental - cannot be done without zoning.

Therefore, all planning jurisdictions are, in fact, zoned, although officially, they may be called "non-zones". This is the true meaning of Punter's (1999) careful description of the absence of zoning in America:

There are as many local government units which do not administer zoning at all as to emphasize the absence of controls over much of the country... (Punter 1999, p.5).

Unlike its American counterpart, which has a finer differentiation of zones within a local planning area and, hence, is known to be a zoning regime, the British system is one of zoning by local government, which 
Progress in Planning

treats the entire local government area as one zone in which all redevelopments and changes in use other than exempted categories need prior permission.

Colonial Hong Kong imitated this British approach and introduced the concept of "Development Permission Areas," within which all new developments and changes in use need approval by the Town Planning Board (TPB). Houston, represented in the title of Siegan's (1970) seminal paper as a "non-zoning" city, was, in fact, not entirely free from government zoning. The state of Texas generated land parcels demarcated by roads and controlled its subdivisions and road developments. (Recall the question in Part 2 in relation for provision of railways and public roads. Public roads are typical zones used by the modern state the bounds of which (i.e. the verges) demarcate urban and suburban private property boundaries.) What was absent was merely a government plan that was expressly called a zoning plan. Houston, as explained below with reference to authorities in law, was a case of "private zoning," though Cappel (1991) called it "pre-zoning" in the same way he described New Haven.

(b) Two assumptions: zoning as a state planning method and zoning as imposed unilaterally by the state

Secondly, apart from the important point that zoning necessarily involves spatial demarcation or delineation, the works reviewed above generally have two presumptions that are theoretically worth reconsideration.

The first presumption is that zoning, as boundary delineation, must be a government or public thing. The second is that the state can only zone by edict. The first presumption can be rebutted by examples of private zoning and other forms of zoning by contract. All these examples are well-researched demonstrations of the 
Progress in Planning

usefulness of mutual consent to development using common law devices without any imposed zoning legislation.

While no private plan is completely free from state input, as argued above, private zoning on a scale and quality as good as, if not superior to, state zoning does exist. Development control by restrictive covenants in Houston is a case in point. Houston's system can be more precisely described as a form of private zoning by agreement within a broad land system zoned by state roads. Both state and private zoning were involved, although the former was infrastructural rather than regulatory.

Another good example of private zoning in the absence of state planning legislation is the creation of leasehold estates out of freehold estates. Some basic private planning in terms of defining the areas, road access, land use, and building codes is often involved. A good reference is the work of George (2000) on Liverpool Park Estates in Britain. Today, private zoning in the presence of planning legislation continues with large sites under private ownership. The layouts of these sites, typically designed by developers and approved under the state planning system, usually designate different areas for different uses or activities.

Private zoning can also happen in the absence of planning legislation, but only with government approval on a consensual basis. In a nutshell, zoning need not always be brought about by legislation or the unilateral dictate of the state and indeed, on our earlier argument in part 1, may even be a natural feature of pre-state communities. The case of "non-zoning" in Houston, where control of development was by way of restrictive covenants, was truly one of "private zoning," which is a term of art in legal research. This can be found in the title of such works as those by Lundberg (1973), and Shepard (2011) and was cited in the texts of Urban (1973); Ross, Smith, and Pritt (1996); and Stringham, Miller, and Clark (2010), among many 
Progress in Planning

others. The persuasive Gordon and Richardson (2001) and the much cited Deng (2003) adopted the term in their planning studies.

The expression, "private zoning," to the best of the authors' knowledge, was first used in the 1958 issue of Wisconsin Law Review to describe the case of Milwaukee by Beuscher (1958) as a preface for the subject matters of two excellent articles by Consigny and Zile (1958) and Zile (1959). The last two works explained how restrictive covenants controlled land use in Milwaukee before state zoning legislation came along. Although "both articles should be of interest to lawyers, land planners, land economists, students of urban problems, land developers and just plain home purchasers" (Beuscher 1958: p.611), the case of Houston from Siegan's (1970) point of view was far better known.

Urban (1973) wrongly claimed that "Houston is the only area that has anything like 'private zoning.'” (1973, Fn4, p.1656). Two important findings of Urban's legal treatise were that the common law courts in the U.S.: (a) regarded restrictive covenants as a means of "private zoning" and (b) imposed rules for zoning laws to nullify those covenants that violated public planning law principles. Cappel (1991) described private zoning in New Haven to be one of "prezoning". This was probably due to the fact that neither Consigny and Zile (1958) nor Zile (1959), not to mention Milwaukee, were mentioned in Siegan's (1970) work or in the aforementioned works on private zoning. To be fair, Siegan's (1970) work inspired a host of well-documented case studies on "private zoning" by means of restrictive covenants, notably in New Haven by Cappel (1991) and Celebration, Florida by Stringham, Miller, and Clark (2010).

Note that the private zoning cases of Milwaukee (Consigny and Zile 1958; Zile 1959), Houston (Siegan 1970), New Haven (Cappel 1991) and Celebration (Stringham, Miller, and Clark 2010) did not involve the state playing an active planning role by means of legislation. This 
Progress in Planning

did not mean that private zoning cannot involve the state to deal with private parties on commercial principles without resorting to its legislative faculty. In a leasehold land system, the relationship between the state and the developer can be contractual and on equal footing. A good example is the development of Discovery Bay on Lantau Island, Hong Kong. (Lai, Davies and Lorne 2015)

During the late 1970s, the developer, Hong Kong Resort Co. Ltd., bought land under agricultural leases and obtained government consent to open up the land for residential, commercial, and golf course development. The property was cut off from the rest of Hong Kong in terms of road transport and the only access to the land until 1997 was by sea. The government provided no infrastructural support and the developer had to form sites and build a large reservoir, piers, seawalls, etc. All development had to be in accordance with a master layout plan agreed to by the land authority, the District Office (later District Lands Office), the decisions of which, unlike with the Town Planning Board (TPB), could not be subject to judicial review. The result has been a clear commercial and planning success. A private and well-planned community with a large expatriate population has grown up on Lantau in phases. In 2000, the TPB imposed the first statutory town plan on the whole settlement. This is an example of what Lai $(1996,1998)$ described as "zoning by contract" or "zoning by consent".

Another more interesting example of private zoning under common law, which dated back to 1921, can be found in Colonial Hong Kong. It was significant because the mechanism was not one by restrictive covenant or lease term, so it was different in terms of institutional arrangements from "pre-zoning" in Cappel's (1991) sense, "non-zoning" in Siegan's $(1970,1994)$ sense, or "private zoning" in the sense of Gordon and Richardson (2001). 
The example in question is one in which a private board of directors that governs shareholders as owners of houses in a private company achieves zoning via their decisions. As reported by Lai and Kwong (2012), the Shek O Development Company Limited (SODCL), a private limited company formed in 1921, bought a piece of leasehold land from the Colonial Hong Kong Government for the express purpose of promoting the sport of golf. Shareholders were entitled to build a house subject to the board's approval, while altering and alienating the property required the prior permission of the same board, which operated like a private government. The fundamental difference between a state price control and planning or building board and this SODCL board of directors was that submission to the latter was voluntary since it was the result of individual decisions to buy (or, more properly speaking, being allowed to buy) shares in SODCL. The property values of the SODCL houses, saved from the usual tendency to increase the density of land use by transforming properties into apartment blocks, far exceeded any house elsewhere in Hong Kong.

(c) Zone boundaries are treated as decision variables but lot boundaries as non-existing

All works examined deem zone boundaries as policy variables subject to modifications. That is true by definition, However, other than those of Lai $(1994,1996,1997,1998)$, none the works examined above mention private property boundaries in relation to the government zoning boundaries, nor any issues pertaining to the delineation of the latter regarding say exactitude or scale. It would seem as if the question for each government planned zone is designed for one single owner or unit of land use within exactly the confines of that zone.

\section{Part 5: Scenarios of zoning}


Progress in Planning

The literature review affirms that modern zoning involves boundary delineation, though the relationship between the boundaries of planned zones and private lots is under-researched. Equally, although most scholars see zoning only as a government activity, Part 3 shows that zoning, and the attendant boundaries, is also an outcome of other, non-government arrangements. In all cases the state plays an important part, via zoning of one sort or another, in defining and redefining property boundaries. The following discussion of scenarios of zoning is Coasian in the sense that these boundary issues are not trivial in theory or practice and have significant transaction cost implications. It is also Hayekian in the sense that the role of information discovery is involved. The state is visibly involved, as the delineation of boundaries has at least traditionally had a military or at least state provided security connection. ${ }^{19}$

Private property involves exclusivity and, hence, state protection against incursions, implicit or actual, via the state's monopoly of "organized violence". In fact, in many instances throughout history, although possibly as a by-product of its more specifically military concerns, the military was often the best equipped for and involved in the demarcation of initial private property boundaries and the establishment of a geodetically integrated land system ${ }^{20}$. But this political economic interpretation of zoning, as backed by the might of the state, is less significant than its role in subsequently attenuating, assigning/reassigning, conferring, expropriating and returning private property rights, their efficiency in terms of transaction costs and more particularly in their informational implications for transaction costs.

\footnotetext{
${ }^{19}$ It is worth noting how late in human history the distinction between the military and the police functions of the state's monopoly of organized violence manifested itself in organizational terms. Indeed in many states the distinction is still blurred, as in France, for example, where one part of the 'police' force, the Gendarmerie, remains part of the Ministry of Defence. In colonies like Hong Kong the distinction was never fully institutionalized, colonial police forces being manifestly paramilitary in appearance, organization and relationship to the civilian population.

${ }^{20}$ For Britain, see Hewitt (2010).
} 
Progress in Planning

These factors are summarized in the scenarios with their implications for the market in Table 1. The focus here is on zone boundaries, which hitherto have received far less attention than other planning concerns considered as substantial.

\section{Table 1: Zoning Scenarios and Their Transaction costs and Informational Dimensions}

About here

Caption for Table 1: Zoning Scenarios and Their Transaction Cost, Informational \& Innovative Dimensions

\section{Scenario 1: Conflict of zoning}

When the state planner imposes a new zone on existing private properties, the conventional neo-institutional economic analysis would focus on the attenuation, if not nullification, of the freedom of the land owner, in terms of her/his exclusive rights in using, deriving income from or alienating the land (Lai 1997; Webster and Lai 2003). Such attenuation is either addressed in terms of freedom of property; evaluated as an empirical question as to whether or not and to what extent the zoning actually enhances or reduces property values (Lai 1994); or it is interpreted as a rent-seeking or rationing mechanism with social/class segregation intent and implications (Perin 1975). In either case, the issue of compensation for regulatory takings, down zoning (or "regulatory zoning") (Fischel 1995; Alterman 2010) and betterment is frequently a political bone of contention.

It is not the purpose of this monograph to be involved in these econo-political or socio-economic debates. Rather it draws attention to the phenomenon that the boundaries of the former - a state imposed zone - may not and often do not correspond neatly to those of the latter - private lots. Nonetheless prescriptions for the land the former happen to enclose prevail over any property rights of the 
Progress in Planning

latter if they are in conflict. A good example of this would be where an existing private lot is partitioned by new zone boundaries. The property is thereby separated by the two zoned uses imposed on it, necessarily forcing a fragmentation of use for the private site. This was exactly the factual background of Euclid v. Ambler Realty where a private lot was traversed by a line drawn by the government planner which divided the site into an industrial and residential area with the outcome that the property owner was disallowed using any land on the site for housing for fear of industrial pollution. If such a mismatch is unintentional (i.e. not for a specific and necessary planning purpose), then it would be a source of extra transaction costs, and hence inefficiency for any private property development. Such an unintended mismatch, in which the state planner creates information confusion for property owners, is due mainly to the planning processes lack of understanding about or care for pre-existing property rights. This is a typical knowledge problem confronting the state stressed by Hayek $(1944,1960)$ and compounded by the practice tradition of the modern government planner to plan on small scale maps ignoring lot boundaries. In Coasian terms, transaction costs of information are far from zero. Theoretically, the state planner can avoid or rectify this, but the trouble is that $s /$ he has no incentive to do so and the speed of rezoning is faster than any rectification attempt. Figure 5A shows an example of conflict of zoning in which a planned zone imposed on private lots divides a lot into two parts.

\section{Figures $5 \mathrm{~A}$ and $5 \mathrm{~B}$ about here}

Caption for Figure 5A: Conflict of Zoning (Forced Division)

Caption for Figure 5B: Conflict of Zoning (Forced Combination)

Another example of conflict of zones due to boundary problems is the reverse of subdivision and is intentional. A much bigger zone is imposed to neatly envelope several target private 
Progress in Planning

properties and a development control requirement is imposed. Expresssly to avoid piecemeal outcomes, redevelopment of the zoned area is thus only possible when it is done en bloc. This situation is shown in Figure 5B. This type of zoning is often a prelude to takings when the purpose is urban renewal, as transaction costs of cooperation of all owners to produce a joint redevelopment scheme are often prohibitively high and the state has an excuse to use its prerogative to confiscate private property. To an owner who indeed wants to redevelop, his/her decision would be contingent on the consent and cooperation of all neighbours whose land parcels are unilaterally bundled by the state. The uncooperative owners are often accused of "holding out" when in fact the state is creating the problem by imposing a new constraint on the exclusive freedom of use of one's land. The situation in terms of property values is worse than zoning all properties to preserve them as built heritage, and certainly different from the scenario in which landowners voluntarily enter into a treaty with adjoining property owners to subject individual use, income and alienation rights to collective decisions as in the case of SODCL seeking to enhance collective property value by maintaining a holistic architectural and life style. As in the previous case, "Changing zoning is a difficult, alienating, time-consuming and expensive process" (Mundy and Lane 2011: p. 567) in terms of transaction costs.

The mechanism "transfer of development rights" (TDR) is in this context pertinent to a discussion of conflict of zoning. In the property rights and planning literature, TDR has been discussed and applied with a view to untie the value of a property from its original boundary confines, thus achieving savings in various kinds of transaction costs 
Progress in Planning

such as those for compensation calibration, political articulation and violence. In practice, it can mean:

(a) a property owner may transfer land coverage, (residential) development rights, and (residential) allocations from one part of a site he owns to another part of the same site (Maraist 1995) or to another site;

(b) on elaboration, a predetermined maximum level of development within a specified region is distributed as "development rights" landowners within the region such that landowners who keep their development levels below their allotted development rights level can sell their surplus development rights to other landowners, or they can use them to offset development on other properties (Shogren et al 2003);

(c) a way used by the state to compensate a land owner deprived of his property by exchanging with him another piece of government land of comparable economic value by mutual agreement; or

(d) a tradable and redeemable land certificate which can be used to obtain a certain ratio of new sites planned and serviced by the state.

Methods (a) and (b) simply make an un-exploited development potential under a state cap transferrable and hence more efficient than a situation where such transfer is not allowed. In the words of John Costonis the pioneer in this concept, "Development rights transfer breaks the linkage between particular land and its development potential by permitting the transfer of that potential, or "development rights," to land where greater density will not be objectionable." (Costonis 1975: p.85-86. Italics authors). Though economists agree that this is "efficient" (Innes 1997), private property rights are attenuated without due compensation. Renard (2007) questioned the concept of TDR as it rests on the contentious 
Progress in Planning

assumption that a private property owner has "a right to capital gain even if this gain is the result of the general evolution of urban growth, including the construction of infrastructure by public authorities, without any activity of the landowner." This view is in the vein of Henry George and certainly does NOT apply to jurisdictions where there are fiscal betterment levies or "lease modification premia". In any event both (a) and (b) met with limited success in the US (String et al 1996). Method (c) is the real TDR that satisfies the compensation principle. This mechanism is fair and is justifiable especially where the land surrendered is to be conserved for its heritage or scientific interest.

One application of Principle (c) of TDR is for what planners call "land adjustment" (Liebmann 2000, Xu et al. 2015), which seeks to regularize private land parcels of irregular shape into rectilinearshaped units for a modern layout. Conceptually a modern application of the surrender and re-grant concept, land adjustment reduces the transaction costs of the use and commodification of land, while conforming land boundaries to modern transport routes and development designs.

An actual successful case of TDR by way of method (d) was the issue by colonial Hong Kong of a transferrable "Letter A" ("Letter B") for voluntary surrender (forced resumption) of agricultural land. This can be used to either (a) purchase a certain amount of urban land in any future government land sale by auction or tender; (b) obtain an annual payment according to a schedule; (c) surrender the land to the state for a redemption sum. These Letters $A / B$ were used to efficiently collect farmland for new town development, predicated on modern zoning plans, in which such letters were used by developers 
Progress in Planning

to participate in private development. They lowered the transaction costs of peacefully freeing land locked up in a mosaic of irregular shaped lots owned by villagers who could no longer rely on cultivation to make a living.

\section{Scenario 2: Borderline non-zoning}

Zone and property boundaries are lines. Conceptually, as we have noted, lines have no thickness. But unless such lines are entirely and closely based on property boundaries as shown on the largest scale topographic survey maps, when they are plotted on a small scale cadastral or zoning map, some small properties that look big enough to accommodate a house or supermarket can actually encroach on these lines. Any such encroachment, whether small or large, may leave it uncertain as to which zone affected properties belong in.

This is what often happens to land in rural areas, where small properties tend to be located. In Hong Kong, the zoning map of an Outline Zoning Plan for the urban area is typically drawn to a scale of 1:5,000 but a Rural Outline Zoning Plan for the suburban and rural area is to a smaller scale of $1: 7,500$ to 10,000 . A "small house" exempted from the Buildings Ordinance, measuring 20 feet times 35 feet, can stand partly along a zoning line on such a map. If we assume a mean of 1:8,000 for the purpose of a calculation, on a plan to that scale 20 feet is represented by a line $3 / 100^{\text {ths }}$ of an inch long and 35 feet by one $21 / 400^{\text {ths }}$, a dot on the map exactly .0825 sq.in. Even on the 1:5,000 plans, the 'dot' is just 0.132 sq.in. So confusion is not unknown. ${ }^{21}$ Figure 6 shows an example of this scenario.

\footnotetext{
${ }^{21}$ See Metro Planning Committee Paper No. A/H14/55 on 28 Barker Road, the Peak. Town Planning Board, Minutes of 370th Meeting of the Metro Planning Committee held at 9:00 a.m. on 28.3.2008.
} 
Progress in Planning

\section{Figure 6 about here}

Caption for Figure 6: Border Line Zoning

The origin of this phenomenon, as explained in Part 2, is the use by government planners of small scale maps in planning. Again, the state planner can overcome this information confusion problem by providing a large scale representation of these boundary lines and a boundary commission to resolve disputes. Due to the great advancement in digital technology, such an approach would no longer incur extra, prohibitively high transaction costs. The question is whether the government planner is willing so to act given established practices and, to the government planner, the perceived transaction costs for the planning system of instituting new practices.

Taking up on the earlier point about the penumbrality of zoning, in a sense borderline non-zoning is an inevitable planning hazard because the mental approach of a 'zoner' is by definition indifferent to any fractal irregularity of both the land and land-occupancy. To use a common nautical phrase, small properties near zone boundaries cannot but be at risk of "falling through the gaps in the planking". The metaphor makes the point that on a planked deck, or floor, a seamless joint may be an ideal, but even were the time that must necessarily be spent in better fairing plank edges to be economically feasible, a perfect fit is not possible. Caulking is thus a given. Zones, in that sense, 'plank' the 'deck' of the ship of state and it is no business of those who lay the deck - the planners - to worry unduly about gaps and irregularities in the seams that may cause leaks that vex the huggermugger of bunk spaces in the steerage accommodation below. Where the planks prove to leak, causing inconvenience and damage to the property of those below, that is the job of the caulker to fix, or, to escape the metaphor, the job of lawyers, appeal board panelists and 
Progress in Planning

judges. The analysis points to the need to enrich transaction cost vocabulary by calling these "boundary costs".

\section{Scenario 3: Incomplete zoning}

A boundary is a technically closed loop. In any case where a private property boundary does not form an unambiguous loop, the property is incompletely designated. This could happen, given the simple Coasian reason for this is that the state does not have perfect information, when one side of the property is legally contested or uncertain, as in the case of any maritime or riparian border of a site. A situation of commons arises in the space along the waterfront if, as is sometimes the case, there is a lack of boundary precision. Such lack of precision can result from seashore related boundaries resting on potentially uncertain metrics. Typical of these would be the once decidedly ill-fixed "Sea at High Water Mark". 22 Perhaps most vexatious would be cases where the exact azimuth of the sea shore at the point where the line of division between one marine lot and the next reached the sea could not be exactly determined because of the uncertainties noted. For without an exact azimuth of the line of the shore boundary at the boundary between properties, the 'correct' azimuth, at right angles to the shoreline, of any extension seawards of the lot dividing line would be uncertain, and hence the allocation of riparian rights of any kind, would not have been exactly determined.

In the first case we can generalize by noting that where the shore boundary is uncertain, landowners will tend as a result to consider the real border of a lot as lying as far out into the water as practically possible. They will accordingly carry out land reclamation as a rentseeking response. This creates transaction costs as a result of

\footnotetext{
22 The full theorization of tides was not achieved until Doodson's (1921) work. See Chapter 11 in Cartwright and Melchior (2001) and in Hong Kong, a final settlement of the High Water Mark had to wait until a full, 19 year run of observations was completed in 1989.
} 
Progress in Planning

disputes with adjoining owners and/or between the state and individual owners. Legislative intervention is required to complete the loops.

This was a particular problem in early colonial Hong Kong where the first 50 Marine Lots, sold by auction on 14 June 1841, were tightly defined only on their landward bounds by a road, each with 100 feet frontage on the sea and 100 feet on the road (Sayer 1980). The result was an extension of the lots to seaward at the least cost to lot owners, who significantly expanded their lots where the foreshore bound was only loosely defined. The government's object, once these problems arose, was to replace the shifting, privately controlled foreshore by a publicly owned road fronted by a seawall between Marine Lots and the sea, thereby 'closing' the previously loosely demarcated private property loop by a clear bound between public and private property. At the same time, by creating a definitive sea-edge boundary, government could accord marine lot leaseholders' rights at that boundary, such as rights to land goods and passengers, to construct approved landing piers, etc. Figure 7 illustrates this form of incomplete zoning. The government solution to run a road along a reclamation to delimit the seaward frontage of the lots.

\section{Figure 7 about here}

Caption for Figure 7: Officially Forgotten Zone

The Foreshore and Sea Bed Ordinance of 1901 was introduced not only to stop marine lot owners from privately creating new property through reclamation, but also to secure the quality and durability of the sea wall defences, affirm the public right of access to the foreshore, create the conditions for precise foreshore lot delineation and, therefore, definitive loop closure for waterfront properties. The effect of the Ordinance was to differentiate Marine Lots into "Class A" 
Progress in Planning

and "Class B" Lots, but in so doing strictly to define their seaward boundaries and the rights with respect to the foreshore each type had.

"Class B" Marine Lots merely had their frontage on a public road that ran along the sea shore. Other than in name they did not differ from any ordinary Inland Lot. No rights obtained to such a leaseholder to access to the seashore different to the rights of all other members of the public.

There remained "Class A" Marine Lots, which had a public road between them and the sea. These were largely an historical hangover from Hong Kong's early days, but because they did once have a sea frontage abutting the sea, such lots were accepted to have additional rights. These were summarized as, ${ }^{23}$

"subject to the public right of navigation of the sea and harbour, and fishing therein, a private right of access to the sea or harbour, and a right to bring vessels alongside their Lots or portions of Lots, and to discharge and load cargo there, and to embark and disembark there. In the exercise of this right there must be no unnecessary or unreasonable interference with the public right."

Lastly came such Marine Lot holders as operated shipyards, docks and slipways. These are and remain a special case and, for the purposes of clarity of boundaries, have their terrestrial properties extended to include a delineated area of seabed, thereby negating any uncertainty of boundary location occasioned by changing tidal data or changing global sea levels - the latter today a matter of significant concern given the expectations of the consequences of global warming.

\section{Scenario 4: Officially forgotten zones}

${ }^{23}$ Government of Hong Kong (1931: para 32). 
Progress in Planning

When de facto zones that exist in the memories of a social or ethnic group are denied by another group that holds power, the question of officially forgotten zones emerges. Relevant information on these places is disregarded by the state. Naturally, a conflict of zones, which may well frustrate or raise the transaction costs of private development, according to the official zone boundaries, emerges. This is a case of the state misinforming de jure owners. Typically these owners seek the court's assistance and the court tends to recognize only de jure rights, so this does not solve the problem. Huge political transaction costs in bringing about a satisfactory solution, often through legislation that compromises the de jure rights assigned by the state, may be reached. One can find excellent examples of this problem in the indigenous land rights issues in such jurisdictions as Canada, the USA, New Zealand and Australia. Figure 8 demonstrates a possible officially forgotten zone which contains an official zone. How to recognize and treat the tribal shrine beyond a matter of "archaeology" or "heritage" in respect of any surviving claimants to the forgotten zone, bearing in mind existing de jure property owners is a difficult socio-political question. Reversion of rights is often impractical and in any case the property owners, treated as squatters, must have some rights to the land they possess.

\section{Figure 8 about here}

Caption for Figure 8: Incomplete Zoning

In the New Territories of Hong Kong outside New Kowloon, a major forgotten zone exists in the minds of the leaders of so-called recognized indigenous villagers who often feel aggrieved by modern statutory zoning for Country Park or other basically conservation uses as a means to expropriate their original, pre-colonial, land use rights. Most of the villagers, under customary Chinese land law, were "land skin rights holders" (tenants) leasing land from absentee "land bone 
Progress in Planning

rights" holders, who paid the Imperial government a fixed land tax. ${ }^{24}$ The British Government ousted the land bone owners and collected land taxes directly from the villagers who were mostly land skin rights holders, who were granted rights as Crown lessees under Block Crown Leases. (Lai et al 2015)

Adopting the common law stance of the British colonial administration, the post-colonial Special Administrative Government considers the grievance as a legal nonsense, as the spatial confines of their land rights had been exhaustively delimited in the Demarcation District Lots Sheets that accompany Block Crown Leases recording land uses and buildings as surveyed at the turn of last century. To allow for expansion of the surveyed villages, in the wake of a gigantic new town programme which has transformed the New Territories into a residential and industrial region, the District Office of the colonial government in 1972 defined for each recognized village a "village environ" with its perimeter being 300 feet away from outmost edge of the outermost lawful village building as found in 1971. Occasional grants of Crown Land have been made from time to time but the approach has been cautious and small in scale, typically to resettle a village affected by public works. The village environ zones are restricted government information not disclosed to the public though the cores of most of these have been designated Village Type Development $(\mathrm{V})$ zones on statutory town plans.

The mental map of the village leader does not however correspond to the zonal boundaries of either the "village environs" or V zones. To

\footnotetext{
${ }^{24}$ No residual land bone rights were allowed to subsist except those on Cheung Chau, for unknown policy reasons, which the colonial government recognized as legitimate. The Wong Wai Tsak Tong, a body corporate recognized by the colonial administration, was allowed to collect rent from all private land on the island of Cheung Chau. The government passed an ordinance Block Crown Lease (Cheung Chau) Ordinance in 1995 to terminate the Block Crown Lease granted to the Wong Wai Tsak Tong so as to resolve the disputes between the Wong Wai Tsak Tong and the sub-lessees and made compensation.
} 
him, always a man by tradition, the real village area appears to stretch well beyond the outmost limit of cultivation area, which encircled the village environ delineated in 1972. He sees that 'real' area as he imagines it to have been at the time of the leasing of the New Territories from China. It ends, vaguely, where potential expansion would be opposed by neighbouring villages. This is so because land bone rights holders would not bother or object to expansion of the territory of cultivation or any other activities ("doing whatever we like") by land skin rights holders provided the agreed land rent was paid. That is, there was no practically entailed contiguity between the de jure actual boundaries of the registered land bone rights and those de facto of the unregistered land skin rights. If this seems difficult to grasp, imagine a closed umbrella where the 'skin' (no matter a rumpled one) clings tightly to the 'bone' of the umbrella shaft. If the umbrella is opened - the skin rights holders expand the land under cultivation - this has no effect on the area of the bone unless there is some sort of official reconciliation of the respective areas: a transaction cost the Qing regime's officialdom was in general disinclined to incur.

There is a need here for some elaboration of the Imperial Chinese way of surveying and registering rural land. The famous Ming Dynasty "fish scale atlas" for recording registered land for tax purpose was only a topological representation. Land area, the basis of taxation, was clearly recorded. However, the transaction costs of monitoring illegal unreported expansion of farmland were well known to officialdom. In consequence they turned a blind eye to any such expansion as rectification would incur the even greater transaction costs of enforcement (especially against those with vested interests inside a bureaucracy almost identical to the literate gentry class), and, possibly, a resultant local uprising. Similarly, the registered land owner did not cultivate. He leased his land (registered or otherwise) to tenants at a rent which, in the Manchu Qing Dynasty, became 
Progress in Planning

"fixed forever" as all emperors honoured the promise and will of Emperor Hong Hei (Kangxi, 康熙) made in 1713 to never increase tax rates. The landlord (i.e., the land bone rights holder) did not bother to check whether and how much land the tenant (i.e., the land skin rights holder) cultivated and only cared about rent collection. Unreporting of land cultivated under this system was massive.

What evolved was a nominally pro-rata levy based on land area under cultivation but a de facto fixed tax paid by the rent-collecting land bone rights holder, who played the role of insurance against the risk of bad harvests (and hence inability to pay tax) of the land skin rights holders. Though surely individual land skin rights owners knew the de facto spatial limit of the land they possessed, they took for granted that opening up the wilderness was legitimate "as the landlord would not bother." This was the state of affairs before the commodification of land, when land (its fertility) was an input to production rather than an investment good. China's first modern cadastral survey was done 1 year before the downfall of the Manchu Empire in 1911, likely with a fiscal revenue intent, and it is a good question for the historian as to whether this land auditing exercise had to do with the success of the Republican Revolution.

Although it is not entirely clear what the actual extent of land bone rights was (i.e. where the boundaries of a 'land bone' lay ${ }^{25}$ ), it can be presumed to be, as in the case of the village leader's assumption above, at some ill-defined point well-beyond any extant inhabited or worked village terrain, where it meets a similar land bone rights claim coming the other way. Given that assumption, it followed that at least

\footnotetext{
${ }^{25}$ There appears to be nothing in traditional Chinese land administration that equates to the closely surveyed and mapped cadastral system as this had emerged in the western world by the time the British annexed Hong Kong. Boundaries were more a matter of customary agreement based on long-established practice retained as folk-memory as to what marked the division between any one land holding and any other.
} 
Progress in Planning

in theory land skin rights holders (let us say Village A) could extend their exploitation of the land around Village $A$ to wherever there were no opposing claims by another village. When disputes happened, villages resolved them by might, arbitration or treaty.

In the colonial context therefore, from the land skin villagers' point of view, as long as they continued to pay land tax to the British Crown AS IF the Crown were land bone owners to the Manchu Emperor, they believed that they should be allowed to enjoy their customary land rights to "reclaim land from the wilderness" to some social limit, despite these having been long extinguished by the inception of common law. Putting that into the language of zoning, we may say that Hong Kong's traditional villagers assume a zone, their village zone, within which they may extend cultivation or allocate land for residential development, as it suited and today suits them.

The key point here, extremely difficult to formulate in the modern language of cadaster and zone, is that NEITHER bone NOR skin was legally defined. Conceptually we have state of affairs ' $A$ ' at time ' $T$ ' in which the bone rights holder holds the bone rights to the land $(A)(T)\left(B R_{a}\right)$ on which the land skin rights holder has developed (in some sense) housing and fields $(A)(T)\left(S R_{a}\right)$. By time ' $T_{1}$ ' the land skin holder, impelled by exigency, demography, curiosity, avidity or whatever, has extended the occupied and cultivated area to reach state of affairs ' $B$ ' such that $(B)\left(T_{1}\right)\left(S R_{b}\right)>(A)(T)\left(S R_{a}\right)$ despite there being no change at all to the land bone right holder for whom always $(B)\left(T_{1 \ldots n}\right)\left(B R_{b} \ldots n\right)=(A)(T)\left(B R_{a}\right)$ unless the Imperial authority had engaged in an exercise of land holding rectification.

Obviously for the British Crown, which had created a cadaster by exact topographic survey, nothing the villager could do could (or now can) conceivably change the nature and extent of the land bone that the Crown acquired by treaty and, because of the nature of the 
Progress in Planning

western surveying system, had surveyed as in all cases being contiguous, one de facto land skin right to the next. Thus with the assumption of all land bone rights by the colonial government (except those on Cheung Chau under the Wong Wai Tsak Tong), the entire basis of traditional land holding was changed in that a traditionally passive land bone rights landlord, whose 'rights' were in some sense independent of villager actions, had been exchanged for an active one whose 'rights' were clearly laid down on a map. Much more important, therefore, the presumed 'village zone' within which land skin rights could be exercised at the whim of the villagers had disappeared into what we might call the 'total skin/bone' zone created by the advent of the government as holder of all land bone rights.

\section{Scenario 5: Zoning for non-planning: Ghettos and enterprise zones}

"Non-zoning", after the work of Siegan (1970), in the planning literature is famous in relation to the mode of planning and development in Houston. Siegan considered the use of restrictive covenants in the absence of zoning legislation or zoning schemes "non-zoning", ignoring the original de jure zoning of property boundaries, often defined by the public roads that are so primeval in private property.

The non-zoning discussed here is zoning of a place with pre-existing properties defined by the state after the event with the intention not to interfere with it. This may happen due to negative reasons, namely disputes over jurisdiction; social prejudice and economic protectionism in disguise, as in the case of ghettos for the Jews (Clapp 1986); or a lack of competence, capacity, or confidence of the state in handling a unique place for the time being. A case in point in Hong Kong was the Kowloon Walled City. 
This walled city began its life as an Imperial Chinese fort ${ }^{26}$ with perimeter defensive walls built of granite blocks with privately raised funds from Cantonese merchants after the ceding of Hong Kong Island in 1842. When the Kowloon Peninsula was annexed in 1860, the fort found itself close to the international land border of the colony of Hong Kong denoted by Boundary Street. In 1898, with the signing of the Second Convention of Peking, technically the Convention for the Extension of Hong Kong Territory and the leasing of the New Territories to the British, the fort became the only piece of land under Chinese rule within what was otherwise British sovereign territory. The lease treaty expressly provided for a Chinese official presence on condition that it did not pose a threat to the security of Hong Kong. Within a year of the lease coming into effect, the colonial administration found a pretext on which to interpret the Chinese officials in the fort as constituting a threat and duly evicted them. ${ }^{27}$

With the advent of the new Chinese Republic, from the 1920s till 1963 , save during the Pacific War period, British jurisdiction over the city was contested by the Chinese government. Before the War, an understanding had been made with China to develop the fort as a public park, the colonial government having bought out Chinese civilian settlers allowed to stay as Crown lessees for 20 years. After the War, Chinese people from Hong Kong and China moved into the city area, now stripped of its walls due to Japanese demolition for building materials for expanding the Kai Tak Airport, and built houses. They were treated as squatters and they resorted to the Peking

\footnotetext{
${ }^{26}$ Whether the site was related to a Sung Dynasty defence structure for the court when fleeing the Mongols awaits further and better research. The discovery of wells in the neighbourhood of the city in 2014 by tunneling work for the expanded Mass Transit Rail system lends definite support to the presence of Chinese inhabitants in Kowloon dating back to that era.

27 The claim by the Governor, Sir Henry Blake, was that the Viceroy of Canton was using the officials in Kowloon to encourage resistance to British rule as established by the Convention.
} 
Progress in Planning

Chinese government to resist government clearance action. The colonial administration finally acquiesced to the status quo but took steps to zone the city area by building new roads along the alignments of the demolished northern and eastern walls and to build public housing estates to encircle the city according to what was known as the "Nunnery Scheme" (Lai 2015, 2016; Lai et al 2015). The development or redevelopment of buildings within the encircled area was unrestricted by government though vertical reach of any building might not affect civil aviation control. Land use was unregulated and the government provided only postal and police services. Laissez faire was the order of the city. Before the handover of Hong Kong to China, the city dwellers were compensated and resettled, their buildings were demolished and the site was converted, at last, into a public park.

\section{Figure 9 about here}

\section{Caption for Figure 9: Zoning for Non-planning}

Figure 9 shows scenario of a zoned un-planned area. "Left alone" yet encircled by a zone boundary, it is a zone in its own right. Normally, provided there is no real Hobbesian anarchy with violence within the zone, occupants will form property rights to make living as comfortable as possible and investment possible.

The Kowloon Walled City is arguably the best real world example of non-zoning as there was neither state delineation of private land parcels nor government intervention by any subdivision, planning or building codes as in the case of Houston or Milwaukee. Another way of seeing this 'non-zoning' is to imagine an entirely zoned territory in which one specific area exists defined ONLY by the boundaries of zones contiguous to it, which boundaries are however NOT boundaries of the excluded area itself. 
Progress in Planning

Three salient points of the actual real estate development and transactions inside non-zoned Kowloon Walled City follow. First, preexisting building lines were respected in subsequent redevelopment as if they were de jure property boundaries, though they were not governed by any Crown Lease and could not be registered at the Land Registry. Second, the buying, selling and leasing of housing units was not disorderly and no reported violence was involved. Third, there was private supply of water for private use and elevators for communal use. This non-zoning of the city, spatially defining in three dimensions by the Nunnery Scheme horizontally and Civil Aviation Ordinance vertically, in which the state did almost nothing, nonetheless lent significant support to government involvement.

Unlike elsewhere in Hong Kong, the spacing between buildings within the city was far narrower because there was no public road zones and this affected natural light penetration overall living conditions. Not surprisingly, given also the non-zoning and absence of government involvement noted above, sale prices and rentals of units inside the city were $30 \%$ cheaper than comparable ones outside the city.

The Kowloon Walled City has been depicted in the literature as land governed by nobody. Yet, this does not contradict the fact that it was not forgotten. The government consciously did not govern it completely precisely because of its uncertain status - we might say its azonality or possibly, non-British zonability. Nonetheless, like every piece of land in Hong Kong, it was carefully surveyed and re-surveyed. The cadastral records and news reports and the physical form of the city within the three-dimensional spatial zones that enclosed it and its postal address kept vivid the memory of the boundary of this constitutionally disputed piece of territory. By policy informed by Sino-British diplomacy, it was a zone without zoning. 
Progress in Planning

Non-zoning may also be a deliberate and positive way to experiment with new ideas under laissez-faire as in the case of Houston interpreted as zoned $a b$ initio. Hong Kong after 1997 as a "special administrative region" of China under the "one country, two systems" policy is expressly to be this kind of experiment. What matters, given the social and political constraints, is that the boundaries of the place typically cannot expand or contract. Depending on the kind of non-intervention, though the names or labels of the zones are unimportant, the delineated areas can become notorious ghettos or successful enterprise zones. Researchers generally focus on the passive aspect of the state and treat the issue as a static matter. Few appreciate that given time and a degree of peace, stability and no undue interference, informal institutional arrangements within these zones will emerge to constrain rent dissipation and create new property rights, i.e. Hayekian 'spontaneous emergence' of social arrangements. The Brazilian favelas (Neuwirth 2006) are modern cases in point.

\section{Scenario 6: Rights conferring zoning}

While the above example of zoning may see new rights created in due course, the state often designates certain new zones, in areas without any pre-existing rights, as new private and/or public places. While the terms for new property may not be attractive, such zoning does not necessarily compromise any pre-existing right. In the real world, most land has some degree of pre-existing rights, entitlements, or legitimate expectations and the best examples of rights-conferring zones are those re-created in socialist regimes which have adopted the market economy and those that allow for reclamation from the sea. Two cases in points are the "villages in cities" in China today and the inception of the container terminal in Hong Kong. 
The "village in city" is an interesting case. Originating as a rural or suburban collectivized place with no de jure private property, it has been granted exclusive communal property rights with great democratic freedom in "making money". As such they are no "forgotten zones" or "zones for non-planning" unlike the case of Kowloon Walled City. Their inhabitants are classified as rural population and enjoy certain privileges (e.g. greater leniency in state imposed birth controls) not available to urban city dwellers but share in the financial benefits from any income earned by the village collective. The living standards, landscape and governance of these villages vary tremendously and generalization is hard. Some have taken advantage of their traditional communal buildings as architectural and cultural heritage in business and tourism promotion, while others have cleared the entire common area for new development. Initially, they were certainly capitalist enterprise zones but soon urban city expansion caught up and has spatially engulfed them as pockets delineated by formal town plans, which respect the irregular boundaries of these collectively owned zones. Economically fully urban, natives of these 'villages in cities' are not entitled to the social welfare their "urban" neighbours right outside the zones are enjoying. Current planning research focus has been on the ghettoizing of these villages due to rural-urban migration (Chen et al 2013); and on spatial equity and "ghost town" development in some of these villages that destroyed any residual arable land for building high rise units, which do not sell at all in a falling real estate market. What is significant is that the villagers enjoy communal property rights conferred on them by the state in relation to the collectives to which they belonged. The large number of these villages with great variations in environmental and economic performance provide researchers ample "urban laboratory" tests on the effects of differences in governance, controlling property rights; and/or the effects of differences in the degree of exclusive property rights controlling governance. 
The gestation of Hong Kong's container port as a new form of urban place was protracted, a very fiscally conservative government policy having decided that any such facility should not be created by way of public infrastructure investment. But once the decision was made, private property rights by way of private treaty grant of leasehold interests were created for a waterfront land use not known before.

In the context of the times, containerization was just one of a number of unitized cargo carrying solutions in play, and one that was not likely to realize a revolution unless four things happened. ${ }^{28}$ One was that the containers in question became standardized so that they would fit on any suitably built ship. The second was that other transport modes - road and rail - had suitably designed vehicles to move the containers to and from ports and the hinterland. And finally and most important, that ports and other road and rail infrastructure were re-designed and reorganized to accommodate the new form of carriage.

The last was to be a hugely expensive business in four ways, all with specific spatial implications for Hong Kong. In terms of urban planning, approach roads, container parks and handling systems needed very large amounts of flat space, which in Hong Kong was always in short supply, especially given rival demands for public housing, roads and industry. In terms of port works containerized cargo handling was illsuited to existing cargo handling cranes and systems, especially Hong

\footnotetext{
28 Other contemporary offerings were LASH, Seabee, BACAT, RoRo, LUF and pallet carrier systems see I. L. Buxton, R. P. Daggitt, J. King, Cargo Access Equipment for Merchant Ships, London: E \& F.N. Spon, 1978, Ch.2 and Stephen E. Donlon, Comparative costs of competitive shipping, Theses and Major Papers. Paper 67, pp.3-12, Part of the Oceanography and Atmospheric Sciences and Meteorology Commons, University of Rhode Island at http://digitalcommons.uri.edu/ma etds, accessed on $21^{\text {st }}$ August 2015.
} 
Progress in Planning

Kong's main strength, its large harbour with its many buoys and wellorganized mid-stream operations. In terms of naval architecture, containers were extremely unsuited to the standard designs of Hong Kong's cargo carrying mainstay, the extant world fleet of break-bulk general cargo vessels. And for Hong Kong's terrestrial infrastructure, generations of urban development with a tight grid of narrow streets and, more recently, an upwards development of the famous flatted factories, combined with the small scale of the vast majority of Hong Kong factories meant that the entire distribution system implicit in containers needed Hong Kong to undergo a radical spatial overhaul.

Inevitably the result as far as creating a container port was concerned was a gradual process, especially for Hong Kong, which has never been a pioneer in anything. Hong Kong's business world has always modeled itself on the 'second mouse at the mouse trap' principle, since the first mouse risks a lot and often with fatal results, whilst the second mouse usually gets the cheese. Hong Kong's shipping world was no different. The government worked on a parallel public policy principle, which entailed never leading but always following and, in general, leaving it to private business to invest in infrastructure development that was understood primarily to serve private business. The newspaper coverage in Hong Kong during the 1960s makes it very clear that the majority of decision makers were sat firmly on the fence as far as containerization was concerned, portentously claiming, to show simultaneously how forward looking and how wise they were, "Yes, but..." ${ }^{29}$

\footnotetext{
${ }^{29}$ A representative sample of equivocations would be South China Morning Post \& Hongkong Telegraph, Editorial, $5^{\text {th }}$ May 1966, p.12; a counsel of caution from Hong Kong's banks, $24^{\text {th }}$ September 1966, p. 26; the Director of Marine pointing out both downsides and upsides, $19^{\text {th }}$ December 1966, p.6; hesitation over commitment by Hong Kong shipowners, $10^{\text {th }}$ June 1967 , p.26 and 22 ${ }^{\text {nd }}$ June 1967, p.12; HMG Forsgate, General Manager of the Wharf Company, on problems, $26^{\text {th }}$ October 1967, p.26 - similar doubts continued to be expressed right through until beyond 1972, when the container port at Kwai Chung opened, see, for example, $1^{\text {st }}$ March 1972,
} 
By the mid-1960s arguments in favour of shifting shipping to containers began to appear in the Hong Kong press, though most often with respects to ports and shipment patterns elsewhere. However, by 1966 the clamour had become loud enough and the awareness of the potential of the change that beckoned wide enough spread that Government had formed a Container Committee to look into the matter and make recommendations. ${ }^{30}$

The Committee was thorough and, for a government committee, swift, having been formed in July 1966 and presenting its report to the Governor in December. The key recommendation was that work should begin by mid- 1967 to create a brand new container port in the Kwai Chung area - to be reclaimed from the sea as a new zone. Government took until October 1968 before it decided it needed to revisit the issues, and so commissioned a feasibility study that was expected to take eight months to complete. This produced proposals in favour of a development for tabling at the Legislative Council in August 1969, but only after the lease terms for the new facility were made public. ${ }^{31}$

Even then government was unsure. Although the preference was for a satisfactorily fiscally conservative development path, the initial announcement of the tender process allowed two possibilities because the process was covered by two separate ordinances each of which seemed only to allow one path forward. Under the Public

p.24, where the Norwegian Journal of Commerce and Shipping is quoted as pondering the possibility that containerization might prove "a gigantic failure" .

${ }^{30}$ Analysis of South China Morning Post \& Hong Kong Telegraph online database at ProQuest accessed via University of Hong Kong Libraries, 20 th August 2015 shows discussion lifting off in 1968 and growing rapidly to peak in 1972 thereafter dropping back swiftly to pre-1966 patterns.

31 "Views on Container Terminal Project", South China Morning Post \& the Hongkong Telegraph. Oct 10, 1969, p.1 
Progress in Planning

Reclamations and Works Ordinance the Government would reclaim and form the designated area, and then tenderers would be invited for developing the facility. Under the second, the Foreshores and Seabed Ordinance, the entire project - reclamation, formation and development - would be tendered. ${ }^{32}$ Finally, in February 1970 the government offered seabed leases at Kwai Chung to private sector firms or consortia interested in creating the first terminals. ${ }^{33} \mathrm{~A}$ project of four berths on a total site area of 50.6 hectares was tendered under the two possible schemes under the two ordinances. Interestingly, the first Outline Zoning Plan that covered the port came into existence only well after the private treaty grants were made to the operators. ${ }^{34}$

The successful tenderers for three of the berths - all exclusively on the reclaim, form and develop pattern - were announced on $17^{\text {th }}$ August 1970, the fourth tenderer having dropped out. ${ }^{35}$ The tender premium was to be paid in twenty annual instalments.

In the last quarter of 1970 at the far north-western edges of Victoria Harbour, just outside the official harbour limits, the first steps were taken to reclaim the massive area of foreshore and seabed. ${ }^{36}$ The first berths of the new facility opened on $27^{\text {th }}$ June 1972 . Figure 10 indicates conceptually rights conferment of this kind. Reclamation

\footnotetext{
32 "New Stage In Container Terminal Development", South China Morning Post \& the Hongkong Telegraph. Feb 14, 1970, p. 20

33 "Foreshores And Sea Bed Ordinance", South China Morning Post \& the Hongkong Telegraph. Feb 14, 1970, p. 11

${ }^{34}$ Plan No. LTW/132 dated 26 November 1971.

35 "Three firms given berths at new container terminal", South China Morning Post \& the Hongkong Telegraph. Aug 18, 1970, p.23

${ }^{36}$ For the letting of the tenders to construct the terminal to Modern Terminals Ltd, Kowloon Container Warehouse Co. Ltd., and Sea-Land Orient Ltd., see South China Morning Post \& Hongkong Telegraph, $18^{\text {th }}$ August 1970, p.23
} 
Progress in Planning

of the sea requires fill materials and these are often extracted in places where building platforms can be formed in tandem.

\section{Figure 10 about here}

Caption for Figure 10: Rights Conferring Zoning

By zoning the area of seabed and shoreline in Kwai Chung as exclusively for the development of a container port and leasing that whole area to a private consortium to develop and then operate the facility, the container port zoning conferred rights. In the years since then the original four berths and one terminal covering 50.6 hectares have increased on a similar development basis through reclamation to twenty-four berths providing 6.59 linear kilometres of wharf front in nine terminals over an area of 2.17 square kilometres. In terms of TEU throughput, this container port ranked first in the world by 1997 (Port International 2001).

\section{Scenario 7: Co-development zoning}

Also called "joint development zoning", this is the state zoning a place over which jurisdiction is disputed, for competitors or claimants to share in its development on an equal basis. This is likely the starting point for a win-win solution if competitors appreciate it as sincere and genuine. As such, the outcome is likely sustainable.

Antarctica is a good example of co-development for scientific research that excludes military and extractive use of the place under the Antarctic Treaty of 1959. International law scholar like Terr (1973) and Valencia (1986) proposed a joint development zone to overcome the disputes over the Spratly Islands. This idea was followed by Mito (1997) and Zou (2006). An attempt to put the idea into practice was made by Australia and Indonesia for the Timor Gap (Wilheim 1989). 
Progress in Planning

Another case is the joint development zone between Nigeria and Sao Tome (Groves 2005).

The very idea of the need for and probable success of codevelopment zoning we would argue to have been implicit in, if perhaps not a primary intention of the principles of the United Nations Convention on the Law of the Sea III (UNCLOS III, United Nations, 1982). This complex and elegant solution to inevitable boundary disputes once technical advances and economic growth enhanced the ability of states to project their jurisdictional power further out to sea, increased levels of pollution and environmental damage, and expanded the possibilities of economic exploitation of the sea and the seabed, has known some significant successes where, as is not the case in the South China Sea, the various parties have all concurred both with the boundaries thereby established and with the fundamental approach and spirit of the system UNCLOS III inheres.

We have mentioned a signal achievement in resolving a potential dispute over natural gas resources in the Timor Gap between Australia and Timor. This was exactly an application of the UNCLOS III rules. A more complex case is that of the North Sea.

Let us first briefly adumbrate the rules that were intended to be applied to decide sea boundaries. The key principles were and are simple, albeit resting on the actual historical experience, understandings and laws of Western Europe.

The starting point was a presumed absolute right of any state to sovereignty over its near waters. For historical and technical reasons this had been agreed to be a distance of three nautical miles. Beyond that was the domain of what were called the 'high seas' that, again for historical reasons, had come to be agreed as common to all and 
Progress in Planning

over no part of which, at least in principle, any state exercised any sovereign authority.

The narrative need not detain us, but by the 1950s, in the post-war, decolonizing context of the epoch, and with the advance of technologies for exploiting the natural resources of sea and seabed, the initial European solution, already a matter of dispute for the best part of half a century, was widely held inadequate. Starting with the first convention in 1956, with its four subsidiary agreements in 1962, 1964 (2) and 1966, and the inconclusive UNCLOS II of 1960, from 1973-1982 160 states participated in agreeing UNCLOS III, which came into force on 16 November 1994.

The key principles agreed were that every littoral state has a geodetically fixed territorial sea baseline from which all other boundaries are determined. This baseline was the boundary between 'internal waters' over which a state had absolute and unconditional sovereignty. To seaward of it extending twelve nautical miles offshore was a state's 'territorial waters' over which it had sovereignty to regulate all activity, save for the right of any vessel of any other state retaining the rights of innocent passage and refuge when in distress. ${ }^{37}$ For various reasons such a tightly defined and geographically constrained territorial sea was thought, and indeed legal argument suggests had always been thought unacceptably restrictive (Oda 1962).

To respond to this disquiet, at this point recourse was had to the key concept we are considering in this monograph, namely that of a 'zone'. What is interesting here is the implicit distinction, frequently noted above, between something with clear boundaries - like a

\footnotetext{
37 Innocent passage excludes any resource use (like fishing), any polluting (like bilge water discharge), the use of weapons in any manner, spying, or any police or warlike activity such as, for example, 'hot pursuit'.
} 
Progress in Planning

'parcel', 'lot', or 'territorial sea' - and something that has a regulatory purpose but that is in some sense not so precise, though the nature of the imprecision seems often to be left usefully vague.

To solve the insufficiencies of territorial sea boundaries - initially largely over environmental (resource protection) and fiscal (antismuggling) concerns - the concept of a 'zone' was turned to. One analysis of why argued that what a zone offered that a territorial sea did not was "legal gradation rather than confrontation" (Extavour 1979, p.31 quoting Scelle 1943). In short, an area over which supervision could be exercised and rules set, though the question of effective enforcement remained and remains problematic (Oxman 2006). Thus was introduced the 'contiguous zone', an additional extent of sea extending a further twelve nautical miles beyond the boundary of the territorial sea over which the possessing state has sovereign authority in respect of the supervision of conformity with its laws with respect customs and excise, taxation, immigration and pollution.

The issues that had in many ways occasioned the reconceptualization of sea areas, extending the authority of states further out to sea than had been the case since the days of the 'closed seas' (mares clausae) of the $16^{\text {th }}$ century, were three. A concern about the effective enforcement of national laws on taxation and excise and an increasing awareness of humanity's impact on the natural environment as a result of over-fishing and pollution that we have noted. The third, something of a latecomer, was an equally sharp awareness of the economic potential not just of seas close to state coasts, but the sea as whole. These potentials were the result on the one hand of improved fishing technologies like SONAR aided shoal location, factory ships, artificial fibre nets of enormous strength, etc., and on the other of the development of technologies allowing 
Progress in Planning

exploitation of sub-seabed resources such as petroleum and natural gas.

As a result of these advances there was clear concern, especially in the latter case, that with pre-UNCLOS rules, the more technically advanced and richer developed world would be able to exploit the high seas commons unchecked, leading inevitably not merely to the further disadvantage of latecomers, but a real risk of a 'tragedy of the commons'. As Oxman notes, the inevitable result was a further concession to the 'territorial temptation' (Oxman 2006) and, from the perspective of this monograph, a further recourse to the useful concept of a 'zone'.

There was no appetite for a return to the mares clausae of the past, with the inevitable and adverse consequences for freedom of navigation and therefore of trade. So some other solution for the seas beyond states' territorial seas and contiguous zones was needed. The way this was resolved in UNCLOS III was by the establishment of the Exclusive Economic Zone (EEZ) that extended for 200 nautical miles from a territorial sea baseline or, though each case must be internationally agreed, to the edge of the continental shelf where that is greater than 200 nautical miles.

We have argued throughout this monograph that whatever the 'fuzziness' of the concept of a 'zone' as opposed to the tight, Euclidean concept of a (territorial or property) boundary, it nonetheless necessarily rests on exactly the same survey data. Even a penumbra has a location - a locus of points, let us say, that represent the middle of the penumbral domain of uncertainty. It should therefore be of no surprise to discover the surveying consequences of UNCLOS III and its territorial sea baseline, territorial seas, contiguous zones and EEZs. As Hodgson and Smith noted when such a system was first mooted: 
"Approximately three hundred-thirty-one maritime boundaries will be required by universal claims to 200-mile zones. The United States alone will have to negotiate more than 10 percent of these maritime boundaries. Of the threehundred-thirty-one, fourteen would apply only to the territorial seas of states, that is, all intervening waters that are less than twenty-four nautical miles in breadth. The remaining three-hundred-seventeen boundaries involve, in whole or in part, extended jurisdiction to 200 miles." (Hodgson and Smith 1979, p.426),

We can now return to the North Sea and some very simple data. The North Sea is $900 \mathrm{~km}(486 \mathrm{~nm})$ long and $580 \mathrm{~km}(313 \mathrm{~nm})$ wide. It is surrounded by the land masses and islands of seven littoral states: Norway, Denmark, Germany, the Netherlands, Belgium, France and the United Kingdom. Given the basic rules of UNCLOS III, the size of the North Sea, the fact that it is rich in natural resources, both biological and mineral, and the ubiquity of Oxman's 'territorial temptation', one might expect endless disputation.

This did not happen, save in a few relatively minor cases (Friedman 1970, Grisel 1970, Klein 2004, p.257, Young, 1965), arguably much facilitated by the existence of the European Union. Instead the EEZ issues in the North Sea were treated as if the whole sea were a codevelopment zone. The junctions of all the EEZs were agreed in terms of the principles of UNCLOS III. Indeed the last remaining dispute was only resolved in 2014. It was a minor one between the Netherlands and Germany, but is an example within an example of a codevelopment zone occasioned by the growth of yet another use of offshore areas in an era of sustainable energy sources, offshore wind farms.

The problem started in 2010 when the German company EWE announced their intended construction of the $€ 450$ million Riffgat offshore wind farm. This involved thirty giant wind turbines spread over a sea area that Germany had concluded was entirely within its EEZ. However, there were unresolved issues with respect to the 
Progress in Planning

conjunction of national borders and territorial sea baselines of the Netherlands and Germany, the latter being functions of the Dutch offshore island of Schiermonnikoog and the German offshore island of Borkum.

The disputes arose over the exact course of the River Ems, which forms the Netherlands/Germany border, an issue that had been a running problem since the 1960 s. On the German interpretation of the river's course the windfarm was entirely in German waters. On the Dutch interpretation $40 \%$ of it lay in Netherlands' waters (Durr, 2012). The dispute was resolved in 2014 in a remarkable example of zoning, in this case with Germany and the Netherlands agreeing that "the border will remain ambiguous and that both countries will be responsible for the area." In fact this was an extension to seaward and final confirmation of a co-development approach to the Ems-Dollart estuary that had informed joint agreements on water management and nature conservation in internal waters, though never entirely trouble free, since the early 1960s. The German Foreign Minister Frank-Walter Steinmeier said the agreement was "a good result for the economy, for new wind farms and maritime interests." (IBRU 2014, Van der Welde in Brunet-Jailly 2015, vol.2, pp. 620-628).

It is clear co-development zoning is a viable solution to seemingly intractable EEZ problems when the 'territorial temptation' bites. However, it is also clear that any such solution depends both on good neighbourly relations and an acceptance that no one side's claims can expect to ride roughshod over the claims of others. The default is the abandonment of grandiose claims based on highly suspect, indeed often spurious ancient history and the acceptance of the allocation of zones by UNCLOS III. This leaves only the relatively minor, small area tussles of the kind exemplified in the North Sea examples standing in need of resolution. The reasonable, co-development orientated acceptance implicit in the first allocation then stands as the starting 
Progress in Planning

point for resolving the issues remaining. Figure $\mathbf{1 1}$ is the concept of co-development zoning.

\section{Figure 11 about here}

Caption for Figure 11: Co-development Zone

\section{Part 6: Discussion and conclusion}

The symphony of libertarian ideas like evolutionary planning and spontaneous planning cannot be performed in the absence of a stage laid on the foundation of the existence of real property, which has specific boundaries defining places. The discussion herein shows that the state, in defining places for whatever ad hoc, contingent or teleological reason, inevitably involves these private places.

Our inquiry into the meaning of zoning began with an explanation as to why private property as places may be understood as primeval zones: the centres of domestic and economic activities. Modern planning generally imposes by legislation new zones onto these private zones or lots, in an attempt to address environmental and other issues. Such issues are typically cross boundary, affect third parties and are understood to be incapable of avoidance by restrictive covenants. This is the setting for raising a theoretically interesting question, informed by the Coase Theorem, of whether zoning by contract is a viable alternative to zoning imposed by law. Could it be put into practice on a large geographical scale for a modern urban settlement?

The metaphor we have in mind is the contrast between traffic flows at an intersection when the traffic lights are working and when they have broken down. In both cases the traffic continues flowing. But it may be an open question as to which state of affairs is the more cost 
Progress in Planning

efficient for each vehicle taken as a single decision unit and as to which is the more efficient and effective response to traffic flow efficiency as a whole.

In our inquiry, the focus is on the neglected boundary nature of zoning. There is no direct equation implied between zoning at the lot or district and any higher jurisdictional level except purely at the level of understanding the idea of a boundary. All modern terrestrially demarcated areas have boundaries and the demarcations all depend upon a common vocabulary and battery of techniques and instrumentation to establish them. In that sense and in that sense only how planning zones are defined and established is the same as how the boundaries of states are defined and established. In a sense, given those commonalties, it is precisely the fact that any equation of higher level administrative boundaries and local/municipal zoning is neither obvious nor indisputable that is interesting. The logical grammar of a 'boundary' straddles terrestrially mappable entities that are conceptually distinct.

With that thought in mind, we turn to noting, in relation to zoning, that it cannot avoid the reality that private planning involves no less reference to property boundary lines than does public planning to zone boundaries, as in the Coase story of a land use conflict between a cattle rancher and a wheat farmer. Mapping of initial property boundaries is unavoidable in any such theoretical discussion. To explore our road junction and traffic lights metaphor, the edges of the roads, the lane dividers and the intersection layout are givens.

Our inquiry focusses on Coase's 1960 paper as it has a particular spatial application, though the fact of boundary delimitation as a feature of zoning can stand on its own as a proposition. A couple of important questions informed by Coase's theory of the firm (Coase 1937) as an institutional mechanism for coordinating transactions 
Progress in Planning

should be answered. First, is it possible to have an organized society/economy without zoning? Second, is it possible to have "public urban planning" without zoning? ${ }^{38}$ The answers to both questions are provided generally in our proposition that zoning, clear or ambiguous, is a character of private property rights in land. A more general formulation is that zoning is a spatial character of all regimes of exclusive property rights.

As for the first question, we can assume we are not dealing with the radical libertarian's atomistic world coordinated only by the "market". Equally we must assume we are not considering an autarkic world. Nor is there any assumption of an absence of spatial specialization. It follows therefore that any organized society/economy, whether of a congeries of private properties (each owned by one citizen or legal person) or centrally state-planned (a collectively owned economy) certainly involves zoning. Where the former might come to exhibit a zoning variant of what Hayek (1976, vol. 2, pp. 108-9) called 'spontaneous order', the latter he likened to a whole society as a single firm in which coordination is by means of Coasian directions to various state enterprises as production units and communes (Hayek, 1944). The latter's units (subsidiaries) have zones as they occupy land under their jurisdiction. The former's properties achieve zoning as an outcome of private treaty (planning by restrictive covenants).

As regards the second question, granted that zoning is part and parcel of exclusive property rights in land, if not also always the consequent of spatial specialization of land uses, public urban planning without zoning is impossible by definition. The scholars favouring zoning liberalization do not dispute zoning per se (leave alone destruction of the lot system) but advocate greater freedom

${ }^{38}$ We owe these two questions to a reviewer. 
Progress in Planning

for private arrangements in zoning. As intimated in the preamble and the subsequent analysis, this arrangement (such as that practised in Houston) is, as sketched above, actually one of private rezoning, i.e., rearrangement of private property rights as those were initially allocated as "lots" to private bodies according to the first layout (the first zoning plan) as upon colonization or as emerged, in whatever way it did, from a long process of historical development.

It should be noted that zoning not merely entails the existence of boundary delineations but involves boundary delineation connected with differentiated obligations and requirements for different exclusive areas introduced by the state by edict or by contract. As pointed out by a reviewer, some scholars (Siegan 1970) suggest that this planning by mutual consent without any particular specifications is not only possible, but also desirable. Others, notably Holcombe (2013) and Moroni (2012) (29 $^{39}$ suggest that it is both possible and also desirable to have only a form of (public) "self-regarding zoning" (concerning only public land) but not a form of "other-regarding zoning" (concerning private land)(Portugali 2012). Boundary delineation is not the same as fully describing zoning, but zoning necessarily involves boundary delineation as its indelible birthmark.

In this connection in this monograph we have also highlighted the hitherto ignored historical dimension in planning studies, not least the substantial contribution of the surveyor, often a military officer, to the layout and planning of European colonies. They were instrumental in land grants to attract settlers to "new land". In the process the territories of indigenous populations, often categorized as terrae nullius, were often deemed common land and hence could be appropriated at will by enclosure as "property".

${ }^{39}$ In Alexander et al (2012). 
Progress in Planning

\section{Table 2 about here}

Caption for Table 2: Zoning Scenarios and Policy Suggestions

History has as a result witnessed a complicated process of displacement of indigenous habitats. Allocated and surveyed private lots have often pushed them aside as forgotten zones. Such forgotten zones, as new property, thereby constituted the physical platform for more efficient development by private enterprise, subject first to a phase of surrender and re-grant in negotiation with the state. Eventually these developments in their turn become subject to zoning by legislation to cope with issues affecting third parties. Yet the question remains: might such issues, intelligible in terms of Coasian transaction cost reasoning, be also resolvable by Coasian solutions as propounded by libertarian thinkers? The answer is beyond the remit of this monograph. Nevertheless, some recommendations based on the concern for reducing transaction costs are listed in Table 2. Growth in value of land and advancement in surveying technology push up demand for "accurately delineated" property and other forms of zone boundaries. However, what constitutes "clearly defined" boundaries in specific situations remains a high transaction cost question that will continue to benefit lawyers, planners and surveyors because what constitutes "clarity" is affected by values and interests, leading to contests and disputes. This is one of the shades in the penumbra we mention in this monograph.

Hopefully, this monograph will awaken an interest of the student of planning to the existence and nature of the tension between accuracy and clarity/penumbrality in zone boundaries. The student must be cautioned that a Coasian discussion about exchange of rights has an implicit "transactionist" presumption that the domain for private negotiation or unilateral grants is of a given area and hence any trade is about the re-partitioning of the domain between parties. 
Progress in Planning

Any conceptualization that involves the possibility and mode of an area expansion of the Coasian domain, depicted in Figure 12, is something for further thinking.

Figure 12 about here

Caption for Figure 12: Expansion of Coasian Negotiable Domain

\section{Acknowledgements}

The authors are grateful to chartered land surveyor Dr. Ken S.T. Ching for his help in producing Figure 3 and Mr. Mark Hansley Chua for preparing Figures 2 and 4 to 12. They are also in debted to two anonymous referees of Progress in Planning for their useful comments and advice.

\section{Part 7: Bibliography}

Abercrombie, P. (1933), Town and Country Planning. London: Oxford University Press.

Acheson, J. M. (2015), "Private Land and Common Oceans: Analysis of the Development of Property Regimes," Current Anthropology, Vol. 56, No. 1, pp.28-55

Alexander, E.R. (1992), Approaches to Planning: Introducing Current Planning Theories, Concepts and Issues. Yverdon: Gordon and Beach Science.

Alexander, E.R., Mazza, L. and Moroni, S. (2012 eds), "Planning without Plans? Nomocracy or Teleocracy for Social-Spatial Ordering," Progress in Planning, Vol. 77, No.2. pp. 46-59.

Alfasi N. and Portugali, J. (2007), "Planning Rules for a Self-Planned City," Planning Theory, Vol. 6, No. 2, pp. 164-182. 
Progress in Planning

Allen, D. W. (1991), "Homesteading and Property Rights or 'How the West was Really Won?" " Journal of Law and Economics 34, No.1, pp.1-23.

Alterman, Rachelle (2011 eds.) Takings International: a Comparative Perspective on Land use Regulations and Compensation Rights. Chicago: American Bar Association.

Andersson, David Emanuel and Stefano Moroni (2014 eds.), Cities and Private Planning Property Rights, Entrepreneurship and Transaction Costs, Edward Elgar: Cheltenham.

Bassett, E.M. (1924), "Constitutionality of Zoning in the Light of Recent Court Decision", National Municipal Review, Vol.13, No.9, pp.492-497.

Berkowitz, A. (1994), "The Law and the Land: Why Biblical Israel has Artificial Territorial Boundaries." Tradition, Vol. 28, No. 2, pp. 34-43.

Bellwood, P. S. (2004), First Farmers: The Origins of Agricultural Societies. Malden, MA: Wiley-Blackwell.

Beuscher, J.H. (1958), "Private Zoning on Milwaukee's Metropolitan Fringe - A Preface," Wisconsin Law Review, Vol.1958, pp.610-611.

Borgan, B.E. (1956-57), "Jurisdiction of Zoning Boards," Kentucky Law Journal, Vol.45, pp.507-517.

Borges, J.L., (trans. de Giovanni, N.T.) (1975), "On the Exactitude of Science," in A Universal History of Infamy, London: Penguin Books.

Brunet-Jailly, E. (ed.) (2015), Border Disputes: a Global Encyclopaedia, 3 vols, Santa Barbara (CA): ABC Clio. 
Progress in Planning

Buchanan, J.M. (1991), Property as a Guarantor of Liberty. Aldershot: Edward Elgar.

Burke, G. and Taylor, T. (1990), Town Planning and the Surveyor. Whiteknights: College of Estate Management.

Cappel, A.J. (1991), “A Walk along Willow: Patterns of Land Use Coordination in Pre-Zoning New Haven (1870-1926)," The Yale Law Journal, Vol.101, No.3, pp.617-642.

Cartwright, D.E. and Melchior, P. (2001), Tides: a Scientific History. Cambridge: Cambridge University Press.

Chen, H., Chan, R. C. K. and He, Q. (2013), "From Excluded Ghettos to Exclusionary Enclaves: A Private Sector Initiative in Guangzhou, China," LHI Journal, Vol. 4, No.3:pp. 211-223.

Cherry, G.E. (1996), Town and Country Planning in Britain since 1990. Oxford: Blackwell.

City of Brentwood, Mo., "What is Zoning All About?" http://www.brentwoodmo.org/index.asp?ID=I I (last visited Dec. 18, 2013).

Clapp, James A. "Shylock Ghetto: The Place of the Play." Places, 2, No.3 (1986): pp. 40-46.

Coase, R.H. (1937), "The Nature of the Firm," Economica, n.s., Vol.4, pp. 386-405.

Coase, R.H. (1959), "The Federal Communications Commission," Journal of Law and Economics, Vol.2, pp.1-40. 
Progress in Planning

Coase, R.H. (1960), "The Problem of Social Cost," Journal of Law and Economics, Vol.3, pp.1-44.

Consigny, R.H. and Zile, Z.L. (1958), "Part I: Use of Restrictive Covenants in a Rapidly Urbanizing Area," Wisconsin Law Review, Vol.1959, pp.612-640.

Costonis, J. C. (1973), "Development Rights Transfer: An Exploratory Essay," Yale Law Journal, Vol. 83, pp. 75-85.

Costonis, J.C. (1975), "'Fair" Compensation and the Accommodation Power: Antidotes for the Taking Impasse in Land Use Controversies," Columbia Law Review, Vol. 75. No.6. pp. 1021-1082

Crowell, C.E. (1931), "Judicious Liberty," The North American Review, Vol.232, No.4, pp.320-327.

de Klemm, C. and C. Shine. (1993), Biological Diversity Conservation and the Law. IUCN, Gland, Switzerland and Cambridge, U.K, 292 pp.

Demsetz, H. (1967), "Toward a Theory of Property Rights", The American Economic Review, Vol. 57, No. 2, Papers and Proceedings of the Seventy-ninth, Annual Meeting of the American Economic Association. pp. 347-359.

Deng, F. (2003), "The Rebound of Private Zoning: Property Rights and Local Governance in Urban Land Use," Environment and Planning A, Vol. 35, pp. 133-149.

Doodson, A. T. (1921), "The Harmonic Development of the TideGenerating Potential," Proceedings of the Royal Society of London. 
Progress in Planning

Series A, Containing Papers of a Mathematical and Physical Character, pp. 305-329.

Durr, B. (2012), "Wind Park in No Man's Land: Offshore Project Stirs up German-Dutch Border Dispute," Der Spiegel Online at http://www.spiegel.de/international/europe/ewe-wind-park-riffgatcaught-up-in-german-dutch-border-dispute-a-843419.html accessed on 28.1.2016

Edwards, N. (1992), "The Colonial Suburb: Public Space as Private Space," Ch.3 in Chua Beng Huat \& Norman Edwards (eds), Public Space: Design Use and Management, Singapore: University of Singapore Press.

Epstein, R. A. (1996). "A Conceptual Approach to Zoning: What's Wrong with Euclid," New York University Environmental Law Journal, Vol. 5, pp 277-291.

Extavour, W.C. (1979), The Exclusive Economic Zone: a study of the evolution and progressive development of the International Law of the Sea, Geneva: Institut universitaire de hautes études internationales.

Fischel, W.A. (1985), The Economics of Zoning Laws: a Property Rights Approach to American Land Use Controls. Baltimore: John Hopkins University Press.

Fischel, W.A. (1995), Regulatory Takings: Law, Economics and Politics. Cambridge, M.A.: Harvard University Press.

Fischer, E. (1949), "On Boundaries," World Politics, Vol. 1, No. 2, pp. 196-222 
Progress in Planning

Fitzpatrick, R. (ed) (2009), Euclid's Elements of Geometry, e-book at http://farside.ph.utexas.edu/Books/Euclid/Elements.pdf accessed on 1.7.2016.

Fleischman, F., Ban, N., Evans, L., Epstein, G., Garcia-Lopez, G., \& Villamayor-Tomas, S. (2014), "Governing Large-scale Social-ecological Systems: Lessons from Five Cases," International Journal of the Commons, Vol. 8, No. 2, pp. 428-456.

Foy, K.C. (2012), "Home is Where the Health is: the Convergence of Environmental Justice, Affordable Housing and Green Building," Pace Environmental Law Review, Vol.30, No.1, pp.1-57.

Friedmann, W. (1970), "North Sea Continental Shelf Cases: A Critique," American Journal of International Law, Vol.64, p. 229-240.

George, S. (2000), Liverpool Park Estates: Their Legal Basis, Creation and Early Management, Liverpool: Liverpool University Press.

Glasze, Georg, Chris Webster, and Klaus Frantz. Private Cities: Global and Local Perspectives. Oxon: Routledge, 2004.

Gordon, P. and Richardson, H.W. (2001), "The Sprawl Debate: Let Markets Plan," The Journal of Federalism, Vol.31, No.3, pp.131-149.

Government of Hong Kong (1931), A Memorandum on the Law of Foreshore and Seabed with Relation to the Colony of Hong Kong, Hong Kong: Noronha.

Great Barrier Reef Marine Park Authority (1982), "Basis of Zoning, Cairn and Cormorant Pass Sections."

Grisel, E. (1970), "Lateral Boundaries of the Continental Shelf and the Judgment of the International Court of Justice in the North Sea 
Progress in Planning

Continental Shelf Cases," American Journal of International Law, vol. 64 p. 562

Groves, H. (2005), "Offshore Oil and Gas Resources: Economics, Politics and the Rule of Law in the Nigeria-Sao Tome e Principe Joint Development Zone," Journal of International Affairs, Vol. 59, No. 1, pp. 81-96.

Hall, P. (1999), Cities of Tomorrow: Updated. Oxford: Blackwell.

Hall County Board of Commissioners (2009), "Planning and Zoning".

Hassan, A. S. (2009). "The British Colonial 'Divide and Rule' Concept: its Influence to Transport Access in Inner City of George Town, Penang," Transportation, Vol. 36, No. 3, pp. 309-324.

Hayek, F.A. (1944), The Road to Serfdom. Chicago: University of Chicago Press.

Hayek, F. A. (1960), The Constitution of Liberty. Chicago: University of Chicago Press.

Hayek, F.A. (1976), Law, Legislation, and Liberty, vol.2, The Mirage of Social Justice, Chicago: University of Chicago Press.

Heikklia, E.J. (2000), The Economics of Zoning, Rutgers: Centre for Urban Policy Research.

Hewitt, R. (2011), Map of a Nation: a Biography of the Ordnance Survey. Croydon: Granta Books.

Hirt, S. (2012), “Mixed Use by Default: How the Europeans (Don't) Zone," Journal of Planning Literature, Vol.27, No.4, pp.375-393. 
Hodgson, R.D. and Smith R.W. (1979), "Boundary Issues Created by Extended National Marine Jurisdiction", Geographical Review, Vol. 69, No. 4, pp. 423-433

Holcombe, R.G. (2013), "Planning and the Invisible Hand: Allies or Adversaries?" Planning Theory, Vol. 12, No.2. pp. 199-210.

Hole, F. (1984), "A Reassessment of the Neolithic Revolution," Paléorient, Vol. 10, No. 2. pp. 49-60.

Home, R. (1997), Of Planting and Planning: The Making of British Colonial Histories, London: Spon.

IBRU: Centre for Borders Research (2014), "Germany and the Netherlands end Ems River border dispute", at https://www.dur.ac.uk/ibru/news/boundary news/?itemno $=22677$ \&rehref=\%2Fibru\%2Fnews\%2F\&resubj=Boundary+news+Headlines accessed on $28^{\text {th }}$ January 2016.

Innes, R. (1997). "Takings, Compensation, and Equal Treatment for Owners of Developed and Undeveloped Property," Journal of Law and Economics, Vol. 40, No. 2, pp. 403-432.

Jarzombek, M. (2010), "Corridor Spaces", Critical Inquiry, Vol. 36, pp.728-770.

Jones, B. (1990), Neighbourhood Planning: A Guide for Citizens and Planners. Chicago: American Planning Association.

Johnson, C. (1974), "Missouri-French Houses: Some Relict Features of Early Settlement." Pioneer America, pp. 1-11. 
Progress in Planning

Klein, N. (2004), Dispute settlement in the UN Convention on the Law of the Sea, Cambridge: Cambridge University Press.

Ko, W.W.H. (2009), "Land Use Segregation and Mixing through Zoning Controls in Greater Sydney," Bachelor of Planning Thesis, University of New South Wales.

Lafferty, R.N. and Frech III, H.E. (1978), "Community Environment and the Market Value of Single-Family Homes: the Effect of the Dispersion of Land Uses," Journal of Law and Economics, Vol.21, pp.381-394.

Lai, L.W.C. (1994), "The Economics of Land Use Zoning - A Literature Review and Analysis of the Work of Coase," Town Planning Review, Vol. 65 No. 1, pp. 77-98.

Lai, L.W.C. (1996), Zoning and Property Rights: a Hong Kong Case Study. Hong Kong: Hong Kong University Press. 1996.

Lai, L.W.C. (1997), "The Property Rights Justifications for Planning and a Theory of Zoning," in Progress in Planning: Recent Research in Urban and Regional Planning, Vol.48, No.3 (November): pp.161-246.

Lai, L.W.C. (1998), "The Leasehold System as a Means of Planning by Contract: the Hong Kong Case," Town Planning Review, Vol.69, No.3 (1998), pp.245-271.

Lai, L.W.C. (1999), "Reflections on the Abercrombie Report 1948," Town Planning Review, Vol. 70, No. 1, pp. 61-87.

Lai, L.W.C. (2007), "'The Problem of Social Cost': the Coase Theorem and Externality Explained: Using Simple Diagrams and Examples to 
Progress in Planning

Illustrate the Role of Land Use Planning in Tackling Externalities," Town Planning Review, Vol.78, No.3, pp.335-368.

Lai, L.W.C. (2014), "As Planning is Everything, it is Good for Something!" A Coasian Economic Taxonomy of Modes of Planning," Planning Theory. DOI: 10.1177/1473095214542632

Lai, L.W.C. (2015), “'Where to Draw the Line?' That is a Land Use Planning Question for the Land Surveyor and the Town Planner," Land Use Policy, Vol. 42: pp. 619-627.

Lai, L.W.C. (2016), "Un-forgetting Walls by Lines on Maps: a Case Study on Property Rights, Cadastral Mapping, and the Landscape of the Kowloon Walled City," Land Use Policy, Vol.57, pp. 94-102.

Lai, L.W.C. and Ho, D.C.W. (2014), "Farms Are Not Zoos: a PostColonial Study on Enclosure and Conservation of Military Heritage Buildings in Hong Kong," Urban Studies, DOI: 10.1177/0042098015569967

Lai, L.W.C. and Kwong, V.W.C. (2012), "Racial Segregation by Legislative Zoning and Company Law: an Empirical Hong Kong Study," Environment and Planning B: Planning and Design, Vol. 39, No.3, pp. 416-438.

Lai, L.W.C., Chau, K.W. and Lorne, F.T. (2015), "'Unclear' Initial Delineation of Property Boundaries and the Third Coase Theorem," Land Use Policy, Vol. 47, pp.273-281.

Lai, L.W.C., Davies, S.N.S. and Lorne, F.T. (2015), “Creation of Property Rights in Planning by Contract and Edict: Beyond Coasian Bargaining in Private Planning," Planning Theory, doi:10.1177/1473095215596546. 
Progress in Planning

Lai, L.W.C., Tan, Y.K., Davies, S.N.G., and Yung, P. (2009), "The Gin Drinker's Line: Reconstruction of a British Colonial Defence Line in Hong Kong Using Aerial Photo Information," Property Management, Vol. 27, No. 1, pp.16-41.

Lai, L.W.C., Lorne, F.T., Chau, K. W. and Ching, K.S.T. (2016), "Informal Land Registration under Unclear Property Rights: Witnessing Contracts, Redevelopment, and Conferring Property Rights," Land Use Policy, Vol. 50, pp. 229-238.

Li, T. M. (2014), "What is Land? Assembling a Resource for Global Investment." Transactions of the Institute of British Geographers, Vol. 39, No. 4, pp. 589-602.

Libecap, G, D., and Lueck, D. (2011), "The Demarcation of Land and the Role of Coordinating Property Institutions," Journal of Political Economy Vol. 119, No. 3, pp. 426-467.

Libecap, G D., Lueck, D. and O'Grady, T. (2011), "Large-Scale Institutional Changes: Land Demarcation in the British Empire," " Journal of Law and Economics, Vol. 54, No. 4, pp. S295-S327.

Liebmann, G.W. (2000). Land readjustment for America: A proposal for a statute. The Urban Lawyer, pp.1-20.

Locke, J. (1959), An Essay Concerning Human Understanding. Fraser, A.C. (ed.), 2 vols, New York: Dover.

Lundberg, W. (1973), "Restrictive Covenants and Land Use Control: Private Zoning," Montana Law Review, Vol.34, pp.199-217.

Macintosh, D.J., Phillips, M.J., III, R.R.L. \& Clough, B. (2002), Annexes to the Thematic Review on Coastal Wetland Habitats and Shrimp 
Progress in Planning

Aquaculture: Case Studies 1-6, Report prepared under the World Bank, NACA, WWF and FAO Consortium Program on Shrimp Farming and the Environment. Work in Progress for Public Discussion. Published by the Consortium. 211 pages.

Mandelbrot, B (1982), The Fractal Geometry of Nature. New York: W. H. Freeman and Co.

Manning, J and Bekkering, H. (2015 eds), Mapping Detroit: land, community and shaping a city, Detroit, Michigan, Wayne State University Press.

Metzenbaum, James (1957), "The History of Zoning: A Thumbnail Sketch, The Western Reserve Law Review. Vol. 9, pp. 36-42.

Maraist, P. W. (1995). "Statutory Beacon in the Land Use Ripeness Maze: The Florida Private Property Rights Protection Act," Florida Law Review, Vol. 47, pp. 411-458.

Matjiya, A. (2009),"Assessing the Housing Policy Framework in Promoting Inclusionary Housing Developments," MSc Thesis, Department of Planning, University of the Witwatersrand.

Micelli, E. and Faggiani, A. (2001), "New Tools for Land Policy in Italy," 8th European Real Estate Society Conference, Alicante 26-29 June 2001.

Moroni, S. (2012), "Why Nomocracy: Structural Ignorance, Radical Pluralism and the Role of Relational Rules," In Alexander, E.R., Mazza, L. and Moroni, S. (2012 eds), "Planning without Plans? Nomocracy or Teleocracy for Social-Spatial Ordering," Progress in Planning, Vol. 77, No.2. pp. 46-59. 
Progress in Planning

Mundy, B., and Lane, T. (2011), "Preserving Agricultural and Forest Land: a TDR Approach," Journal of Property Investment \& Finance, Vol. 29, No. 45, pp. 566-574.

Nolan, B.J. (2003). "Metaphysics of Property: Looking beneath the Surface of Regulatory Takings Law after Tahoe-Sierra Preservation Council v. Tahoe Regional Planning Agency," St. Louis University Law Journal, Vol.48, pp.703-754.

Oxman, B.H. (2006), "The Territorial Temptation: A Siren Song at Sea," The American Journal of International Law, Vol. 100, No. 4, pp. 830851

Perin, Constance (1977), Everything in Its Place: Social Order and Land Use in America. Princeton, N.J.: Princeton University Press.

Planning Institute of Australia, "What is Zoning and Why are There Different Requirements in Different Areas?" PIA Fact Sheet 17, PIA: South Australian Division, Australia.

Portugali, J. (2012). "Complexity Theories of Cities: Implications to Urban Planning," In J. Portugali, H. Meyer, E. Stolk and E. Tan (eds.), Complexity Theories of Cities Have Come of Age. Berlin: Springer, pp. 221-224.

Price, E.T. (1995), Dividing the land: Early American Beginnings of our Private Property Mosaic. Chicago: University of Chicago Press.

Proudfoot, Helen (1996). Town Plans: Their Impact on the Settlement Process of Australia (1788 - 1849), Macquarie University, PHD Thesis.

Mito, L. A. (1997), "Timor Gap Treaty as a Model for Joint Development in the Spratly Islands," American University International Law Review, Vol. 13, pp.727 -764. 
Progress in Planning

Neuwirth, R. (2006) Shadow Cities: A Billion Squatters, a New Urban World, New York: Routledge.

Oda, S. (1962), "The Concept of the Contiguous Zone," The International and Comparative Law Quarterly, Vol. 11, No. 1 pp. 131153

Polsky, H. (1975), "Exclusionary Zoning: Will the Law Provide a Remedy," Indiana Law Review, Vol.8, pp.995-1027.

Port International 2001, "Save the Best until Last"' Vol.1, p. 43.

Punter, J. (1999). Design Guidelines in American Cities: a Review of Design Policies and Guidance in Five West Coast Cities, Liverpool: Liverpool University Press.

Renard, V. (2007). "Property Rights and the 'Transfer of Development Rights': Questions of Efficiency and Equity," Town Planning Review, Vol. 78, No. 1, pp. 41-60.

Renger, J.M. "Institutional, Communal, and Individual Ownership or Possession of Arable Land in Ancient Mesopotamia from the End of the Fourth to the End of the First Millennium B.C.", Chicago-Kent Law Review, Vol. 71.1, pp.269-319

Ross, M.M., Smith, L.J., and Pritt, R.D. (1996), "The Zoning Process: Private Land-use Controls and Gated Communities, the Impact of Private Property Rights Legislation, and Other Recent Developments in the Law," The Urban Lawyer, Vol.28, No.4, pp.801-817. 
Progress in Planning

Sayer, G. R. (1980) Hong Kong 1841-1862: Birth, Adolescence and Coming of Age, Hong Kong: Hong Kong University Press.

Scelle, G. (1943), Manuel élémentaire de droit international public, Paris: Dumat-Montchrestian.

Shepard, S.A. (2011), “Adverse Possession, Private-Zoning Waiver \& Desuetude: Abandonment and Recapture of Property and Liberty Interests," University of Michigan Journal of Legal Reform, Vol.44, No.3, pp.557-623.

Shogren, J. F., Parkhurst, G. M., \& Settle, C. (2003). “Integrating Economics and Ecology to Protect Nature on Private Lands: Models, Methods, and Mindsets," Environmental Science \& Policy, Vol. 6, No.3, pp. 233-242.

Siegan, B.H. (1970), "Non-Zoning in Houston," Journal of Law and Economics, Vol.13, No.1, pp.71-147.

Siegan, B.H. (1994), "Non-Zoning is the Best Zoning" California Western Law Review, Vol.31, pp.127-140.

Skorburg, J.W. (2008), "Ten Principles of Real Estate Markets (Student Companion)," Econ 593 - Internship Program University of Illinois at Chicago.

(https://heartland.org/sites/all/modules/custom/heartland migrati on/files/pdfs/24276.pdf).

Staley, S.R. (2001), "Ballot Box Zoning, Transaction Costs and Urban Growth," Journal of American Planning Association, Vol. 67, No. 1: pp. 25-31. 
Progress in Planning

"Stark County Rezoning Application Directions," A Zoning - Update, 2005 - starkcountynd.gov.

(http://www.starkcountynd.gov/vertical/sites/\%7B32FA3A56-B3F64B8B-A428-

F9C97B78EC24\%7D/uploads/Stark_County_Rezoning_Directions2_2013.pdf).

Statham-Drew, P. (1990), The Origins of Australia's Capital Cities, Cambridge University Press.

Statham-Drew, P. (2004), James Stirling and the Birth of the Swan river Colony. Swanbourne, Pandorous Publishing.

Stilgoe, J (1976), "Documents in Landscape History." Journal of Architectural Education, Vol. 30, No.1, pp. 15-18.

Stoddard, B.W. (1987), "Zoning as a Means of Controlling Commercial Strip Development," Master of City Planning Thesis, Department of Urban Studies and Planning, Massachusetts Institute of Technology.

Stringham, E.P., Miller, J.K., and Clark, J.R. (2010), "Internalizing Externalities through Private Zoning: The Case of Walt Disney Company's Celebration, Florida," Journal of Regional Analysis and Policy, Vol.40, No.2, pp.96-103.

Strong, A. L., Mandelker, D. R., \& Kelly, E. D. (1996), "Property Rights and Takings," Journal of the American Planning Association, Vol. 62, No. 1, pp. 5-16.

Terr, L.B. (1973), "Distance plus Joint Development Zone Formula: A Proposal for the Speedy and Practical Resolution of the East China and Yellow Seas Continental Shelf Oil Controversy," Cornell International Law Journal, Vol.7, pp.49-71. 
Progress in Planning

Thrift, N. (2003), "Space: The Fundamental Stuff of Human Geography". In Sarah L. Hollaway, Stephen P., Rice and Gill Valentine. Key Concepts in Geography. London: SAGE. pp. 95-107.

Umbeck, J. (1981). "Might Makes rights: A theory of the Formation and Initial Distribution of Property Rights," Economic Inquiry, Vol. 19, No. 1, pp. 38-59.

United Nations (1982), Final Act of the Third United Nations Conference on the Law of the Sea, at http://www.un.org/Depts/los/convention agreements/texts/final a ct eng.pdf accessed on 28th January, 2016

Urban, M. (1973), University of California Los Angeles Law Review, Vol.21, pp.1655-1689.

Valencia, M. J. (1986), "Taming Troubled Waters: Joint Development of Oil and Mineral Resources in Overlapping Claim Areas," San Diego Law Review, Vol. 23, pp. 661- 684.

Walker, P. A., and Peters, P.E. (2001), "Maps, Metaphors, and Meanings: Boundary Struggles and Village Forest Use on Private and State Land in Malawi." Society \& Natural Resources, Vol. 14, No. 5, pp. 411-424.

Weir, R. (2012), "A Note of British Blockhouses in Hong Kong," Surveying and Built Environment, Vol. 22, No. 1, pp. 8-18.

Wheeler, I, Fittipaldi, J.J., Forrest, C.W., Marlatt, R.M. (1988), "Army Master Planning: an Analysis of Policy and Procedures," US Army Corps of Engineers, Construction Engineering C Research Laboratory. 
Progress in Planning

Van der Welde, M. (2015), "Germany Netherlands: Ems-Dollart Estuary", in Brunet-Jailly (2015)

Veblen, T. (1898-99), "The Beginning of Ownership", American Journal of Sociology, Vol. 4, pp. 352-365.

Webster, C.J. and Lai, L.W.C. (2003), Property Rights, Planning and Markets: Managing Spontaneous Cities. Aldershot: Edward Elgar.

Willis, K.G. (1980), The Economics of Town and Country Planning. London, Granada.

Willheim, E. (1989), "Australia-Indonesia Sea-Bed Boundary Negotiations: Proposals for a Joint Development Zone in the Timor Gap," Natural Resources Journal, Vol. 29, pp. 821-842.

Xu, M., Yu, Z., \& Yang, X. (2015). "The Marketization of Land-related Indicators Based on the Practice in Anhui Province," Asian Agricultural Research, 7(3), p.89 - 91.

Yin, R. S., Yao, S. B., and Huo, X. X. (2013), "Deliberating How to Resolve the Major Challenges Facing China's Forest Tenure Reform and Institutional Change," International Forestry Review, Vol. 15, No. 4, pp. 534-543.

Young, R. (1965), "Offshore Claims and Problems in the North Sea," American Journal of International Law, Vol. 59, No.3, pp. 505-522.

Yu, B.T., Shaw, D, Fu, T. and Lai, L.W.C. (2000), "A Property Rights and Contractual Approach to Sustainable Development," Environmental Economics and Policy Studies, Vol. 3, No. 3, pp. 291-309. 
Progress in Planning

Zile, Z. L. (1959), "Private Zoning on Milwaukee's Metropolitan Fringe: Problems of Drafting-Part II," Wisconsin Law Review, Vol. 1959, pp. 451-488.

Zou, K.Y. (2006), "Joint Development in the South China Sea: a New Approach," The International Journal of Marine and Coastal Law, Vol. 21, No. 1, pp. 83-109.

Table 1: Zoning Scenarios and Their Transaction Cost, Informational \& Innovative Dimensions 
Progress in Planning

\begin{tabular}{|c|c|c|c|}
\hline $\begin{array}{l}\text { Zoning Scenario } \\
\text { and its Property } \\
\text { Rights Implication }\end{array}$ & Transaction Cost & $\begin{array}{l}\text { Information } \\
\text { and Innovation }\end{array}$ & $\begin{array}{l}\text { Post intervention } \\
\text { Market Outcomes }\end{array}$ \\
\hline $\begin{array}{l}\text { Conflict of zoning } \\
\text { (attenuation of } \\
\text { private property } \\
\text { rights) }\end{array}$ & $\begin{array}{l}\text { Increased } \\
\text { (for private } \\
\text { development) }\end{array}$ & $\begin{array}{l}\text { State-generated } \\
\text { information } \\
\text { confusion; } \\
\text { conducive to } \\
\text { rent-seeking } \\
\text { behaviour }\end{array}$ & $\begin{array}{l}\text { Rent-seeking } \\
\text { activities to capture } \\
\text { lost rent re } \\
\text { recapture lost rent } \\
\text { Land supply } \\
\text { restricted }\end{array}$ \\
\hline $\begin{array}{l}\text { Borderline non- } \\
\text { zoning } \\
\text { (attenuation of } \\
\text { private property } \\
\text { rights) }\end{array}$ & $\begin{array}{l}\text { Increased } \\
\text { (for private } \\
\text { development) }\end{array}$ & $\begin{array}{l}\text { State-generated } \\
\text { information } \\
\text { confusion }\end{array}$ & $\begin{array}{l}\text { Litigation and } \\
\text { disputes when } \\
\text { property values rise }\end{array}$ \\
\hline $\begin{array}{l}\text { Incomplete zoning } \\
\text { (leading to a } \\
\text { degree of common } \\
\text { property) }\end{array}$ & $\begin{array}{l}\text { Increased } \\
\text { (rent dissipation) }\end{array}$ & $\begin{array}{l}\text { State-generated } \\
\text { information } \\
\text { confusion; } \\
\text { conducive to } \\
\text { rent-seeking } \\
\text { behaviour }\end{array}$ & $\begin{array}{l}\text { Efforts by parties to } \\
\text { define rights to } \\
\text { constrain rent } \\
\text { dissipation }\end{array}$ \\
\hline $\begin{array}{l}\text { Forgotten zones } \\
\text { (leading to a } \\
\text { degree of common } \\
\text { property) }\end{array}$ & $\begin{array}{l}\text { Increased } \\
\text { (social conflicts) }\end{array}$ & $\begin{array}{l}\text { State-generated } \\
\text { misinformation; } \\
\text { conducive to } \\
\text { rent-seeking } \\
\text { behaviour }\end{array}$ & $\begin{array}{l}\text { Political } \\
\text { confrontation and } \\
\text { non-market } \\
\text { negotiations }\end{array}$ \\
\hline $\begin{array}{l}\text { Zoning for "non- } \\
\text { planning" } \\
\text { (assigning a degree } \\
\text { of de facto private } \\
\text { property) }\end{array}$ & $\begin{array}{l}\text { Reduced } \\
\text { (decreased } \\
\text { uncertainty in } \\
\text { the non- } \\
\text { planning area) }\end{array}$ & $\begin{array}{l}\text { State } \\
\text { disseminates } \\
\text { and collects } \\
\text { market } \\
\text { information; } \\
\text { conducive to } \\
\text { win-win } \\
\text { innovations }\end{array}$ & $\begin{array}{l}\text { Expansion in market } \\
\text { transactions and } \\
\text { innovations }\end{array}$ \\
\hline $\begin{array}{l}\text { Rights-conferring } \\
\text { zoning }\end{array}$ & Reduced & $\begin{array}{l}\text { State } \\
\text { disseminates } \\
\text { and collects }\end{array}$ & $\begin{array}{l}\text { Expansion in market } \\
\text { transactions and } \\
\text { innovations }\end{array}$ \\
\hline
\end{tabular}


Progress in Planning

\begin{tabular}{|c|c|c|c|}
\hline $\begin{array}{l}\text { (conferring de jure } \\
\text { communal or } \\
\text { private property) }\end{array}$ & $\begin{array}{l}\text { (less rent } \\
\text { dissipation than } \\
\text { anarchy) }\end{array}$ & $\begin{array}{l}\text { market } \\
\text { information; } \\
\text { conducive to } \\
\text { win win } \\
\text { innovations }\end{array}$ & \\
\hline $\begin{array}{l}\text { Co-development } \\
\text { zoning } \\
\text { (conferring de jure } \\
\text { private property) }\end{array}$ & $\begin{array}{l}\text { Reduced } \\
\text { (fewer conflicts } \\
\text { and rent } \\
\text { dissipation by } \\
\text { conferring rights } \\
\text { to de facto } \\
\text { competitors } \\
\text { with the state) }\end{array}$ & $\begin{array}{l}\text { State } \\
\text { disseminates } \\
\text { and collects } \\
\text { market } \\
\text { information; } \\
\text { conducive to } \\
\text { win win } \\
\text { innovations }\end{array}$ & $\begin{array}{l}\text { Expansion in market } \\
\text { transactions and } \\
\text { innovations }\end{array}$ \\
\hline
\end{tabular}


Progress in Planning

\section{Table 2: Zoning Scenarios and Policy Suggestions}

\begin{tabular}{|l|l|l|}
\hline $\begin{array}{l}\text { Zoning Scenario } \\
\text { and its Property } \\
\text { Rights Implication }\end{array}$ & Transaction Cost & $\begin{array}{l}\text { Some Policy Suggestions } \\
\text { (beyond adoption of better land } \\
\text { surveying techniques) }\end{array}$ \\
\hline $\begin{array}{l}\text { Conflict of zoning } \\
\text { (attenuation of } \\
\text { private property } \\
\text { rights) }\end{array}$ & $\begin{array}{l}\text { Increased } \\
\text { (for private } \\
\text { development) }\end{array}$ & $\begin{array}{l}\text { Mandatory requirements for planning } \\
\text { proposals to respect exiting de jure } \\
\text { property boundaries and to avoid } \\
\text { conflict of zones }\end{array}$ \\
\hline $\begin{array}{l}\text { Borderline non- } \\
\text { zoning } \\
\text { (attenuation of } \\
\text { private property } \\
\text { rights) }\end{array}$ & $\begin{array}{l}\text { (for private } \\
\text { development) }\end{array}$ & $\begin{array}{l}\text { Preference for private over public } \\
\text { zoning, subject to certain technical } \\
\text { standards, for ordinary land uses }\end{array}$ \\
\hline $\begin{array}{l}\text { Incomplete zoning } \\
\text { (leading to a } \\
\text { degree of common } \\
\text { property) }\end{array}$ & $\begin{array}{l}\text { Increased } \\
\text { (rent dissipation) }\end{array}$ & $\begin{array}{l}\text { Complete incomplete zones by public } \\
\text { at a low cost }\end{array}$ \\
\hline $\begin{array}{l}\text { Forgotten zones } \\
\text { (leading to a } \\
\text { degree of common } \\
\text { property) }\end{array}$ & $\begin{array}{l}\text { Increased } \\
\text { (social conflicts) }\end{array}$ & $\begin{array}{l}\text { rights } \\
\text { localion of transfer of development }\end{array}$ \\
\hline $\begin{array}{l}\text { Zoning for "non- } \\
\text { planning" } \\
\text { (assigning a degree } \\
\text { of de facto private } \\
\text { property) }\end{array}$ & $\begin{array}{l}\text { Reduced } \\
\text { (decreased } \\
\text { uncertainty in } \\
\text { the non- } \\
\text { planning area) }\end{array}$ & $\begin{array}{l}\text { Establish public registers for } \\
\text { transactions to lower transaction } \\
\text { costs of searching }\end{array}$ \\
\hline
\end{tabular}


Progress in Planning

\begin{tabular}{|l|l|l|}
\hline $\begin{array}{l}\text { Rights-conferring } \\
\text { zoning } \\
\text { (conferring de jure } \\
\text { communal or } \\
\text { private property) }\end{array}$ & $\begin{array}{l}\text { Reduced } \\
\text { (less rent } \\
\text { dissipation than } \\
\text { anarchy) }\end{array}$ & $\begin{array}{l}\text { Production of new land for allocation } \\
\text { Be lenient to squatting on state } \\
\text { properties and confer a degree of } \\
\text { rights and hence also obligations for } \\
\text { the use of land }\end{array}$ \\
\hline $\begin{array}{l}\text { Co-development } \\
\text { zoning } \\
\text { private property) }\end{array}$ & $\begin{array}{l}\text { Reduced } \\
\text { (fewer conflicts } \\
\text { and rent } \\
\text { dissipation by } \\
\text { conferring rights } \\
\text { to de facto } \\
\text { competitors } \\
\text { with the state) }\end{array}$ & $\begin{array}{l}\text { Should become the normal practice } \\
\text { for disputed territories instead of }\end{array}$ \\
\hline
\end{tabular}




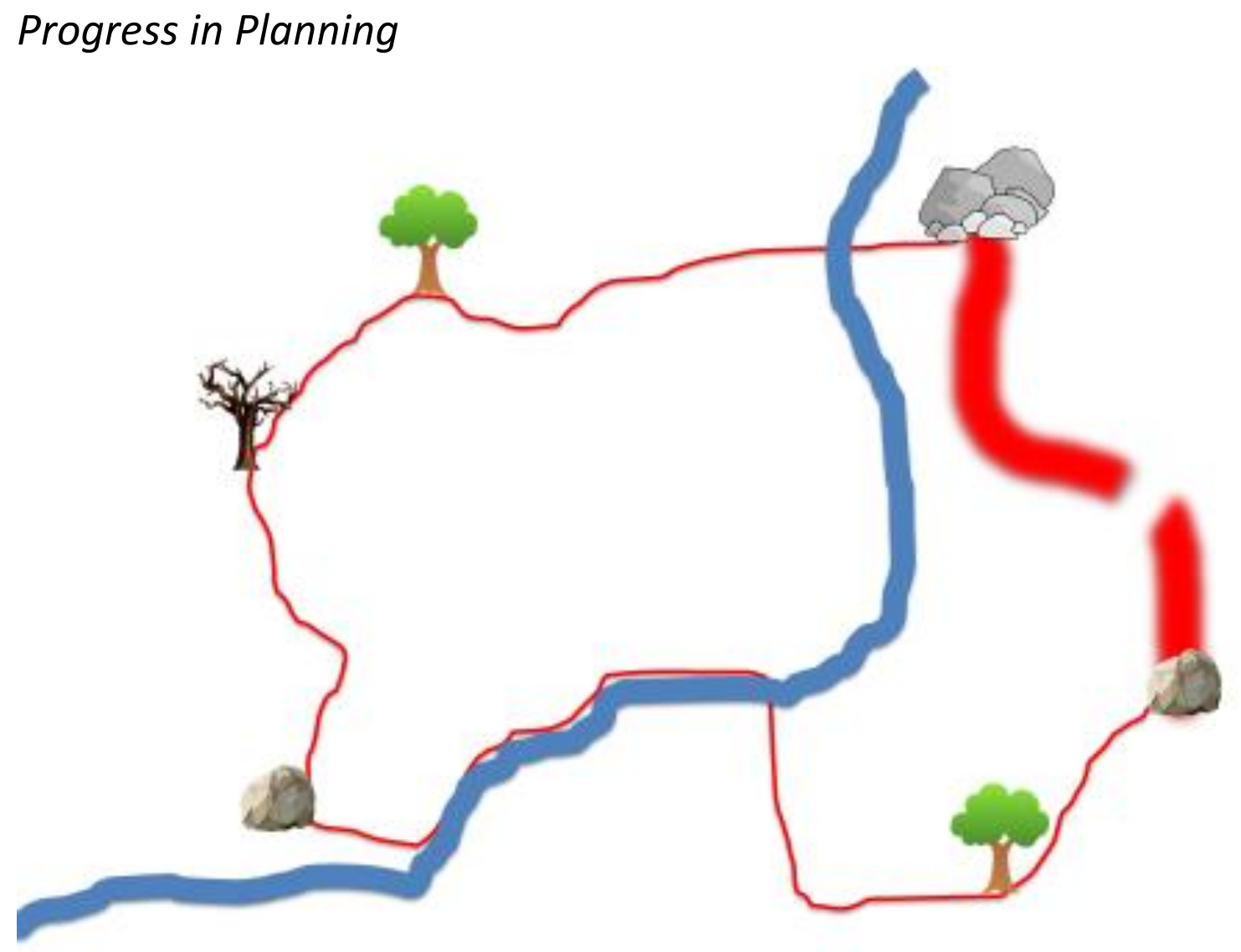

Figure 1A: Natural, Terrain Following Boundaries with Spatially Inexact Markers and with Eastern Boundary Indeterminate 


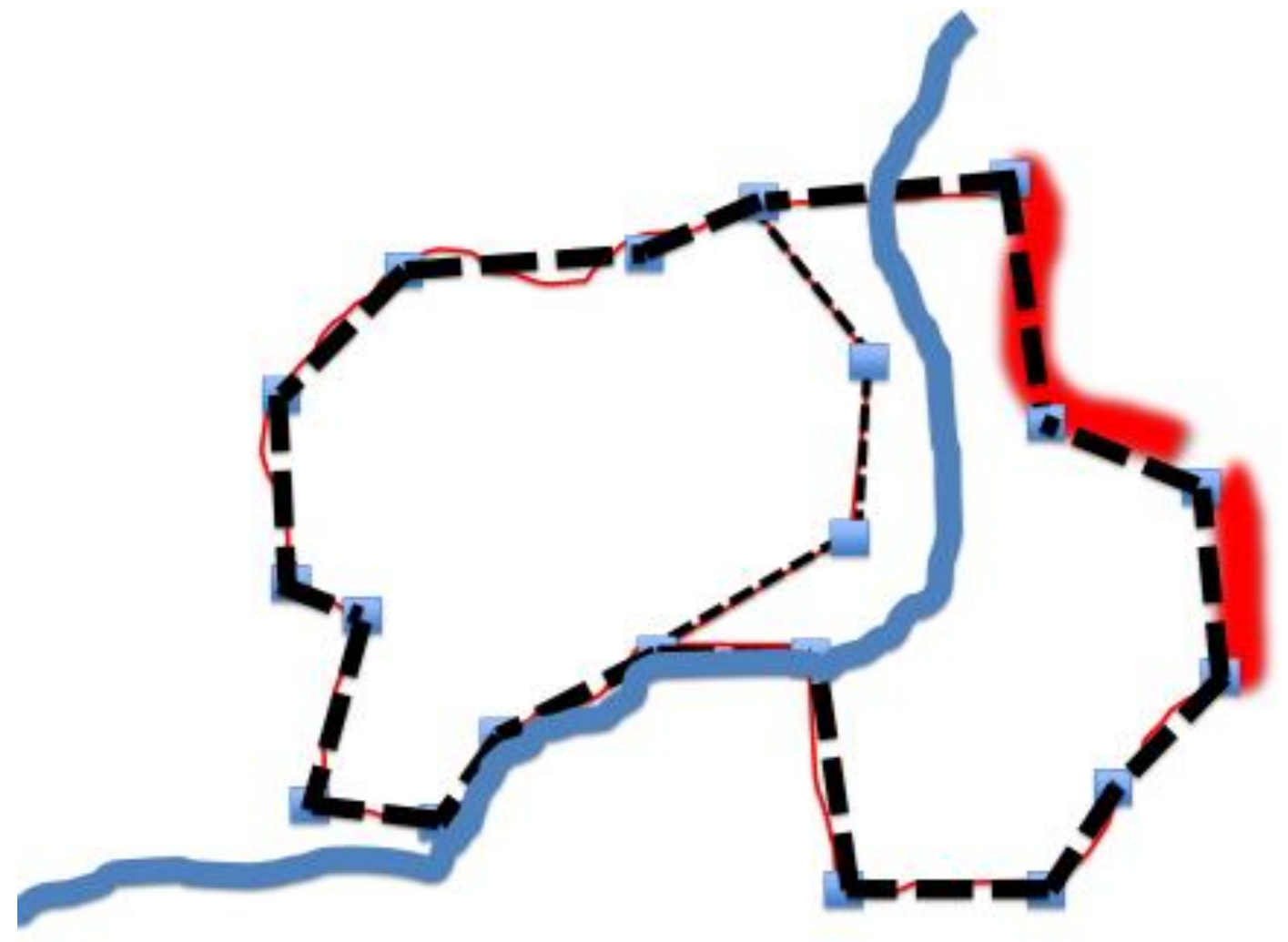

Figure 1B: The Same Bounded Territory with Superimposed, Surveyed Boundaries Rationalizing the Customary Boundaries and Removing the Indeterminacy of the Previous "Fuzzy" Eastern Boundary 
Progress in Planning

Figure 2A: The Coase Theorem

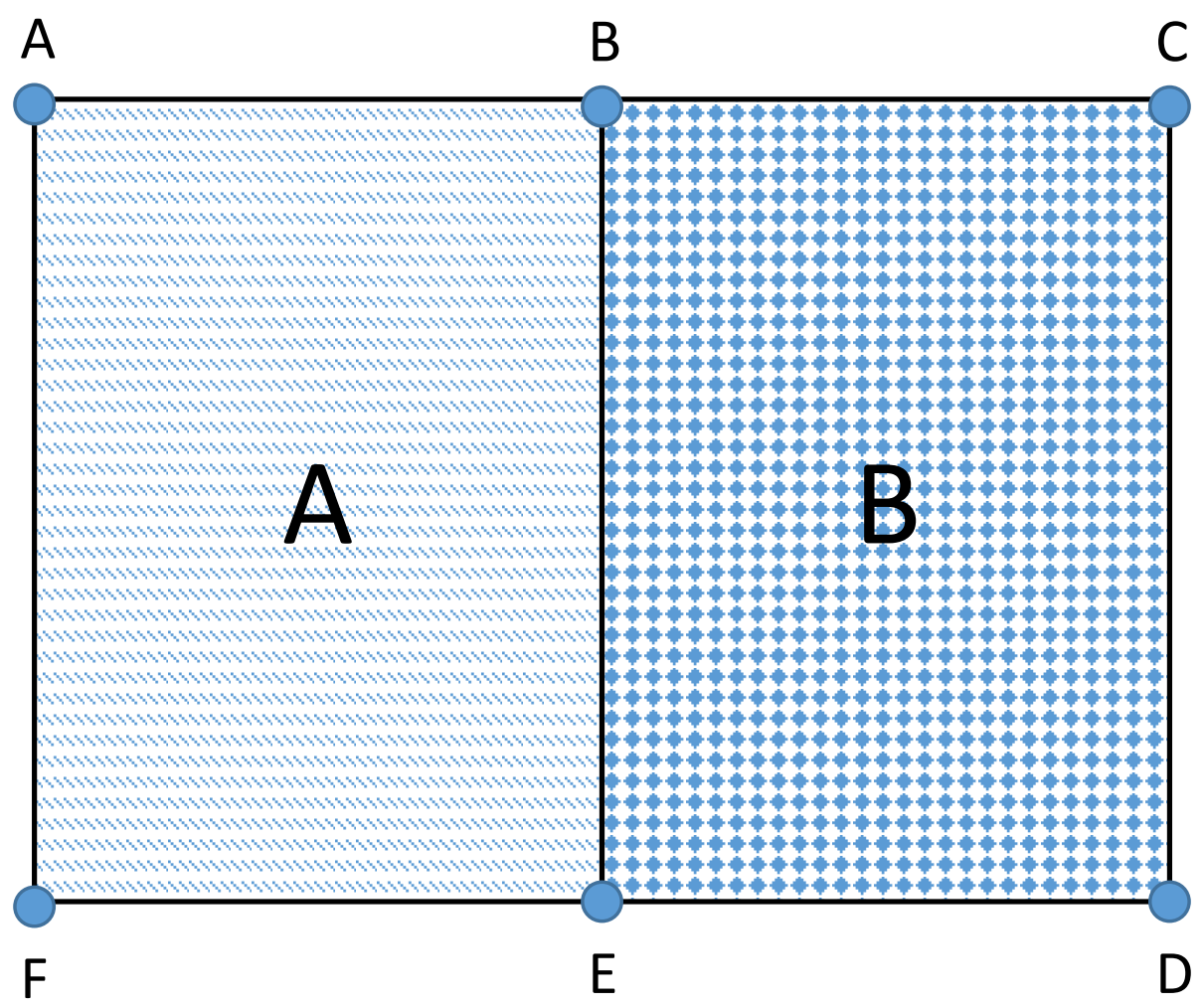

A

- Boundary point

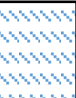

A's domain

$\%$

B's domain

Definitive boundary 
Figure 2B: The Corollary of the Coase Theorem

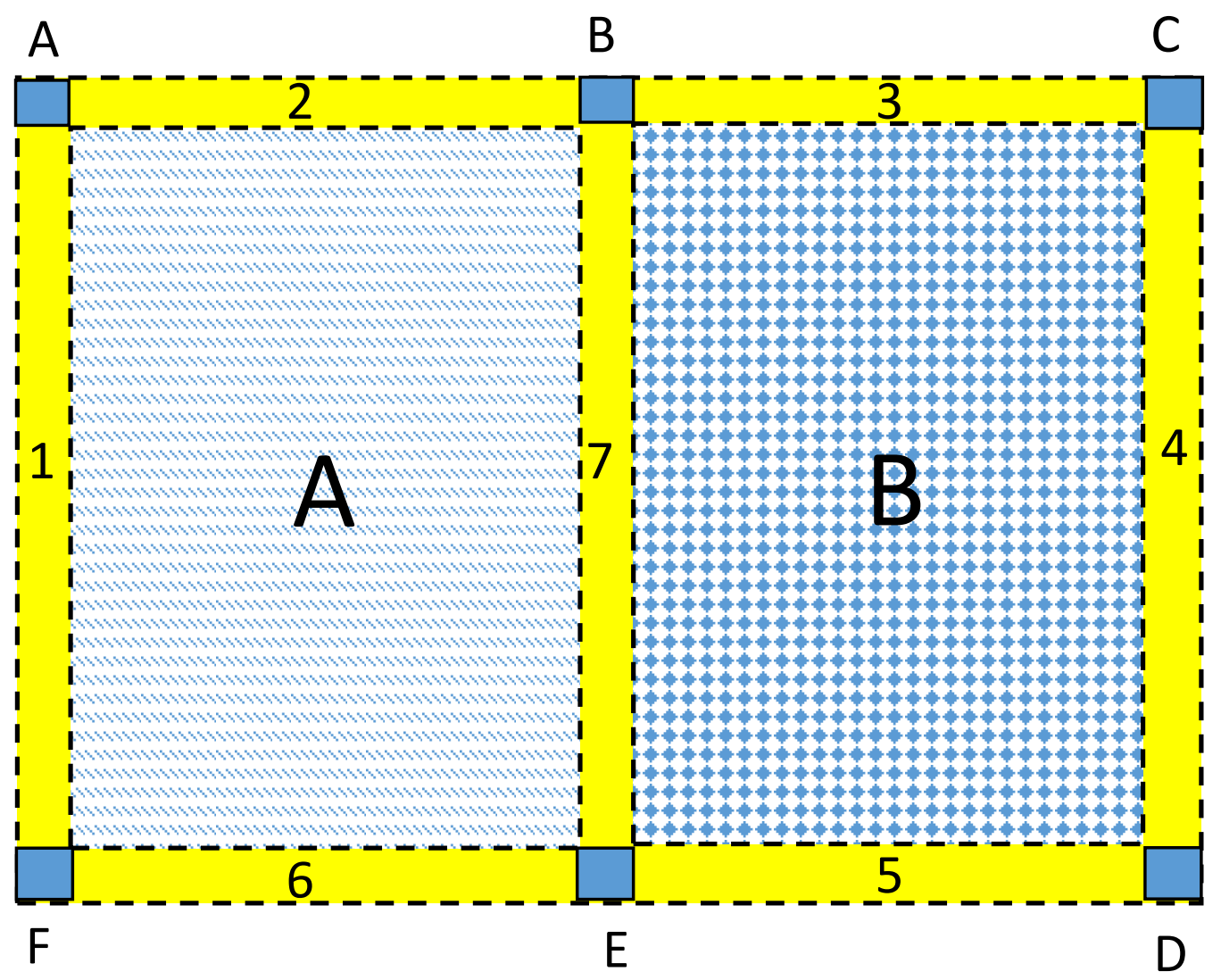

A

Boundary stone/landmark

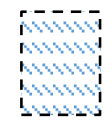

$A^{\prime}$ s domain

$17-7$

$1+4$

$1+4$

B's domain

$1-7$

Penumbra

Fuzzy boundary 
Progress in Planning

Figure 3: The Road Map of Lot 2 of Perth

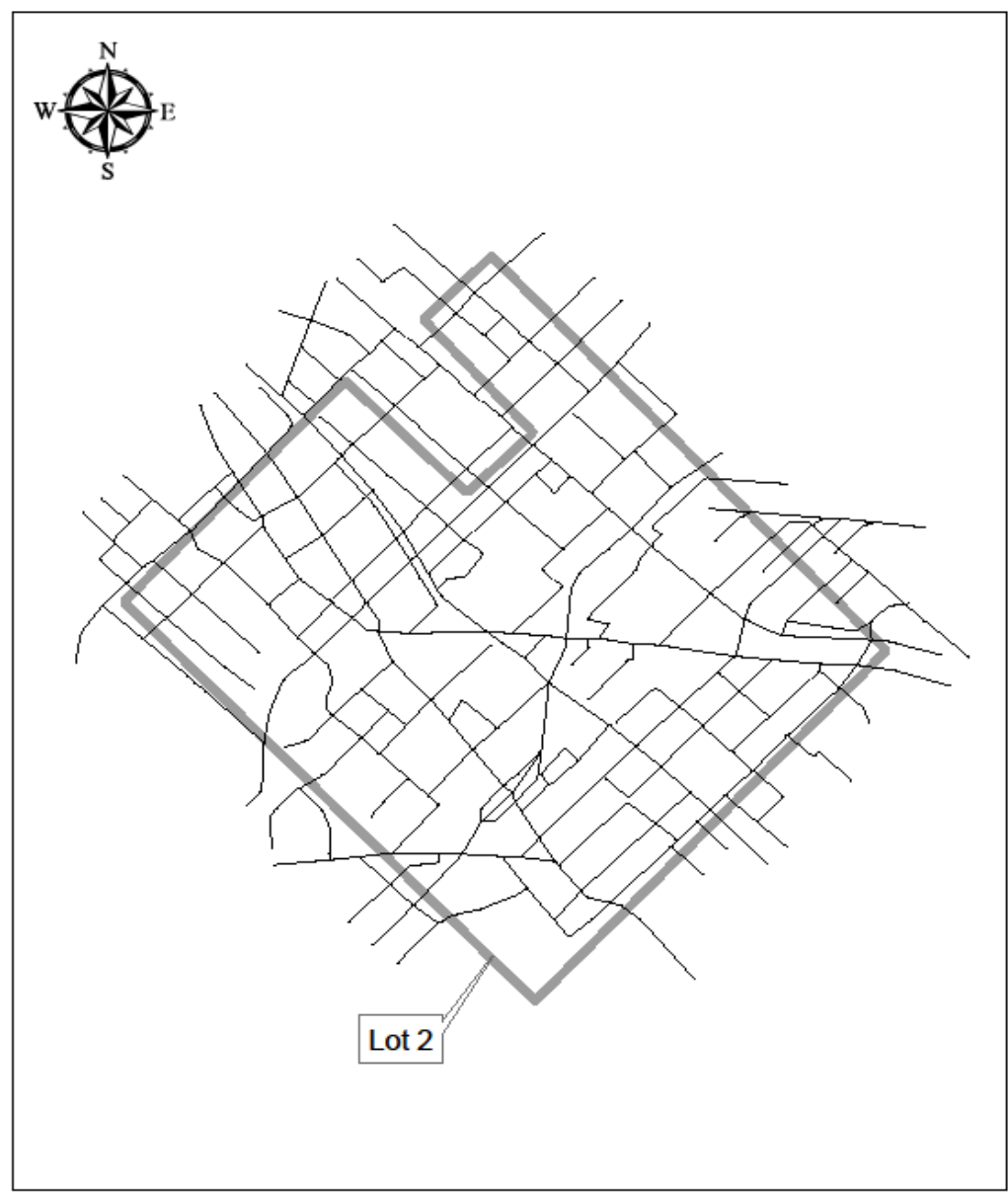

Road Map of Lot No.2

Legend:

Boundary of Lot No.2

Roads 
Progress in Planning

Figure 4A: The Coase Theorem in Action

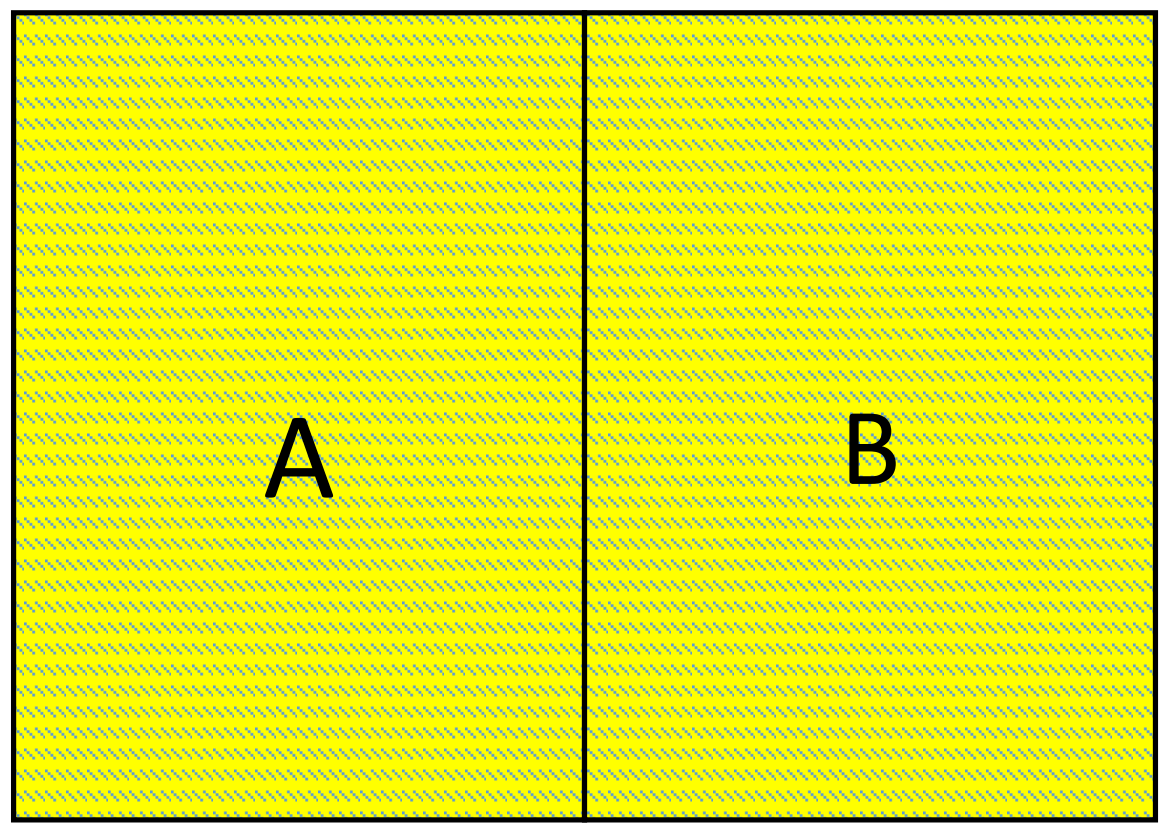

$A^{\prime}$ s domain

B's domain

Definitive boundary 
Figure 4B: The Corollary of the Coase Theorem in Action (without determination of common boundary)

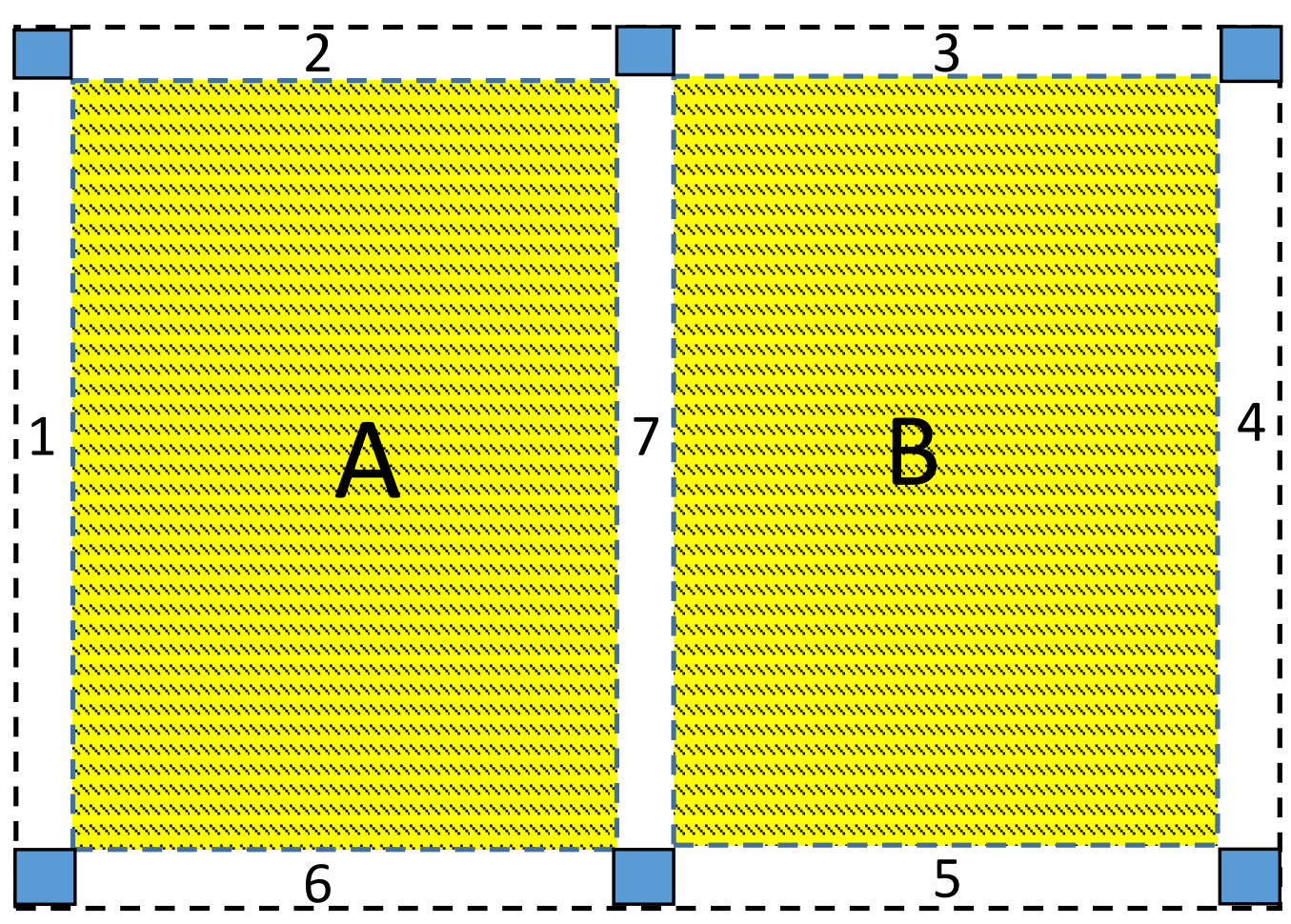

Boundary stone

$A^{\prime}$ s domain (privately negotiable area)

B's domain (privately negotiable area)

Penumbra

Fuzzy boundary 
Figure 4C: The Corollary of the Coase Theorem in Action (with state/court determination of common boundary)

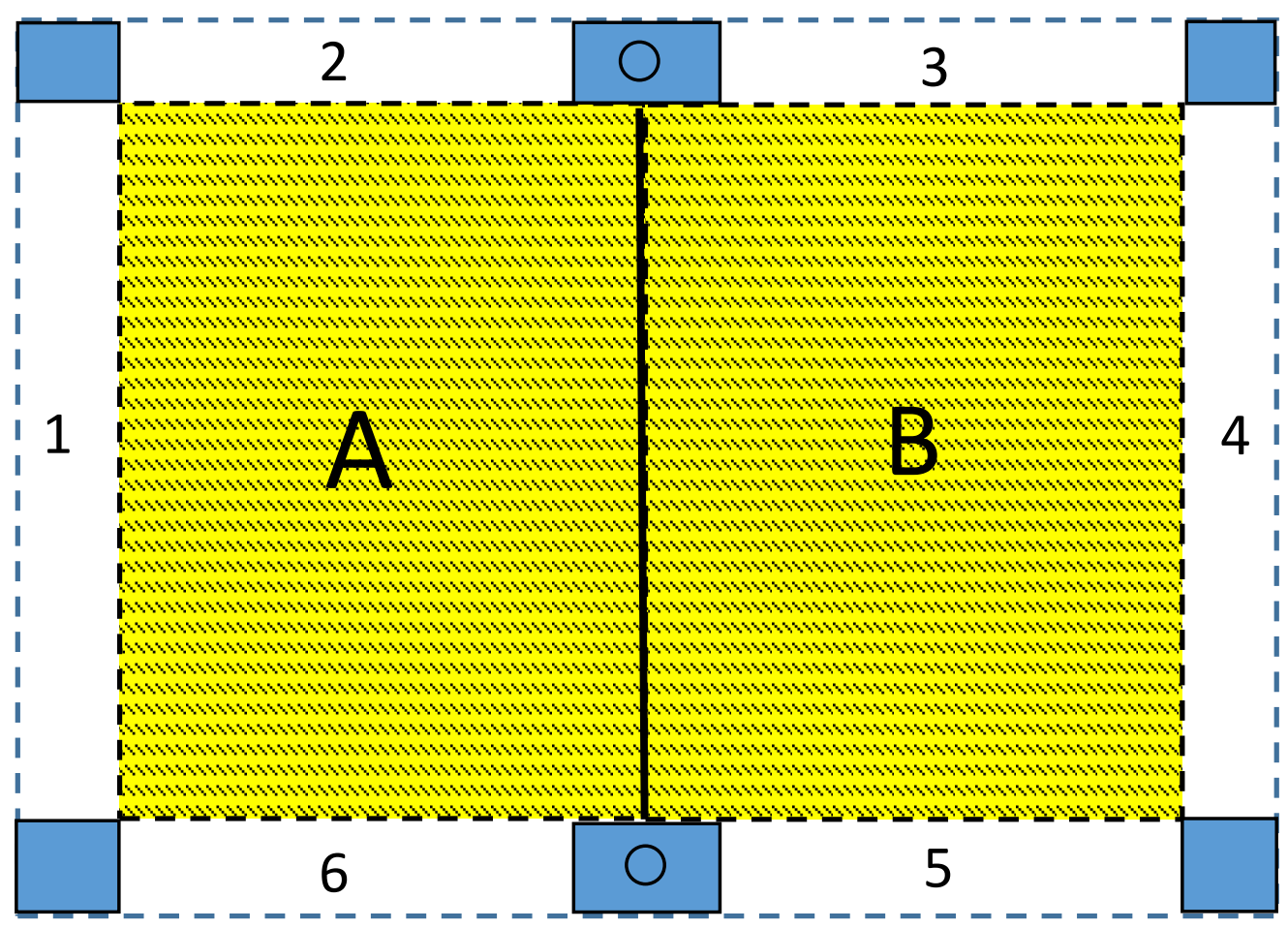

privately negotiable area

state/ court determined boundary point

$A^{\prime}$ s domain

$\mathrm{B}^{\prime}$ s domain

Penumbra

Fuzzy boundary 
Progress in Planning

Figure 5A: Conflict of Zoning (Forced Division)

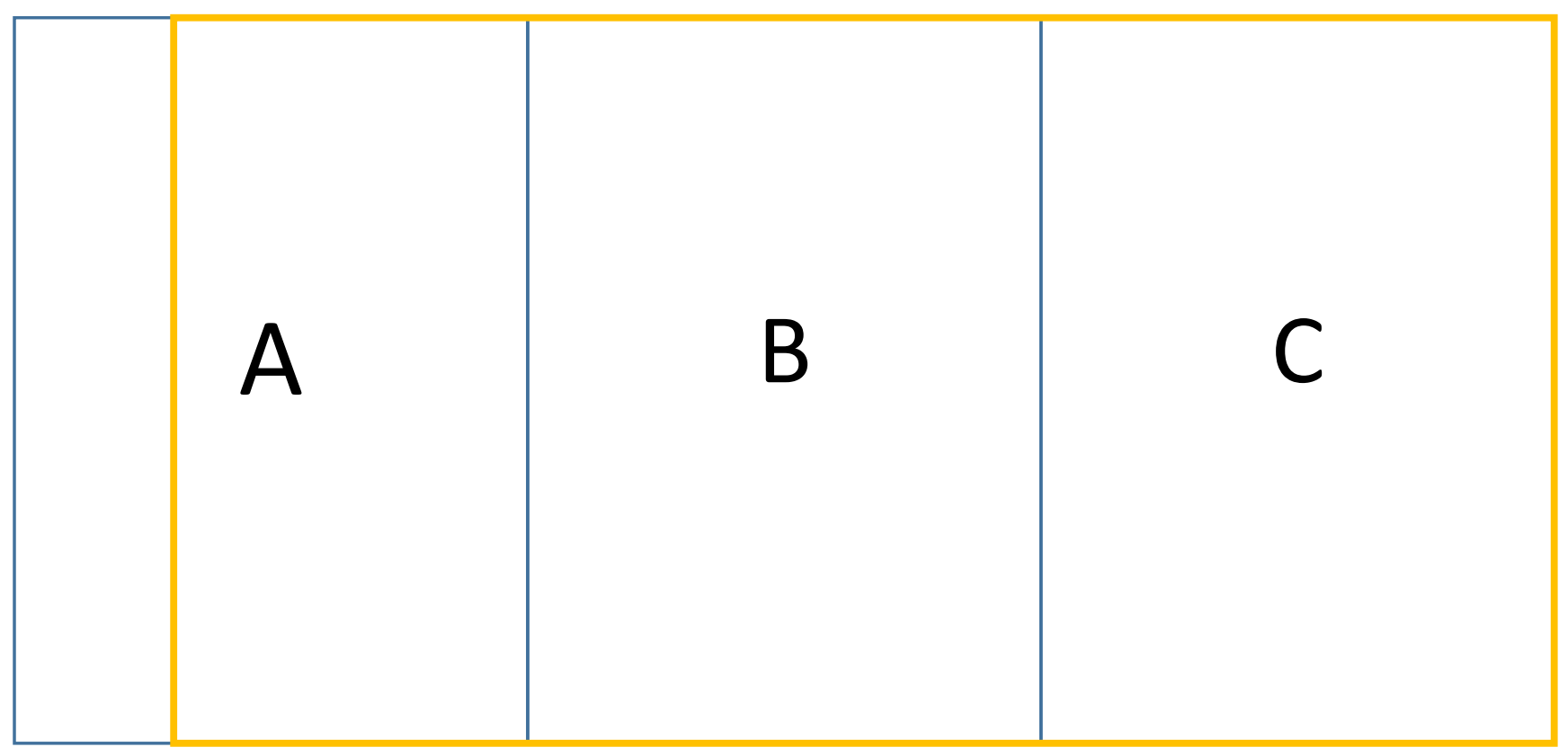

Lot Boundary

Imposed Zone 
Progress in Planning

Figure 5B: Conflict of Zoning (Forced Combination)

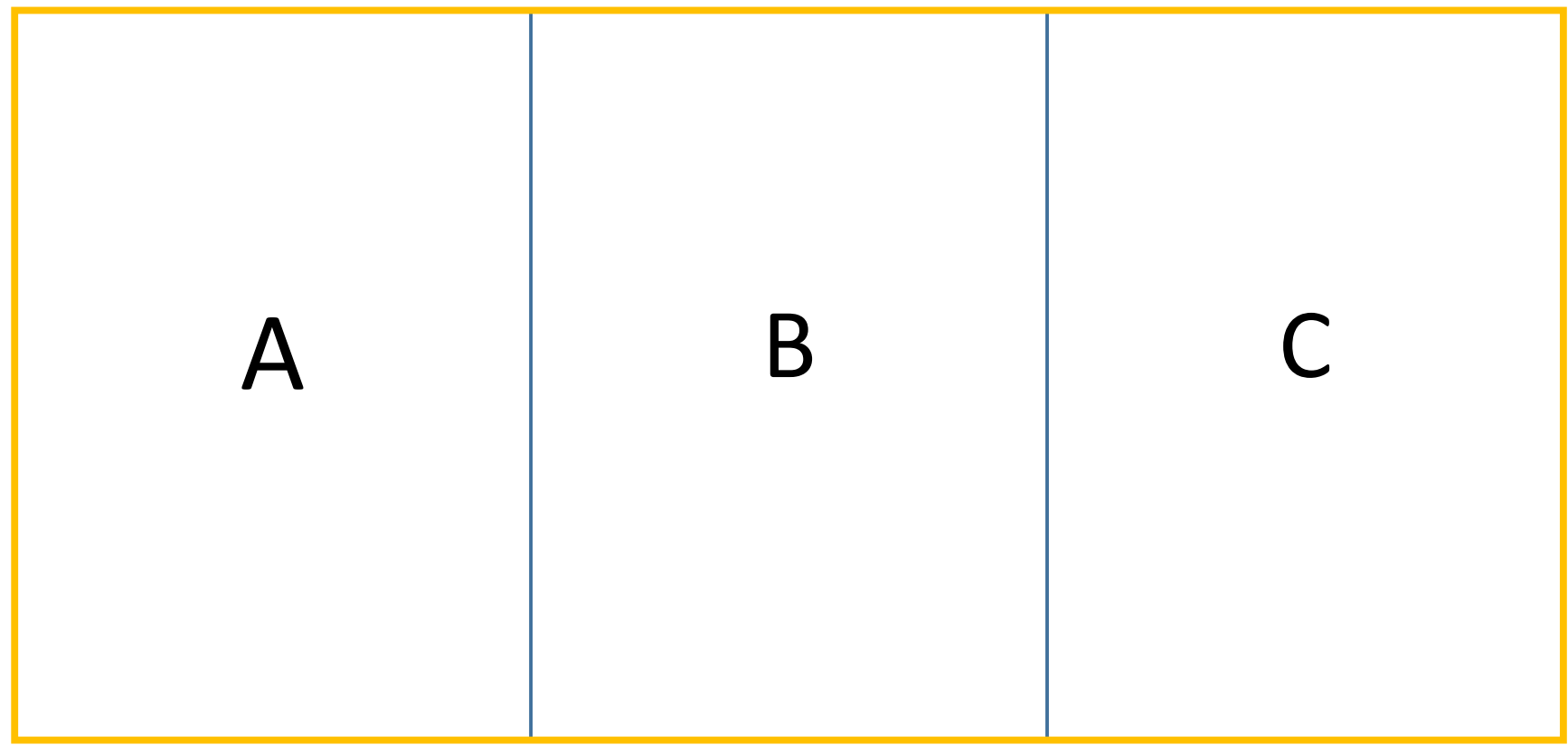

Lot Boundary

Imposed Zone wherein redevelopment by individual owners of $A, B$, and $C$ is disallowed 
Figure 6: Border Line Zoning

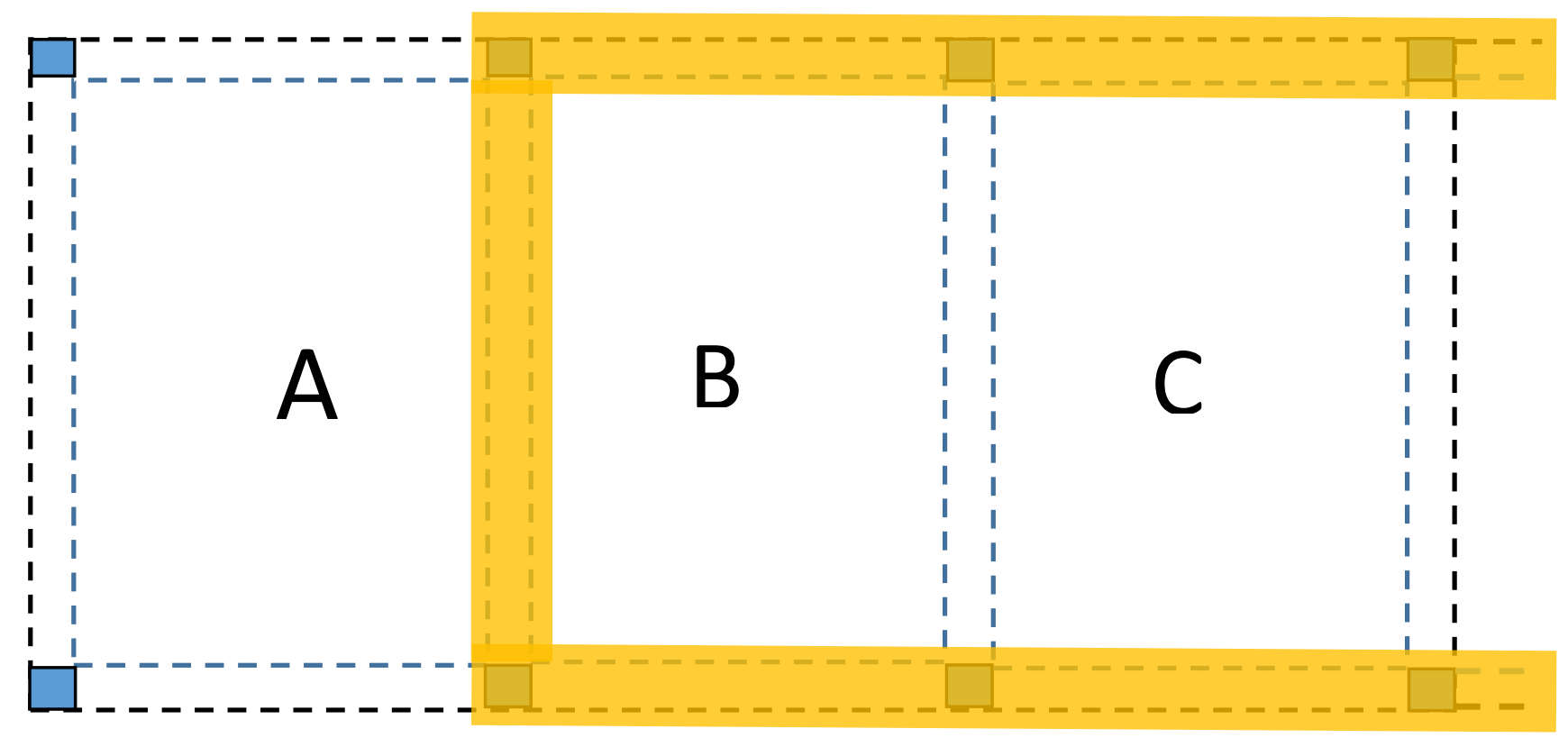

Landmark

- - : Fuzzy lot boundary

Zone boundary 
Figure 7: Incomplete Zoning

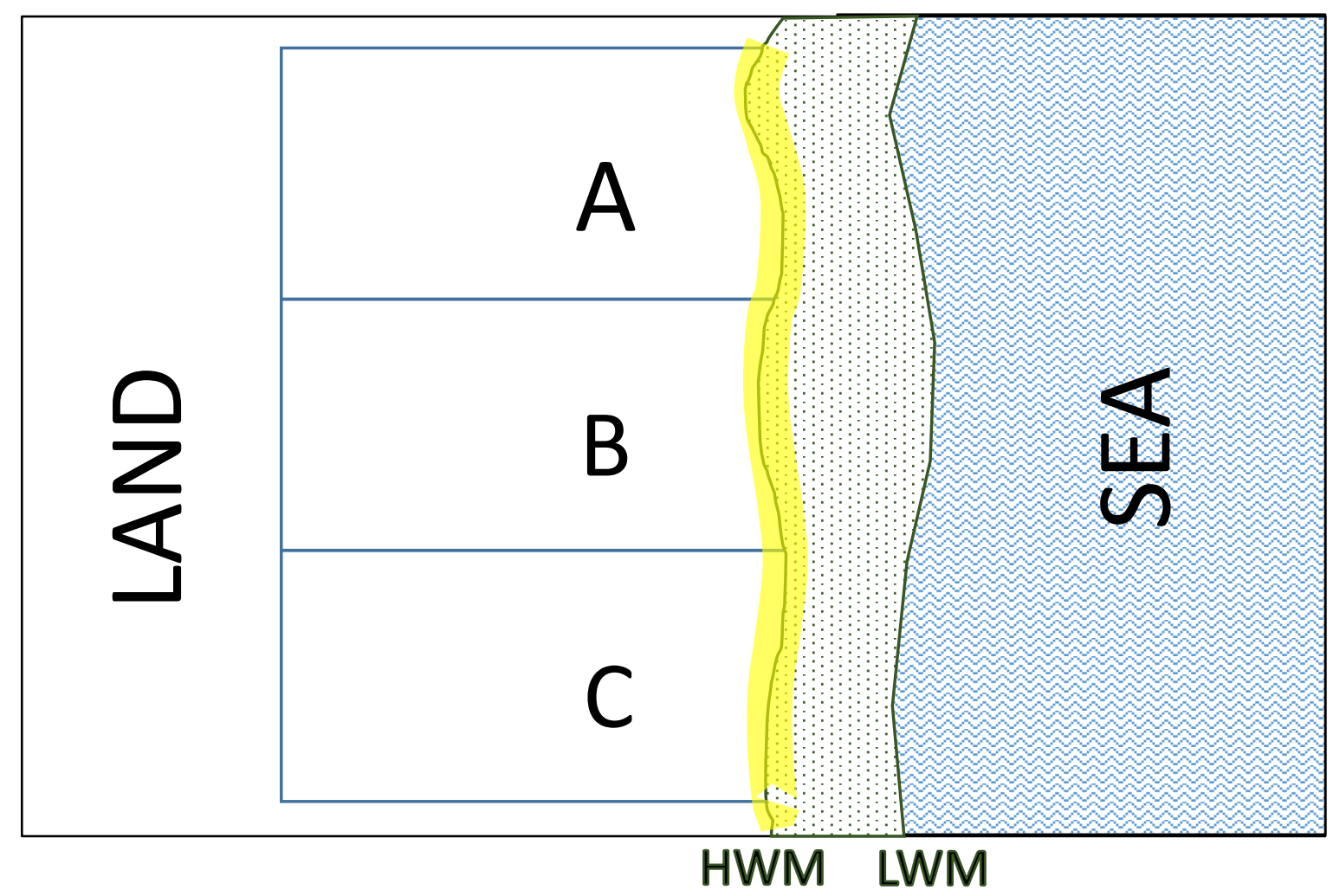

Definitive Land Boundary

HWM High Water Mark

LWM Low Water Mark 
Progress in Planning

Figure 8: Officially Forgotten Zone

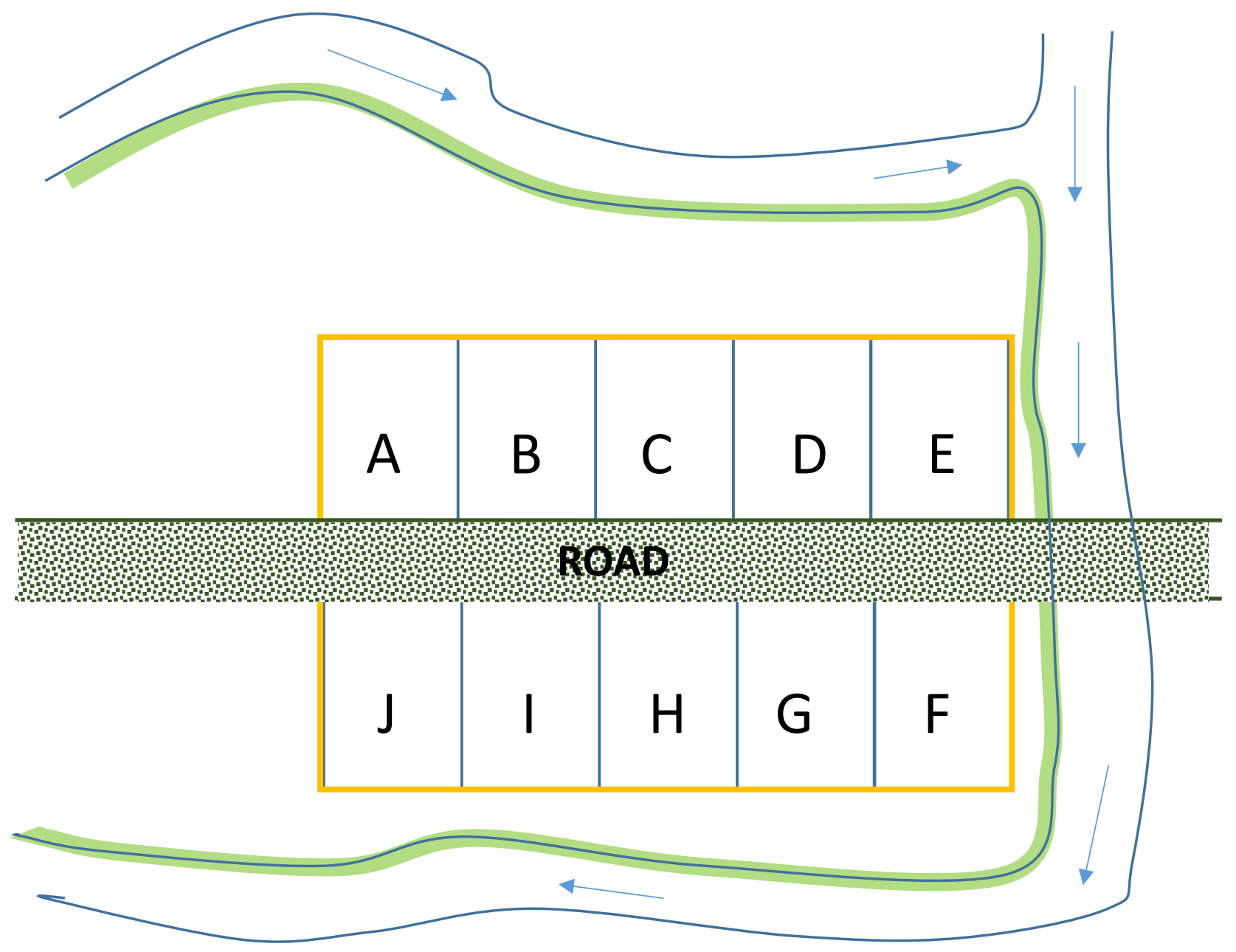

Lot Boundary

Imposed Zone

Officially forgotten tribal shrine 
Figure 8: Zoning for Non-planning

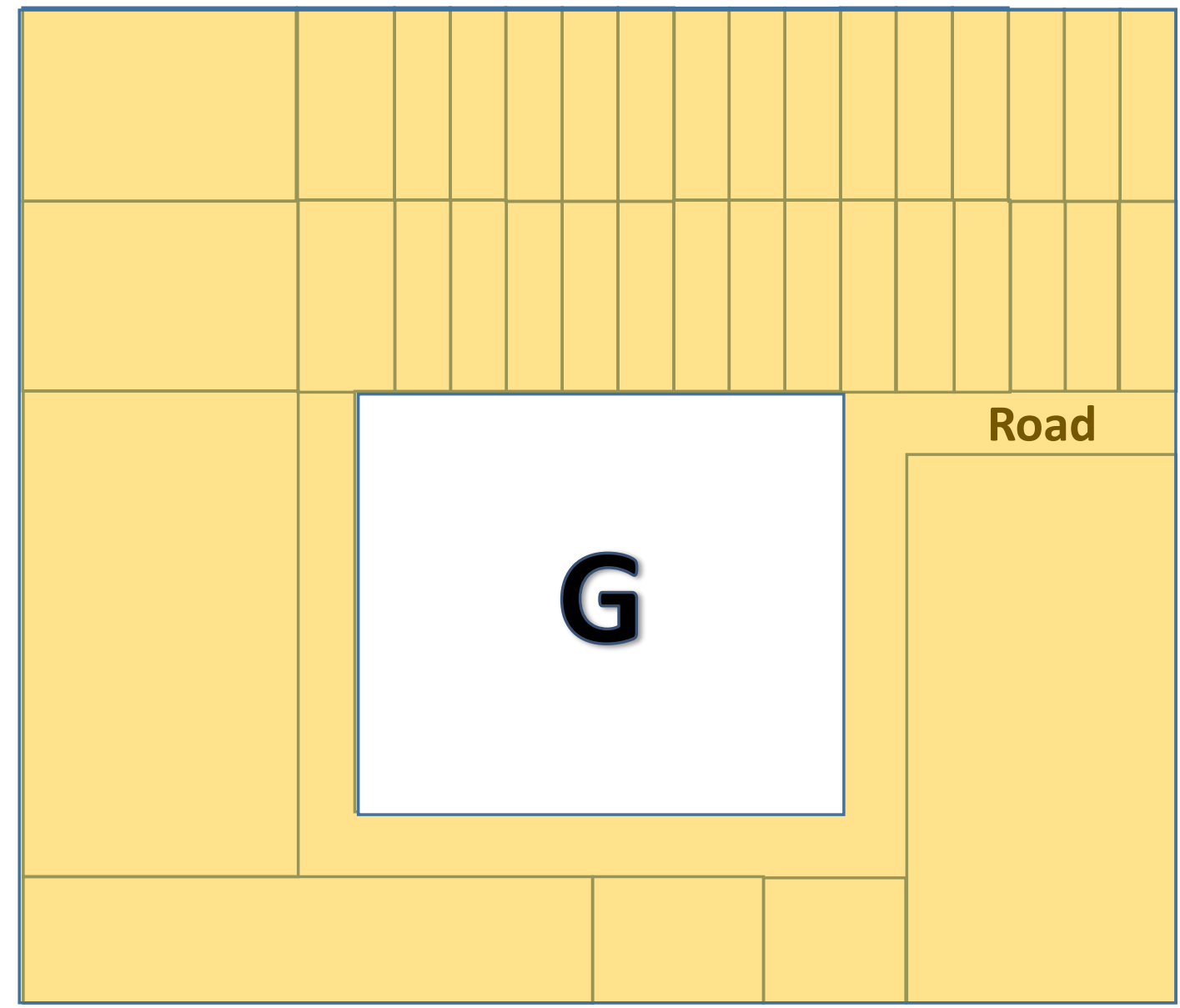

Lot Boundary

Imposed Zoning

G

Ghetto 
Progress in Planning

Figure 10: Rights Conferring Zoning

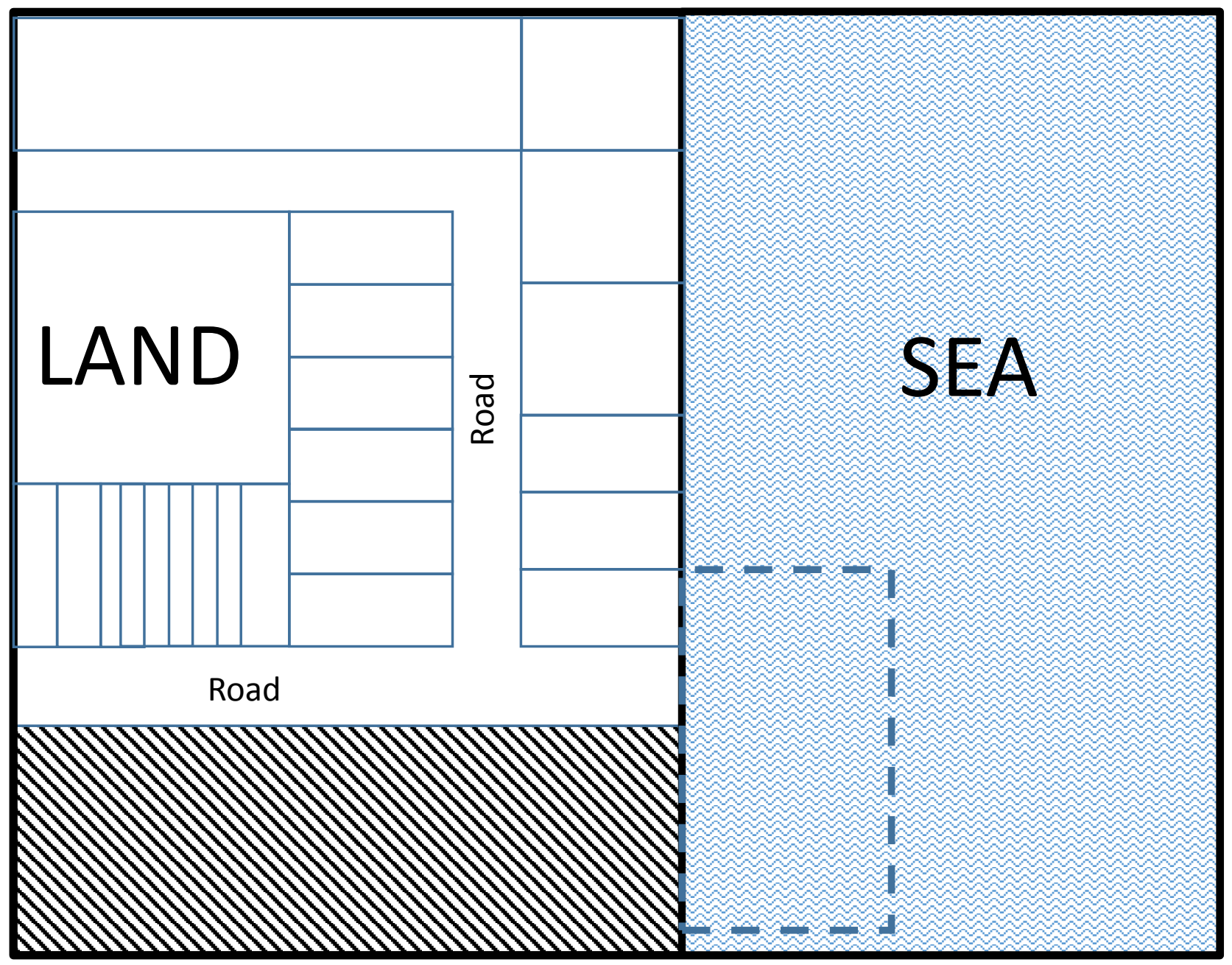

Lot Boundary

$n^{-1}$

ᄂ 」Lot Boundary (land created by reclamation of the sea)

M

Land created by hillside terracing, earth excavated used to reclaim land from the sea 
Figure 11: Co-development Zone

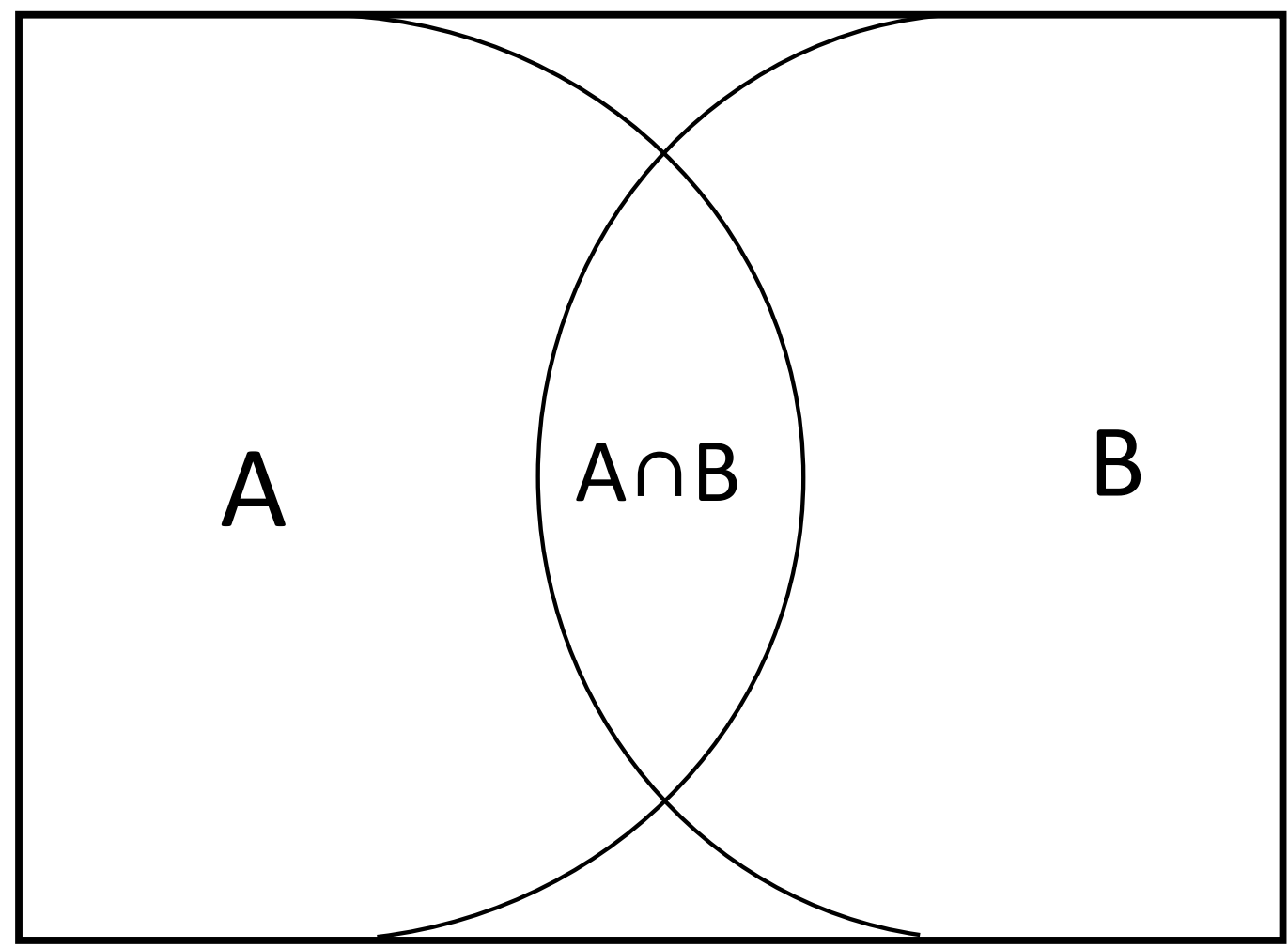

)

De jure boundary claimed

\section{$A \cap B$}

Co-development zone, can be governed by a body corporately formed by owners of $A$ and $B$ 
Progress in Planning

Figure 12: Expansion of Coasian Negotiable Domain
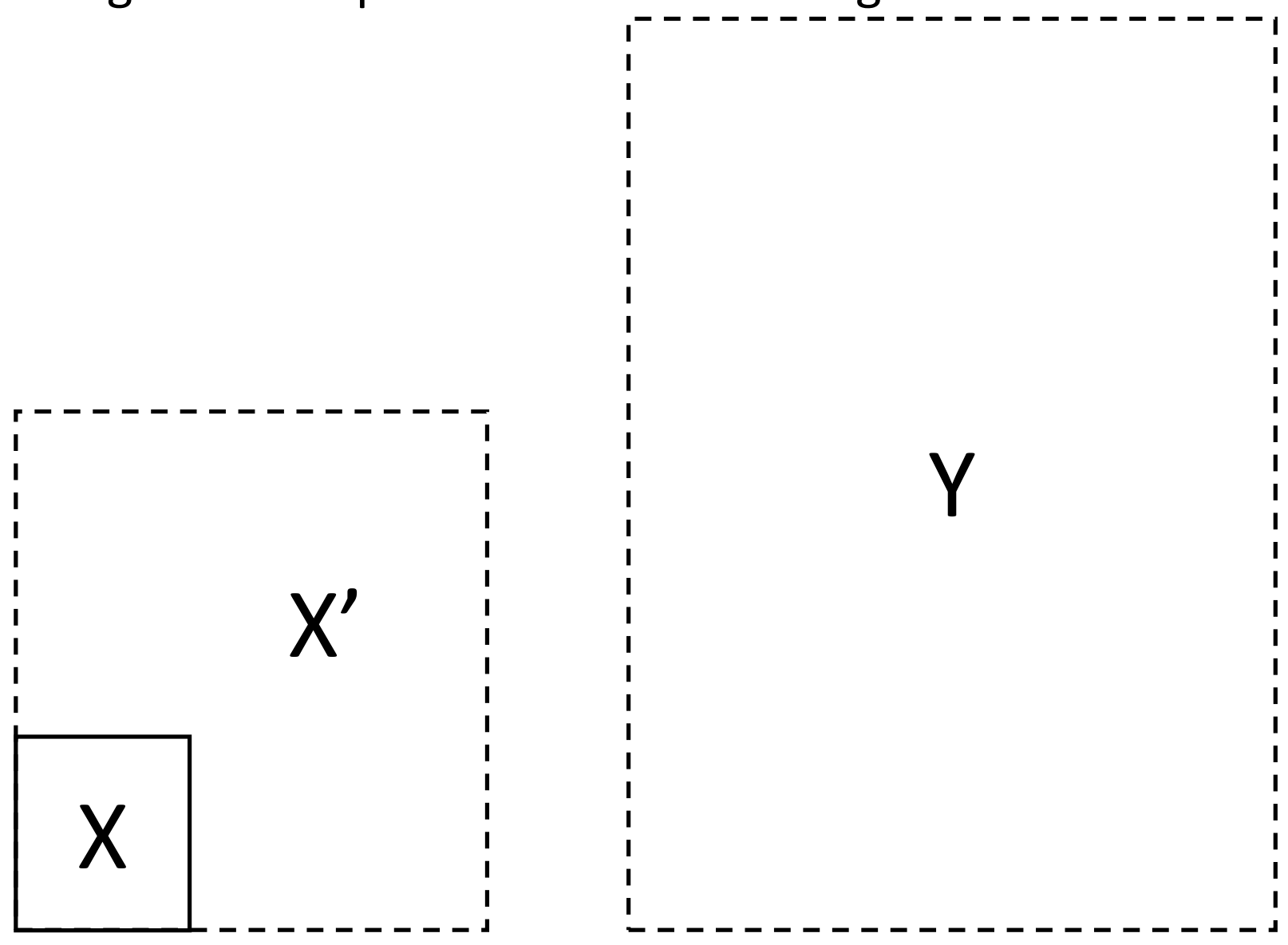

$\mathbf{X}$ Original domain

$X^{\prime}$ New frontier

Y New plantation

--- Fuzzy boundary 
Progress in Planning 